Andrews University

Digital Commons @ Andrews University

2011

\title{
A Model Course for Training Lay Persons of the Chicago Area in Biblical Preaching
}

Leeroy M. Coleman

Andrews University

Follow this and additional works at: https://digitalcommons.andrews.edu/dmin

Part of the Practical Theology Commons

\section{Recommended Citation}

Coleman, Leeroy M., "A Model Course for Training Lay Persons of the Chicago Area in Biblical Preaching" (2011). Professional Dissertations DMin. 594.

https://dx.doi.org/10.32597/dmin/594

https://digitalcommons.andrews.edu/dmin/594

This Project Report is brought to you for free and open access by the Graduate Research at Digital Commons @ Andrews University. It has been accepted for inclusion in Professional Dissertations DMin by an authorized administrator of Digital Commons @ Andrews University. For more information, please contact repository@andrews.edu. 


\begin{abstract}
A MODEL COURSE FOR TRAINING LAY PERSONS OF THE CHICAGO AREA IN BIBLICAL PREACHING
\end{abstract}

by

Leeroy M. Coleman

Adviser: James North 


\section{ABSTRACT OF GRADUATE STUDENT RESEARCH \\ Project Dissertation}

Andrews University

Seventh-day Adventist Theological Seminary

\section{Title: A MODEL COURSE FOR TRAINING LAY PERSONS OF THE CHICAGO AREA IN BIBLICAL PREACHING}

Name of researcher: Leeroy M. Coleman

Name and degree of faculty adviser: James North, D.Min.

Date completed: June 2011

\section{Problem}

The Scriptures, both Old and New Testaments, speak of the importance of preaching. The Christian Church of today places a high priority on preaching, but the burden is shouldered mainly by the clergy with little participation by the laity. The OT and the NT demonstrate the importance of clergy and laity sharing in the ministry of preaching, but today pastors need lay persons to preach and lay persons express their need to be trained in preaching. There is a dirth of materials and programs that will 'effectively train lay persons to preach. It was task this project to develop an effective program to train lay person in the Chicago area to preach. 


\section{Method}

A preaching program was designed and developed over a four-year period to teach lay persons in the Chicago area to preach. The program offered a cycle of courses that allowed students to develop and grow in the academic and practical aspects of preaching. The first course was taught over a nine-month period, while the other courses covered a ten-week period. Students could enroll for one course or could take other courses in the preaching program. Each course offered lectures, presentations, preaching drills, class exercises, sermons to be preached in class, an exam and a graduation ceremony.

Evaluation was done using a variety of instruments. A pre-course evaluation form, a post-course evaluation form, a sermon evaluation form for the audience to evaluate the student, a sermon evaluation form for class to evaluate student preachers, an instructor evaluation form, a personal evaluation form for each student to evaluate themselves, a course evaluation form for instructors to use, and a focus-group session to evaluate and reflect on the course.

Results

A total of 76 students enrolled in the courses, and 51 graduated from the preaching program of a four-year period. Both course attendees and graduates gave high ratings for the course, structure, content, methods, teaching, and instructors. Church members and other pastors who experienced the preaching of students gave favorable ratings to the sermons and noted improvements of lay preachers. Evaluation of this project gives focus to the need for more training programs, a larger and wider territory of lay persons to be reached and trained for the preaching ministry, need for pastors to be 
exposed and also trained to train lay persons to preach, and for the larger organization to collaborate with pastors and lay persons to formulate a plan to do more training of lay persons across the North American Division of Seventh-day Adventists Church.

\section{Conclusions}

This project demonstrated that the need for training lay persons to preach is a significant one for churches, pastors, lay persons and the larger church organization. A model training course for laypersons did show itself to be: 1) a valuable resource for pastors to use to equipped lay persons for the preaching ministry, 2) a valuable source of educating and training lay persons to preach in Chicago area churches-improving their preaching skills and motivating them for more involvement in ministry, 3) a useful tool to helping the larger church organization be more intentional in how it trains lay persons in many areas of ministry, especially for the future development of lay preachers.

Lay persons were motivated to participate, felt a need to be trained, and wanted to partner with the professional clergy in the preaching ministry to fulfill the gospel commission of Jesus. 
Andrews University

Seventh-day Theological Seminary

\begin{abstract}
A MODEL COURSE FOR TRAINING LAY PERSONS
OF THE CHICAGO AREA IN BIBLICAL PREACHING
\end{abstract}

\author{
A Project Dissertation \\ Presented in Partial Fulfillment \\ of the Requirements for the Degree \\ Doctor of Ministry
}

by

Leeroy M. Coleman

June 2011 
(C) Copyright by Leeroy M. Coleman 2011

All Rights Reserved 


\title{
A MODEL COURSE FOR TRAINING LAY PERSONS \\ OF THE CHICAGO AREA IN BIBLICAL PREACHING
}

\author{
A project dissertation \\ presented in partial fulfillment \\ of the requirements for the degree
}

Doctor of Ministry

by

Leeroy M. Coleman

APPROVAL BY THE COMMITTEE:

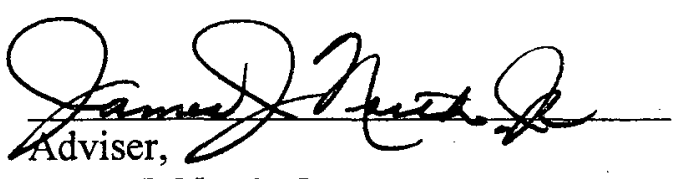

James J. North, Jr.
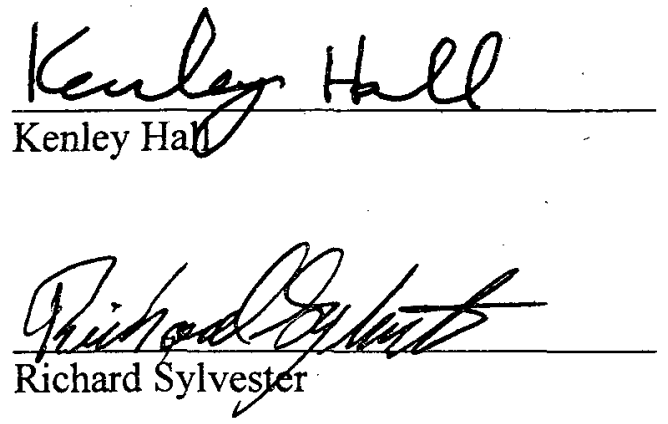
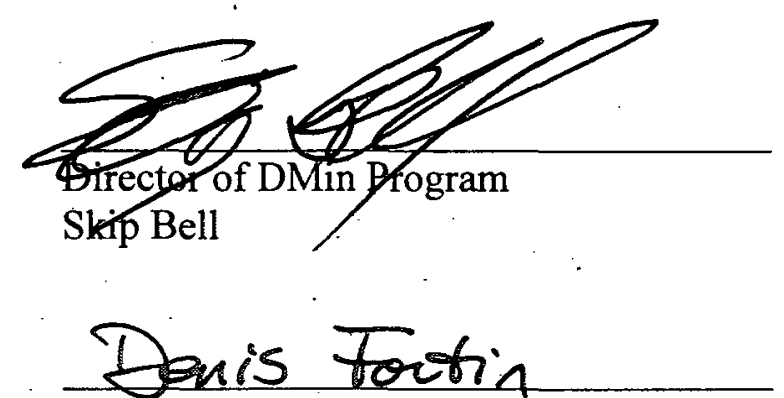

Dean, SDA Theological Seminary

Denis Fortin

\section{Peember 2012}

Date approved 


\section{TABLE OF CONTENTS}

LIST OF TABLES

Chapter

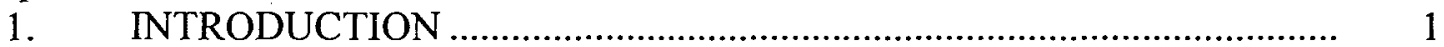

The Problem ..........................................................................................

Statement of Task .......................................................................... 3

Methodology ....................................................................... 3

Justification ................................................................................. 4

A Case Study as an Illustration of the Problem ................................... 7

The Theoretical and Theological Positions............................................. 8

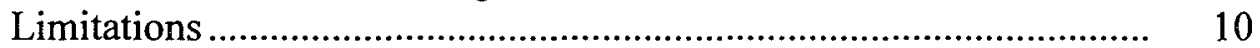

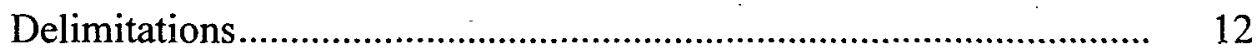

Expectations............................................... 13

Definitions of Major Terms ............................................................. 15

Area of Study ............................................................................... 17

Overview of the Dissertation ............................................................. 18

2. FOUNDATIONS FOR TRAINING LAY PERSONS TO PREACH........ 21

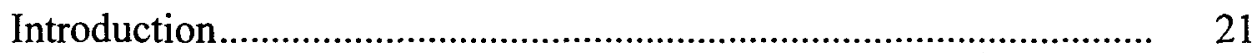

OT Biblical Foundations for Training Lay Preachers.......................... $\quad 21$

OT Biblical Terminology for Lay Preaching …….............................. 23

NT Biblical Foundations for Training Lay Preachers.............. . $\quad 40$

NT Biblical Terminology for Lay Preaching...................................... $\quad 42$

Jesus' Model for Training Lay Preachers ............................................. 48

Notable NT Lay Preachers.................................................................. 52

John the Baptist..................................................................... 52

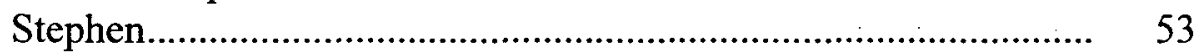

The Apostles ..................................................................... 54

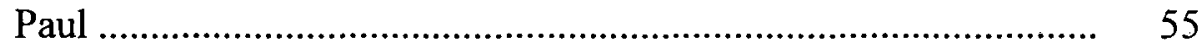

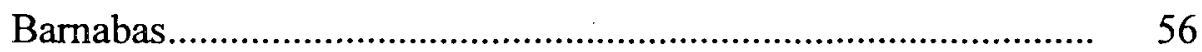

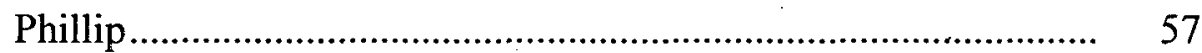

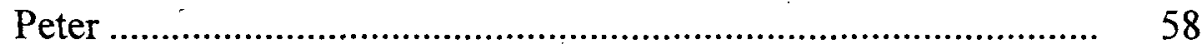

Women Lay Preachers ...................................................................... 59

New Testament Summary ............................................................. 62

Chapter Summary and Conclusions ................................................... 63 
Foundation for Lay Preaching in Christian Literature ......................... 65

Post Early Church Era........................................................................ 65

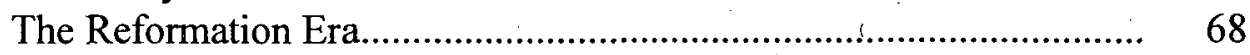

Post Reformation/Nineteenth Century ................................................ 71

Twentieth and Twenty First Centuries................................................. $\quad 71$

Separation of Laity from Preaching ....................................................... 73

Foundations for Training Lay Preachers in Current

Literature Review.

Foundations for Training Lay Preachers in the Writings of Ellen G. White

A Brief Historical Sketch ................................................................. 93

Concept of the Role of Laymen in Ministry .................................. 93

Differentiation of Pastoral and Lay Preaching............................... 94

Concept of Training Lay Persons to Preach .................................. 95

Partnership of Clergy and Laity for Ministry .............................. 98

Summary ...................................................................................... 101

4. A MODEL TO TRAIN LAY PERSONS TO PREACH …….................... 104

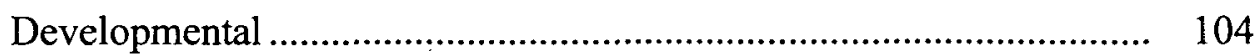

Foundations of This Developed Model.......................................... 104

Development of the Training Model............................................. 107

Application of Real-Time Ministry/Lay Class Setting .................. 109

Implementation - Process of Progression ............................................ 110

Project Development............................................................. 110

Project Application .................................................................. 111

Team of Instructors ...................................................................... 112

The First Year Preaching Model .................................................... 112

The Second Year Preaching Model ............................................... 113

The Third Year Preaching Model ............................................... 114

The Fourth Year Preaching Model ............................................... 114

Class Session and Lesson Plans ................................................ 116

Course Commentary and Notes ........................................................ 116

Session Plan and Lesson Subjects/Titles ........................................... 121

On-Going Training for Lay Preachers ............................................... 124

The Coaching Component …...................................................... 125

The Mentoring Principle .............................................................. 126

Principles of Adult Education ....................................................... 127

In Touch With Needs and Requirements ..................................... 127

Guided Instruction for Present and Future Competency............... 130

Motivators and Motivation Principles ......................................... 131

Effective Adult Instructors Use Effective Elements..................... 132

Application of Coaching Practice in Ministry .................................. 133

One-on-One Mentoring............................................................ 134 
Student Groups and Preaching Partners........................................ 134

Semi-Annual Preaching Workshop-Gatherings............................ 135

Seven-Step Process ........................................................................ 136

5. EVALUATION OF THE PROJECT .................................................. 139

Students Evaluate the Course........................................................... 139

Survey of Lay Persons' Preaching Experience ............................. 140

Course Evaluation ......................................................................... 141

Audience Evaluation of Lay Sermon: Post-Sermon Survey.......... 143

Coaching Component Evaluation ................................................ 144

Focus Group's Evaluation of the Preaching Course ...................... 146

Evaluation Summary .................................................................... 149

6. SUMMARY, CONCLUSIONS AND RECOMMENDATIONS .............. 151

Summary .............................................................................. 151

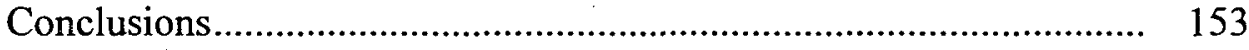

Recommendations...................................................................... 154

Appendix

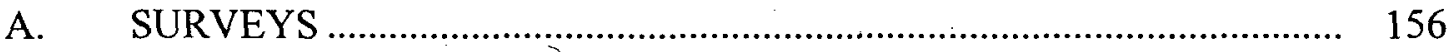

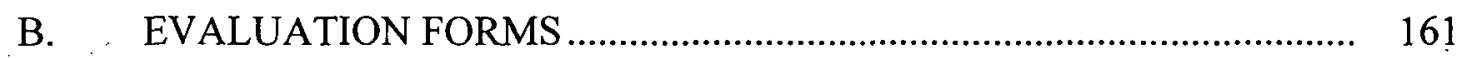

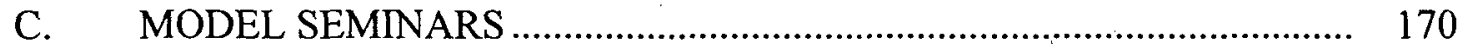

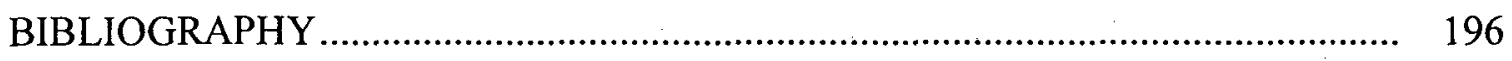

VITA 


\section{LIST OF TABLES}

1. Two-Year Cycle Model Preaching Course ......................................................... 114

2. Lay Preaching Program Trends ..................................................................... 120

3. Summary Chart for Different Adult Ways of Knowing ....................................... 129

4. A Comparison of Pedagogy and Andragogy ..................................................... 131 


\section{CHAPTER ONE}

\section{INTRODUCTION}

\section{The Problem}

Preaching, the proclamation of the gospel-good news, is the God-given responsibility of lay persons and clergy. Pastors, churches, and conferences in metropolitan Chicago need more trained preachers among the laity. This need has long existed and has not been addressed or solved by any known plan or ministry strategy. Consequently the need just keeps getting greater. Therefore, in addition to the training of full-time pastors and evangelists, God's church should continue to train lay persons to preach the Word. Floyd Bresee, a veteran pastor and lay training specialist, observes that we should give high priority to preaching because, "it was central to His (Jesus') own ministry." He further highlights: "Preaching, or proclaiming, is mentioned three times in His Nazareth sermon where He lays out His methods of ministry, 'The Spirit of the Lord is upon me, because he hath anointed me to preach the gospel to the poor; to preach deliverance to the captives, to preach the acceptable year of the Lord" $"$ If preaching is central to Jesus' ministry and we are to "go ye therefore, and make disciples. ...

${ }^{1}$ W. Floyd Bresee, Successful Lay Preaching (Silver Springs, MD: Ministerial Association, General Conference of Seventh-day Adventists, 1997), 11.

${ }^{2}$ Luke 4:18, 19 (NIV). 
Teaching them to observe all things whatsoever I have commanded you,"3 then training discipleș-lay persons to preach, a central aspect of Jesus' ministry, is absolutely urgent for God's church.

God's remnant church faces many challenges as never before. Around the world the Seventh-day Adventist Church is exploding in growth. This growth brings about increasing responsibilities and workloạd on church leaders. Pastors in the North American Division of Seventh-day Adventists face a trend of managing larger districts. With large districts and more congregations, many pastors are unable to be in two places (three or four, for that matter) each Sabbath. Lay leaders have to be trained to help with pastoral responsibilities. Lay preachers, even in North America-where we have an ample supply of clergy, occupy the majority of Seventh-day Adventist pulpits each Sabbath. Some congregations hear a lay preacher at 50 to 75 percent of Sabbath services. ${ }^{4}$ Church leader and teacher, Floyd Bresee suggests that on any given Sabbath "as many as $80 \%$ of Adventist sermons preached are preached by lay preachers."

The responsibility of preaching the Word of God is to be carried out by lay persons (in addition to clergy), but they have limited experience, little or no training to properly feed hungry and waiting congregations with the preached Word of God. Is there a model, a class, a training manual, or a process that pastors can use to equip lay persons to preach?

${ }^{3}$ Matthew 28:19-20 (NIV).

${ }^{4}$ Telephone interviews and conversations with Illinois Conference pastors overseeing two to four church districts during the years of 2006-2008.

${ }^{5}$ Bresee, Successful Lay Preaching, 13. 
Even for the best preachers know how difficult it is to preach to today's audiences, be they a church worship services or public evangelism. It's a steep up-hill challenge to preach to contemporary and postmodern audiences, Christian or not. Our age of cutting-edge communication, high-tech media, HDTV, increases the challenge to preach effectively even for professionally trained preachers, how much more daunting are these challenges for lay preachers.

\section{Statement of Task}

In response to this need I have been involved in teaching church elders and lay preachers in my churches for the past four years. The obvious need in my ministry has inspired me to design and develop an effective, lay-friendly model to teach the average lay person to preach. This model focuses on biblical, historical, and practical methods that will awaken the gift of preaching and develop an army of lay preachers in the Chicago area. My ministry assignment was pastor for a multi-church district-both city and west suburbs of Chicago-keeps my purpose and perspective down-to-earth and real. This model is a wholesome plan that takes the student of preaching from start to finish at a reasonable pace that facilitates steady growth and maximum learning. Ministry opportunities afforded me to preach and teach around the United States, and overseas, have afforded me occasion to meet, converse and hear what those lay leaders-elders, youth speakers, deacons-are saying. I have heard their need, frustrations, wishes and dreams.

\section{Methodology}

A preaching course was designed, developed, and implemented to train lay 
persons to preach. The course was used twice yearly over a three-year-span for 4 and 12 weeks, each time involving a different group of students and class make-up. This project is a developed model designed to provide the church with a practical, adaptable, and effective course that trains and mentors lay persons to carry out their God-given commission to preach the gospel. This project seeks to stir and motivate lay persons to discover their gift of preaching. It will combine foundational principles along with practical steps from the ministry of Jesus to teach and train lay persons to preach. A case study approach will be followed to study a ministerial practice (and the lack thereof) in training lay persons to preach.

The course involved teacher presentations, class lab sessions, student presentations, hands-on sermon preparation time and preaching. Students had to develop and preach two class sermons, evaluate others, work in teams, take quizzes, a comprehensive final exam, and graduation ceremony.

Evaluation instruments used throughout the course included: sermon critique form, class evaluation form, instructor evaluation form, member survey to measure preaching growth of the class participant, a survey to measure effectiveness of mentoring aspect of the course.

\section{Justification}

The reason for this project is built on the mission and ministry Jesus left His church and disciples. Since Jesus utilized preaching greatly in His ministry, trained, and modeled preaching to His disciples, it is imperative for leaders of His church today to seek effective ways to teach and train today's disciples in the ministry of preaching. Jesus' disciples gave high priority to preaching, for immediately after they were filled the 
Holy Spirit on the day of Pentecost, they began to preach. The purpose of this project is two-fold: it clarifies and supports the foundational belief that there is a "priesthood of believers," ${ }^{, 6}$ and the gifts of the spirit are the complete ministry of the church of Christ. Thus, professional and lay leaders complete and support each other to make a well rounded ministry. Also, it offers a specific model of interactive training for lay persons to learn solid preaching skills based on biblical principles. This is the carrying-out of the scriptural mandate to "make disciples," "edify, and build up the body of Christ.", Howard Grimes gives perspective to this problem when he states, "The the Laos is God's pool of ordinary servant-people whom He chooses, anoints and appoints, but have been snatched away and needs to be re-enlisted in the preaching ministry"9 The American Church may now face a larger problem, that which he terms this problem as the "re-enlisting" 10 today's laity in the preaching ministry. The clergy are running a monopoly on many of the public ministries of the church-especially that of the preaching ministry. In their book God's Frozen People, Mark Gibbs and T. Ralph Morton propose the following diagnosis: "Without deliberate planning ... the congregation has developed a structure that depends entirely on the ministry... This is seen as so natural that most people will say that it is only right; that this is why you have ministers at all; that this is their joy; this they are trained. But for all that, this is what is crippling the life of

\footnotetext{
${ }^{6}$ I Peter 2:9 (NIV).

${ }^{7}$ Matthew 28:19 (NIV).

${ }^{8}$ Ephesians 4:16(KJV).

${ }^{9}$ Howard Grimes, The Rebirth of the Laity (New York: Abingdon, 1962), 14.

${ }^{10}$ Tbid., 14.
} 
church." Grimes tackles and diagnoses the problem. He advocates for a plan to halt the exodus of laity from proclamation and re-enlist them in the preaching ministry. He sees this trend as a significant departure from the heritage left by the founder of the Church of the first century." ${ }^{\prime 2}$ Jesus was a lay person who called lay persons; He trained and equipped them for ministry; that specifically of the preaching ministry.

The following is a list of eight justifications of this project:

1. God placed high value on preaching as a choice method to reach the lost and minister to believers (John 3:2; Matt 4:27; 12:41; I Cor 1:18, 21).

2. God wants His church to bear much fruit (John 15:16) and says "the harvest is white and laborers are few" (John 3:13; Matt 9:37; Rev 14:15).

3. God gave gifts to His church for the work of ministry (Eph 4), and commissioned believers (both clergy and laity) to "go therefore and make disciples" (Matt 28:12-20).

4. Preaching is God's method of building up the body, strengthening and growing their faith, and making disciples (Rom 10:14, 17).

5. God placed clergy to teach, train and equip the body to do the work of ministry, and Jesus called followers to be trained so He could send them to build up the Kingdom of God (Eph 4:12; Rom 10:15; 2 Tim 4:2; Mark 3:14). 1965), 49.

\footnotetext{
${ }^{11}$ Mark Gibbs and T. Ralph Morton, God's Frozen People (Philadelphia, PA: Westminister Press,
}

${ }^{12}$ Howard Grimes, The Rebirth of the Laity (New York: Abingdon, 1962), 12. 
6. Many pastors have multiple districts and lay persons are willing to preach, but acknowledge their need for training.

7. I am convinced that the local pastor is the first line of training for his members. He calling to teach and preach begins with providing consistent training to his lay persons. It is here that the local pastor is in need of a biblical model with a theological foundation and practical approach to teach lay persons to preach. ${ }^{13}$

8. God's church, in general, and pastors, in particular, are in need of a training model that is effective and practical for lay persons to preach. This model is to be one that does not emphasize scholastic and professional language. An effective model for training lay persons in preaching needs terms and language, approach and method that will give today's lay person a down-to-earth, hands-on, integrative-experience in the full scope of preaching.

\section{A Case Study as an Illustration of the Problem}

It was Friday evening, the July summer heat was intense, but the intensity, the heat and frustration all came together when I got the call: "Hello, Pastor Coleman? This is ... I am so sorry to have to cancel our speaking appointment for tomorrow. I cannot make it to preach to your Goshen congregation. I have a family emergency and have to go to Texas, my father is very ill. I cannot be with you this Sabbath." The weekend was filled with a variety of witnessing activities, special church services, and I had committed

\footnotetext{
${ }^{13}$ There is a notable absence of Seventh-day Adventist training material and literature on lay preaching. Specifically, there are only a few small handbooks written by church leaders or pastors that are in print. More troubling is the absence of local pastors using any materials or doing any training of lay. persons to preach with a comprehensive approach.
} 
to preach at another local church. It is the last minute, and my two capable speakers are away, and other Goshen lay persons are not able to preach with such short notice. This ministry problem I had faced before, but this was the "tipping point." The problem now was a giant, it looked like a monster. What is a pastor to do with such a problem during this critical time in Earth's history?

I thought of some wonderful lay leaders who loved to witness and to give Bible studies, they knew how to lead youth programs and help with community needs, but for this problem they only had questions: "Pastor what would I say? I don't know where to start and I have never preached before, so what would I do?" That was my question: "What would I do?"

There were other situations where the issue was a little different, but the problem was the same. Lay persons, church elders, departmental leaders and ministry-team leaders were assigned to speak for an afternoon service, or a special Friday evening vespers and Sabbath worship service. They would ask, "Pastor, can you give us some help in preparing the message for personal ministries day?" "Pastor, I am stuck, I don't know what to preach, or where to begin. I have done this before, but it takes more time and study than I anticipated. Can I and our other elders and lay persons get some training so we can ably feed God's people?"

\section{The Theoretical and Theological Positions}

The theory behind this project is based on lay persons being trained to preach for ministry. The theory is based on three theological assumptions: First, ministry is the calling of both the clergy and the laity. Second, the Holy Spirit gave gifts to the church and the members of the church for work of ministry. Third, pastors are called and trained 
to train and equip the body of Christ and its members, on how to use and develop their gifts.

These three assumptions are supported by four key areas: ${ }^{14}$

1. The strength of Scripture. ${ }^{15}$ The Word of God charges the prophet, priest and king to "build up the body of Christ," 16 calling us to "go make disciples" 17 for the work of ministry.

2. The strength of reason. Godly wisdom, directing the church over the centuries to do what makes good sense. Like any team, sports and non-sports teams, who have back-ups for all their positions. They are always developing and training a younger group to learn and eventually partner, then step-up to that position. Ministry can follow good reason also.

3. The foundational support of tradition. The church's tradition of training lay persons in many areas of ministry: church administration, witnessing, evangelism, community service, worship, leadership, etc.

4. The strength of experience. Years of ministry experience, of ministry soldiers who have taught us all that experience is a great teacher and foundation to all we do; my colleagues have struggled, learning from what does not work and what the situation and

${ }^{14}$ William R. Yount, Called to Teach: An Introduction to the Ministry of Teaching (Nashville, TN: Broadman \& Holman Publishers, 1999), 26.

${ }^{15}$ Ibid.

${ }^{16}$ Ephesians 4:16 (NIV).

${ }^{17}$ Matt 28:19. 
conditions call for. ${ }^{18}$ My personal experience as pastor has pointed to the need, highlighted and illustrated by weekly and yearly needs of the local church to share the pulpit and have a balanced group of preachers declaring God's Word.

Therefore, both theory and theology give foundation and support to the importance partner and interplay to give solid support to the need and thus an intentional and effective plan to be activated, evaluated, and demonstrated as we grow ministry among both clergy and laity.

\section{Limitations}

Research methods included observation, evaluation, and narrative descriptions of the researcher that chart the journey of this ministry project and its process. This project was limited to Seventh-day Adventist Churches in the Chicago metropolitan area, and individuals who desired to learn and commit their time to this class. The evaluation methods selected will give data relevant to this focus. This ministry project will mainly focus on the "pro-active" research method and apply a limited amount of "ethnographic" research methods. ${ }^{19}$ The ministry practice of developing a model to train lay persons to preach needs to intentionally engage in qualitative research that moves towards growth and transformation of the participants into better preachers than they were before the class. Since this project will give focus to the model or practice being evaluated, narrative descriptions (case studies) of both researcher (pastor) and the participants are

\footnotetext{
${ }^{18}$ Francis Cline and Dennis Turner, Research Methods for Ministry Projects (Grand Rapids, MI: Evangelical Press, 1976), 12-14.

${ }^{19}$ William R. Yount, Research Design and Statistical Analysis for Christian Ministry (Fort Worth, TX: W. R. Yount, 2006), 2.
} 
pro-active participants in this study. Both parties are jointly aware and involved for the best outcome of being better preachers and better trainer of preachers.

Pro-active education, in which there is open and risky learning on both teacher and student, gives much weight to observation, interviewing, journaling, and good use of documents. This should be enjoyable and rewarding, since many of these skills are at the core of good shepherding. Results will be presented in narrative description. The surveys, evaluation forms, questionnaires, group evaluations, and personal project journals are jointly participated in by pastor and lay persons.

The context of ministry is small to medium-sized congregations of Seventh-day Adventist. These churches are in a metropolitan area, both city and suburb, of Chicago. I was pastor of Goshen and Bolingbrook Adventist churches. Goshen is an inner-city church of Chicago and Bolingbrook is a suburban. I am not able to be at each church each Saturday for worship service. I usually alternate weeks between the two churches, and at times it may be a few weeks before I am in the pulpit or present at either, because of schedule or speaking engagements, or conference schedule, etc. So, I may have scheduled a guest speaker from another church, a conference officer, a seminary student, or other pastor to speak, but for the most part, it is the local lay person: an elder with some experience in preaching. They do the best they can, based on their experience, preparation or lack thereof. The Goshen church, in the city of Chicago, may have four to five lay persons I can ask (at least a month in advance and more) to speak.

Similarly, with the Bolingbrook congregation, when properly scheduled and with ideal timing and conditions, these lay preachers do ok. The expectation of the congregations for Sabbath worship is very high. Members live busy, crowded lives. 
Time is a tug-a-war of family time, work, school, church activities. Twenty to thirty percent of the congregation comes to mid-week services, ${ }^{20}$ so by the next Saturday (Sabbath) members are very hungry for a message that will give them clear Bible answers to their crowded lives. They expect to hear from one who knows the word and can communicate it will skill and expertise. One who can hold their attention, inspire, teach, motivate, and touch their heart. They do not mind hearing from a lay person, occasionally, but they want the Word of God preached with power to persuade and help them live the Christian life. Congregations are seeking persons who are trained to capably and confidently minister God's Word. This is the dilemma. Pastors know it and feel guilty when they have to be absent from the pulpit, and have to ask persons who have little or no training. Lay persons know it and feel guilty because they want to help, but know their limitations.

\section{Delimitations}

This course was designed to train and develop lay persons of Chicago area churches. As such, the target participant/audience for the seminar was the lay person of Seventh-day Adventist congregations in the metropolitan Chicago area. The approach of this course may not apply to lay persons of all cultures and regions. It may also not be applicable to all types of preaching. Yet, the process and outline of this project may yield an example to guide and prepare other lay persons within and outside of the United States of America, nationally and internationally, to preach; and model for other clergy how to train their lay persons in preaching.

\footnotetext{
${ }^{20}$ Based on attendance records of my district (Bolingbrook and Goshen churches) -12 months of the
} 
The scope of the project is as such: it provided training to lay persons who heard of the training and registered in specified time; class size of a maximum of twenty-five persons; lay persons needed recommendation from a church; the course duration was twelve weeks; students listened, interacted, and performed, sat for a final exam and participated in a graduation ceremony. The course was limited to two hours each Saturday afternoon for ten instructional weeks, with two additional weeks-one Friday and Saturday weekend for students to preach sermons, and a final Saturday afternoon for graduation ceremony. Lastly, the course was offered two times yearly for three yearsPart I, in the Spring; Part II, in the Fall (Part I was a prerequisite for Part II).

The project did not have representation of lay persons from every church, ethnic, cultural, or race. Factors such as interest level of motivation, literary ability, speaking experience, time to pursue the course, access to course location, finding and reaching persons interested in the training, may impact effectiveness of future lay training courses.

\section{Expectations}

This project will aim to successfully develop a model for training and mentoring lay persons to preach using sound homiletic and communication principles. This project will provide spiritual and foundational training, giving guidance in the preaching principles that are both simple and practical. It will help congregations and members to experience clear biblical exposition, effective application and illustrations and spirit-filled delivery from the preaching of their lay persons. This project will also produce a model program of materials to guide pastors and church leaders to initiate training for lay

year 2006 and 2007, 12 months. 
persons. This model will offer structure and support to the field as lay persons are trained to preach.

The project goals are outlined as such: (1) it will help me as pastor to equip and develop lay preachers in my, district churches, and other metropolitan Chicago area churches, (2)'this project will give pastors and church leaders in conferences, unions, and divisions, a model to train and coach lay persons in preaching, (3) this project will provide methods for pastors and leaders to use in training their lay persons to preach, (4) this project will strengthen and increase the pool of lay preachers, so that more reapers will be available to reap the ready harvest, (5) this project can be approved by NADEI(North American Division Evangelism Institute) as a continuing education class (for credit), (6) this project will increase my knowledge, awareness, and effectiveness as a teaching ambassador for the preaching of the everlasting Gospel, (7) this project will be accepted for publication as a model-manual for training lay persons to preach. These expectations will contribute to the growth of lay preaching. Lay persons will be empowered to partner with pastors in the preaching ministry to facilitate personal and collective spiritual growth of the individual believers and the salvation of souls.

The instructors and students of lay preaching will develop a fellowship and camaraderie of love and respect for the preached Word God. They will develop a growing hunger for God's Word, resulting in becoming better preachers, devoted disciples of Christ. Both will be challenged to become better listeners, students, preachers, and soul winners.

Instructor and student should experience increased motivation to participation in other programs and activities that draw clergy and laity together as a well-rounded team. 
Haddon Robinson, observes that preaching textbooks do not directly teach and train preachers on how to motivate audiences to action in the preaching context. ${ }^{21}$

As the project is activated, duplicated, and multiplied in churches and around the field, it should bring renewed excitement, motivation and participation to complete the work of ministry. This model can be a catalyst for an "army of workers, rightly trained," 22 Spirit-filled, to position God's church for a revitalized ministry through the witness of the preached Word by both clergy and lay persons.

The thesis implementation of this biblically developed model to train lay persons to preach will increase the number of prepared lay preachers and revitalize interest of other lay persons for preaching in the Chicago area churches.

\section{Definition of Major Terms}

The following terms are defined to for the purposes of this study; the reader should understand these terms in the following contexts:

Clergy: canonical use of this term is distinct from modern use in that it emphasizes God's call on lay persons with His anointing them to a prophetic/priestly role through schools of the prophets, rabbinical and. The modern use of the term refers to the body of professionals, distinct from the laity by their formal training, ordination, and/or

\footnotetext{
${ }^{21}$ Haddon W. Robinson, Biblical Preaching: The Development and Delivery of Expository Messages (Grand Rapids, MI: Baker Book House, 1980), 26-30. The issue and concern of the state of preaching, is that there is lack of motivation of both clergy and laity. If clergy are not motivates, how does this impact the training and potential for laity to be motivated for interest, training and growth in the preaching ministry.

${ }^{22}$ Ellen G. White, Instruction for Effective Christian Service (Washington, DC: Home Missionary Dept. of the General Conference of Seventh-day Adventists, 1947), 72; Ephesians 6:4 (NIV).
} 
licensed for the ministry of the Word and the work of the ministry. They are paid by the church for their service of ministry to the local church and larger organization.

Lay persons/Laity: canonical use of this term is distinct from modern in that all who were not of the prophetic/priestly order were laity. The modern use refers to all members of the Body of Christ whom the Holy Spirit gave gifts for the work of the ministry; the non-paid volunteers who are not hired by the organized church, but give of their time, talent, and resources to the work of God through the local church.

Local Church: congregations of believers who meet for worship, fellowship, service, and ministry. Each local church is a part of the larger "Body of Christ" and are called the "people of God" throughout the New Testament. ${ }^{23}$

Lay preacher: the person/s gifted and called by the Spirit of God, who proclaims the Gospel of Christ in assemblies of worship, evangelism, and at outreach occasions to the public. These persons may or may not be ordained to a office, to embrace this designation and are non-paid volunteers.

Lay training: the teaching of biblical and practical methods to lay persons by those who have been trained and are experienced in the rudiments of ministry: specifically for this project, that of preaching.

Preaching: the term for the ministry of specific oral proclaiming the Word of God without limitation to place, culture or people, by the power and authority of the Holy Spirit. The act of declaring God's word and deeds, and applying them to life; shedding light on life by reading, teaching, exposing, and expounding God's Word to the listener.

\footnotetext{
${ }^{23}$ I Peter 2:10; I Corinthians 2:27.
} 
Speaker: the term and designation equivalent to "preacher/lay preacher," it however can be a preferred designation for the Christian communicator among nonChristian and secular audiences.

Sermon: the oral, spoken Christian means of communication. In this study it is equal with talk, lecture, and presentation. It possesses the elements of purpose, form, style, function, and authority, delivered in a specific place and time by inspiration of the Holy Spirit.

Congregation/audience: the body of listeners gathered to as recipients of the sermon/speech delivered orally. Any group to which the Word of God, the Gospel of Christ is being delivered.

Application: connection of the message of God's Word, Scripture, in an impactful way to the lives of the listeners and audience.

Text: the portion of Scripture chosen as the foundation and focus of the sermon.

Exegesis: the study of the words, phrases, and grammatical make up of the text that gives the holistic meaning.

Coaching: the on-going process of teaching, training, and mentoring of persons for a specific purpose and discipline of preaching. For the purposes of this study coaching is one-one mentoring that continues the process of teaching and training preaching.

\section{Area of Study}

Work previously done in this area of study is rare; research done has been scarce. Yet at fare amount of writing can be found pertaining to the broader area of lay ministry. Dissertations: A Biblically Based Instruction Program in Preaching for Local Church 
Elders and Lay Persons to Preach in the Philippines, by Archibald A. Tupas; Holistic Approach to Preaching: A Training Program for Lay Speakers of Manhattan SeventhDay Adventist Church, by Victor V. Dyman; Preaching By Discovery: A Training Program to Help Lay Speakers Develop Style of Preaching that Motivates to Action, by Michael A. Mnich; A Training Seminar for Preaching: Developing Effective Preaching Skills, by Frank Ottati; books: God's Frozen People, by Mark Gibbs and T. Ralph Morton; A New Frontier: Every Believer a Minister, by Rex Edwards; Lay Ministry: Empowering The People of God, by Gilbert R. Martin; The Lay Preacher and His Work, by The General Conference of Seventh-day Adventists; Successful Lay Preaching, by Floyd Bresee-will be reviewed. These sources tackle the specific issue of the training, or lack thereof, for lay persons in the ministry of preaching. These sources provided research data, approach, insight and projects that served this program to teach lay preaching. They have left significant contribution to bridging the gap of training laypersons in preaching by addressing the biblical mandate, the model of Christ and the need of our time to equip lay persons for this area of ministry: lay preaching.

\section{Overview of the Dissertation}

For centuries lay persons have been made to feel second-class, inferior, an unwelcomed partner, and a step-child to preaching. Time, attitudes and actions have made a cumulative effect of unspoken and spoken inferiority among lay persons when it comes to preaching. History and pattern have told the lay person that clergy ask them to preach mainly when they (clergy) cannot be there; not for their love, knowledge and 
commitment to preaching The Word of God. They cannot be compared to the professional pastor and clergy leaders.

Thus chapter 2, Foundations for Training Lay Persons to Preach, goes right to the foundation of God's call for witnesses to His Word from all his people, and answers the question of whether lay preaching is biblically legitimate and theologically sound. It explores OT foundations, patterns and examples in training "God's mouthpiece." A survey of the NT foundations, patterns and example of how Jesus left a model for training of lay preachers follows; how His disciples propagated this model. Chapter 3, A Literary Review of Lay Preaching, gives foundations from Christian literature-a historical journey of the steady growth and quick decline of lay preaching; it explores the foundational principles and teachings for lay partnership with clergy for a "finished work" in the writings of Ellen G. White, ${ }^{24}$ foundations in current literature-it's theology, psychology and pragmatics. Chapter 4, A Model for Training Lay Persons to Preach, describes a holistic-ministry model with a balanced approach that fits the field, which includes design and implementation of the project; course organization and development; proposes a coaching-component of the project-a path and plan for ongoing training of lay preachers. Chapter 5, Evaluation of the Project: individual, focus groups, church members, lesson plans, project format, and teacher/facilitators. Finally, chapter 6 is the Summary, Conclusions and Recommendations. It contains the summation of this dissertation. It reviews the model project for training lay persons to preach, preaching

\footnotetext{
${ }^{24}$ Ellen G. White is a founding member of the Seventh-day Adventist Church and her writings are highly honored, valued and referenced since she is considered a prophet to the church for the "last days."
} 
courses, coaching model, and outlines recommendations for future research and ministry training for lay persons. 


\section{CHAPTER TWO}

\section{FOUNDATIONS FOR TRAINING LAY PERSONS TO PREACH}

\section{Introduction}

This chapter will survey the foundational basis of preaching. We will explore how the Bible, OT, NT, and the writings of Ellen G. White, have given the biblical and theological basis for training lay persons to co-labor with God in the salvation process by proclaiming the Word of God. Our first survey explores the OT principle and practice, set in motion by God-the account of God's interaction with man. Our second survey mines the rich soil of the NT and traces the account of New Testament examples of the training and deployment of lay persons as God's chosen and empowered means to preach the Good News.

\section{OT Biblical Foundations for Training Lay Preachers}

From creation, God chose to teach, train and engage His children in the work of His Kingdom. He taught and trained Adam and Eve, the prophets, priests, and peoples His ways and methods of proclaiming His love and demonstrating His ways to all mankind. God defined man's purpose as divinely declared in Gen 1:28 when He said, "Be fruitful and multiply; fill the earth and subdue it; have dominion." This section will consider OT examples and note how God established the purpose, process, and people for the proclaiming His Word thus initiating and propagating Christian ministry. 
God created Adam and Eve and the generations of bible leaders: Enoch, Methuselah, Noah, Abraham, Jacob, Joseph, Moses and Aaron etc., to pass on His Word by mouth. These were the first lay persons speaking to their children and grand-children, and generations, the statues, precepts and commandments of God. This is the foundational assignment given to every parent and spokes-person/preacher.

A foundational principle of the God's Kingdom was given when God reiterated Heaven's proclamation plan through oral tradition. God speaking to His children through Moses says: "Only take heed to yourself, and diligently keep yourself, lest you forget the things your eyes have seen, and lest they depart from your heart all the days of your life. And teach them to your children and your grandchildren, especially concerning the day you stood before the LORD your God in Horeb, when the LORD said to me, 'Gather the people to Me, and I will let them hear My words, that they may learn to fear Me all the days they live on the earth, and that they may teach their children.'”(Deut. 4:9-10) ${ }^{1}$ Note the key phrases in this verse: "let them hear My words," "that they may learn," and "teach their children." These three important phrases are foundational to God's proclamation plan. God's plan was that each parent and person 'hear,' 'learn,' and 'teach.' This original plan involved and employed each created person to be a mouthpiece for God. So important was this concept that in Deuteronomy, at least eight verses (Deut $4: 9,10 ; 6: 6-9 ; 11: 19 ; 31: 19)$, were employed to highlight the importance of God's proclamation plan. Each created person was to "hear" ("take heed" KJV)-intently and

'Deuteronomy 4:9 (KJV). 
consistently stand before God to listen to "every word that proceeds from the mouth of God" (Matt 4:1-3); "learn"- understand and observe what God teaches; "teach"-to speak into the hearts and minds of "their children and grandchildren, that they may teach their children" (Deut 4:9, 10). Matthew Henry comments on this passage: "Care must be taken in general to preserve the entail of religion among them, and to transmit the knowledge and worship of God to posterity; ... Parents must, in order hereunto, particularly take care to teach their own children the fear of God, and to train them up in an observance of all his commandments[Word]." It is important for our study of the biblical foundations of lay preaching for us to consider and understand key Old Testament terms and words that pertain to this subject matter.

\section{OT Biblical Terminology for Lay Preaching}

Biblical words contribute to the foundational basis for lay preaching. Word studies can yield a wealth of meaning and hold the key to opening doors through which we can gain critical understanding of lay preaching in the scriptures. Selected Hebrew words of the Old Testament will be studied in their context as they relate to lay persons, clergy and preaching. These word studies will aid in our search for Biblical foundations to lay preaching and will prove to be the cornerstones of those foundations.

There are many biblical words used to capture the meaning of the Bible concepts of "prophesy" and "preach." Seventeen Hebrew words were considered: dabar, malal, mashal, 'amar, qara', za'aq, 'ashar, 'anah, nagad, chavah, shama', tanah, nada', na'am,

\footnotetext{
${ }^{2}$ Matthew Henry, "Matthew Henry's Complete Commentary on the Whole Bible," BibleStudyTools.com, http://www.biblestudytools.com/commentaries/matthew-henrycomplete/Deuteronomy/4.html?p=3 (accessed May 20, 2010).
} 
chazah, nataph and basar; referring to terms: "speak," "cry/cry out," "tell," "prophesy," and "preach." This study will focus on six main Hebrew words: dabar, 'amar, shama', naba', qara' and basar.

Dabar means to speak, declare, converse, communicate, promise and talk with one another. Here is it's frequency of usage for meaning in the KJV: (miscellaneous: 38 , command: 4 , utter: 7 , pronounce: 14 , commune: 20 , tell: 25 , promise: 31 , talk: 46 , say: 118 , speak: $840 .{ }^{3}$ The most basic meaning of Dabar is to speak, say, and talk. It is used over 1050 times in the OT; most predominantly in the Pentateuch. It appears early in scripture as God dialogued with Noah. "Then God said [dabar] to Noah, go forth from the ark (Gen 8:15 RSV)." God speaks, Noah listens; then Noah will announce what God told him to the waiting occupants, they listen and will carry out the instructions of God. It is used in Gen 12:14: "So Abraham departed, as the LORD had spoken [dabar] unto him." Lot "spake unto his sons in law" (Gen 19:14); "And God spake [dabar] unto Moses, saying, speak [dhavar] unto the children of Israel, saying" (Lev 1:1); Isaiah would "Speak [dhavar] comfort to Jerusalem" (Isa 40:2). Vine's Expository Dictionary says the biblical phrase is "the word of the Lord." This word depicts communication. Yet, God uses it as He communicates through the lay person he chooses to speak through, to reach His people. God uses dabar as He communicates with lay persons who are not clergy of those times. His plan was for them to respond by relaying His messages to the ones God specified.

\footnotetext{
${ }^{3}$ The KJV Old Testament Hebrew Lexicon, "Dabar," http://www.biblestudytools:com/lexicons/ hebrew/kjv/dabar.html (accessed March 2, 1999).
} 
'Amar means to say, to speak, to utter, to command, to promise and to answer. It is a staple word of the OT: used over 5181 in the NAS translation. Significant frequency of usage is found in Genesis and the prophets, and found in almost every book of the OT. 'Amar is the verb used repeatedly (over thirteen times) in the creation account ${ }^{4}$ as God speaks "Let there be light," "Let there be firmament," "saying, be fruitful and multiply (Gen 1:3,6,22 NAS). These are the powerful creative pronouncements that brought about all creation. However, it is also used of God's chosen spokes persons-prophets and preachers: "He (Pharoah) said ['amar] to his people, 'behold, the people of the sons of Israel are mightier than we"" (Ex 1:10). It appears often as God converses with and instructs his servants what to say: "Then you shall say ['amar] to Pharoah, 'thus saith ['amar] the LORD,' "Israel is my Son, my first born" (Exod 4:22 NAS). This is a common word used as God's communicated with his servants, people, and even enemies. "Come now, and let us reason together," Says the LORD, "Though your sins are as scarlet, They will be as white as snow; Though they are red like crimson, They will be like wool" (Isa 1:8). Then the response of the people as they speak [Amar] to their God: "And many people will come and say, "Come, let us go up to the mountain of the LORD, to the house of the God of Jacob; That He may teach us concerning His ways And that we may walk in His paths." ${ }^{.5}$ Another biblical term that was not limited to professional clergy, but used as God spoke to his lay messengers who were His prophets and preachers.

\footnotetext{
${ }^{4}$ James Strong, "A Concise Dictionary of the Words in the Hebrew Bible," in The Hebrew-Greek Key Study Bible, ed. Spiros Zodhiates (Chattanooga, TN: AMG Publishers, 1991), 1606, 1607.

${ }^{5}$ Isaiah 2:3 (NAS).
} 
Shama' has a dual-side meaning: first, it means to listen, to hear, to pay attention with interest and obey; second, it means to tell, to proclaim-sound aloud. ${ }^{6}$ It is a basic and frequently used Hebrew word for listening and telling. It is most frequently and commonly refers to all kinds of persons listening to God, his representatives, and. speaking to all people as God's spokes persons. It is used over 1159 times; with highest occurrences in Jeremiah, Isaiah, Deuteronomy and Psalms. ${ }^{7}$ God gets Israel's attention when He communicates warning of judgment through Jeremiah, His spokes person: "Hear [shama'] the word of the LORD, O house of Jacob, and all families of the house of Israel'(Jer 2:4). Over and over in this book God instructs his prophet to tell [shama'], proclaim, of need to repent for judgment is pending. The call of Isaiah (6:8-10 NAS) is an example of how God's chosen spokes person will listen, hear and tell:

Then I heard [shama'] the voice of the Lord, saying, 'Whom shall I send, and who will go for Us?' Then I said, 'Here am I. Send me!' He said, 'Go, and tell [shama'] this people: 'Keep on listening [shama'], but do not perceive; keep on looking, but do not understand.' Render the hearts of this people insensitive, their ears dull, and their eyes dim, otherwise they might see with their eyes, hear [shama'] with their ears, understand with their hearts, and return and be healed.'

At times God spoke to his people, saying "Now, O Israel, listen to the statues.... I am teaching you to perform.".8 Shama' is a term used of God, his spokespersons, and His people as a whole; not limited to priest or clergy.

Nada means to prophesy, and to prophesy under the influence of Divine Spirit. It

\footnotetext{
${ }^{6}$ The KJV Old Testament Hebrew Lexicon, "Shama'," http://www.biblestudytools.com/lexicons/ hebrew/kjv/shama.html (accessed March 2, 1999).

${ }^{7}$ Strong, "A Concise Dictionary of the Words in the Hebrew Bible," 1610.

${ }^{8}$ Deuteronomy 4:1 (NAS).
} 
occurs 102 times primarily in books of Ezekiel and Jeremiah. ${ }^{9}$ These accounts specify that the prophecy is of God: "Therefore prophesy [nada] against them, prophesy [nada], O Son of man;" "So I prophesied [nada] as He commanded me" (Ezek 37:10 NKJV).

Those prophesying were lay persons God chose and made prophets. Amos was a prime example of a common man who was not a priest or Levite, but one taken from "among the shepherds of Tekoah" (Amos 2:2 RSV). Scripture records that Saul prophesied, and he was a full-time prophet (I Sam 10:6); Miriam, sister of Moses and Aaron, was a prophetess (Exod 15:20). True prophets are not of one gender or blood line, but those who God selected and sent by the power of His Holy Spirit to speak His word.

Qara' means to call, call out, recite, read, cry out, proclaim, to utter a loud sound, call (with the name of the Lord), to read aloud, to summons, to invite, to be called, name, be named, to be called out, to be chosen. ${ }^{11}$ The KJV uses this term over 735 times; "called": 528, "cry": 98, "read": 38, "proclaim": 36, and "preach": 2; highest occurrence is in Genesis, Jeremiah, Isaiah and Psalms. ${ }^{12}$ 'Qara' is first used in Genesis-extensively so. It is found in Gen 1 when "God called [qara'] the light day, and called [qara'] the darkness night" (verse 5); "God called [qara'] the firmament heaven" (verse 8); "God called [qara'] the dry land earth" (verse 10). Similarly, this term describes Adam's task of naming the living things: birds, beasts, cattle: "And out of the ground the LORD God

\footnotetext{
9Strong, "A Concise Dictionary of the Words in the Hebrew Bible," 1604.

${ }^{10}$ Ezekiel 6:2 (NAS).

${ }^{11}$ The KJV Old Testament Hebrew Lexicon, "Qara'," http://www.biblestudytools.com/lexicons/ hebrew/kjv/qara.html (accessed March 2, 1999).
} 
formed every beast of the field, and every fowl of the air; and brought them unto Adam to see what he would call [qara'] them: and whatsoever Adam called [qara'] every living creature, that was the name thereof' (Gen 2:19). Then Adam, speechless after seeing his helper, declared "This is now bone of my bone, flesh of my flesh: she shall be called [qara'] woman, because she was taken out of man" (Gen 2:23). The fourth chapter of Genesis records a transformative time, the birth of Enosh, the son of Seth. It states that the people "began to call [qara'] upon the name of the Lord" (4:26). This verse begins a pattern of scriptural revival among God's people characterized by "qara," a coming back to God, a renewed reliance, dependence and acknowledgement of His sovereignty. It represents the humility of people returning to God. The Psalms uses this as the "cried out [qara $]^{\prime \prime 13}$-prayer of urgent need, humble returning, over 72 times. Isaiah continues the revival theme as he invites all to "Seek ye the Lord while He may be found, call [qara'] ye upon Him while He is near" (Isa 55:5). A classic occurrence, and perhaps the most remembered use, is the OT prophecy describing the ministry and preaching of Jesus: "The Spirit of the Lord is upon Me, because He has appointed Me to preach [qara'] the good tidings to the poor" (Isa 62:1 RSV). This is followed by the great prophetic promise-invitation "And it shall.come to pass that whosoever calls [qara'] on the name of the Lord shall be saved." The many uses of range from the father of the human race, Adam, the Psalmist, the prophets, the common people, and Jesus the master lay preacher.

\footnotetext{
${ }^{12}$ Ibid.

${ }^{13}$ The Psalms is filled with prayers. Qara' is a prayer that runs throughout the Psalms. Some examples of these "prayer calls" are: Psalm 3:4, 4:3, 17:6, 18:6, 22:2, 27:7, 30:8, 34:6, 66:7.
} 
Basar means to receive good news, proclaim news, publish, to show forth, to gladden with good news, to announce (salvation) as good news. It occurs 24 times in the NAS. ${ }^{14}$ In 2 Sam 1, 4, and 18 it is used of military watchmen, soldiers, bearing good or bad news: "Behold another man running by himself. This one also is bringing [good news [basar]"" (2 Sam 18:26 NAS). This word is also used when David mourns Saul's and Jonathan's death: "Tell it not in Gath, proclaim [basar] it not in the streets." 15 The actions of this word, in their contexts, describe that which can be performed by all people; not by a select group of professional priest or clergy, but by different individuals being the bearing, announcing, and proclaiming agent.

Select OT terms for preaching, "dabar" (to speak), “"amar"(to utter), "shama"” (to hear, to proclaim), "naba" (to prophesy), "qara"'(to call, name, call upon), and "basar" (to preach, bear news, publish), has given a wide range of OT words that were not limited to priest or clergy, laymen or professional leaders. Rather, they all depict God's predominant call and use of lay persons in the OT and future plans (as prophesied in Joel 2) use "all flesh." The main Hebrew words reviewed demonstrates that God in the biblical record did not limit the idea of speaking for God to professionally trained priest or clergy, but His spokes persons were and will be "a kingdom of priests."16

The OT basis for lay preaching is built on how God planned to proclaim Himself from parent to child, from generation to generation. The essential element of preaching (proclaiming God's truth) is each person-man and woman-created by God to pass on to

\footnotetext{
${ }^{14}$ Strong, "A Concise Dictionary of the Words in the Hebrew Bible," 1604.

${ }^{15} 2$ Samuel 1:20 (NKJV).

${ }^{16}$ Exodus 19:6.
} 
others by proclaiming God to all. Church historian, John Telford states: "And the Lay function has received its authentication by clear inference from the fact that under the ancient theocracy and throughout the whole period of the Hebrew monarchy the most noted of the holy men of old by whom God spoke to Israel were called from those who did not belong to the priestly order." ${ }^{\prime 17}$ The army of the earliest lay preachers is imposing: Moses, Job, David, Solomon, Daniel, Nehemiah and most of all the great prophets. ${ }^{18}$ The biblical record and sacred history account for the natural growth of God's army of lay preachers. Several prophets do not have their writings recorded in scripture, but were nonetheless spokes persons for God: Enoch, Noah, Joseph, Elijah, Elisha, Jehu, Eleazer, Balaam, Gad, Ahijah, Nathan, Huldah, Deborah - are some. There is a pattern in OT revival of godliness in Israel and Judah: they were fueled by the recovery, reading, teaching and living the Torah. The pattern of preaching the Torah in Israel was rooted in God speaking to the prophet, His direct command that His prophet speak to the people on His behalf, and the relaying of sacred stories. As the Torah and sacred activity of God with His people, Ronald E. Osborn states they were passed on in "a decidedly homiletical character." 19 OT lay persons have blazed the trails and paved the roads for laymen to take their rightful place and assignment to preach the Word of God. 1897), 2.

${ }^{17}$ John Telford, A History of Lay Preaching in the Christian Church (London: Charles H. Kelly,

${ }^{18}$ Isaac Taylor, Ultimate Civilization, and Other Essays (London: Bell and Daldy, 1860), 7.

${ }^{19}$ Ronald E. Osborn, Folly of God: The Rise of Christian Preaching, vol. 1 of A History of Christian Preaching (St. Louis, MO: Chalice Press, 1999), 84. 
The concept and calling of "messenger" and "witness" originated in the OT and was not just limited to the NT believers or church. This is the theme of witnessing-what you saw God do, what you heard God say. In the account of Israel's exodus from Egypt, God called for each and every Israelite, not only their priests or leaders, to be mouthpieces of what they witnessed and experienced; passing on the stories of their lives and experiences of their hearts to everyone. They were to speak the words: "The Lord brought us out of Egypt with a mighty hand and outstretched arm."20 Yahweh continually reminded Israel to pass on the story of God's activity among them when $\mathrm{He}$ said: "Only take heed to yourself . . . lest you forget the things your eyes have seen ... teach them to your children and your grandchildren" (Deut 4:9). The "us" (25:5-9) and "you" and "your" (4:9) refers to all who experienced deliverance from Egyptian slavery: men, women, young, old, leaders, followers-everyone. This all-inclusiveness in the call to share Word of God is the same humanity-wide promise given by God through Joel the prophet-"I will pour out my spirit on all people." 21

The messenger/witness motif of the OT is the same concept connected to the calling and lay ministry of Old Testament prophets. Bible scholars, Stanfield, Sangster, and Roddy, state that "These early preachers were 'laymen,' who felt impelled to deliver a message from their God." ${ }^{, 22}$ The similarity of the calling of the common person to be God's "mouth-piece," and the calling of each disciple to be a "witness is striking. God created all His children to pass on His Word-to be "His messengers," declaring His

\footnotetext{
${ }^{20}$ Deut 26:5-9 (NRSV).

${ }^{21}$ Joel 2:28, 29.
} 
message. John Telford in his classic, A History of Lay Preaching, records the role and historic impact of lay preaching in the throughout the OT. He summarized the foundation of lay preaching:

${ }^{22}$ Vernon L. Stanfield, Paul E. Sangster, and Clarence S. Roddy, Homiletics (Grand Rapids, MI: Baker Book House, 1974), 7. 
"And the lay function has received its authentication by clear inference from the fact that under the ancient theocracy and throughout the whole period of Hebrew monarchy the most noted of the holy men of old by whom God spoke to Israel are called from those who did not belong to the priestly order." Isaac Taylor confirms and captures this OT trend of lay preachers in his essay on "Lay Theologians." His list of lay preachers in the OT is impressive: Moses, Job, David, Solomon, Daniel, Nehemiah, Isaiah, Jeremiah, Hosea and most of the great prophets. Significant evidence for lay preaching during the OT times leaves little to dispute God's purpose, plan, and call of the laity to the preaching ministry. Taylor further claims that as laymen preached they were discharging a function of sacred calling, whether or not he might be of priestly parentage. The concept of the "priesthood of all believers" is God-established and designed. He spoke of this plan directly when He declared "and you shall be to Me the kingdom of priests and a holy nation" 23 -His plan was for each and every individual be a lay priest and lay preacher. $\mathrm{He}$ believes this tradition of the laity's involvement in preaching and other areas of religious service, gives support to historic and current trend "that they bear a large proportion to the entire number of Christian authors; and some who stand upon the list of names of the very brightest luster." Taylor poses a significant philosophical and ministry conclusion: "How absurd to permit laymen to write on the subject of religion, but forbid to preach on it. $" 24$

Lay preachers have been known to bring a stirring effect to ministry, from their

\footnotetext{
${ }^{23}$ Exodus 19:3-6 (RSV).

${ }^{24}$ Isaac Taylor, Ultimate Civilization, and Other Essays, 235.
} 
contribution to prophecy to their preaching and evangelistic effectiveness. Taylor was biblically accurate in his grasps of the patriarchal pattern of God calling and empowering lay preachers. J. Telford cites three of the many Old Testament examples of lay preachers called and installed by God to be prophets. "St Jude's words almost entitle us to describe Enoch as the first lay preacher.... Enoch's name is still surrounded by a halo of sanctity and of mystery." ${ }^{25}$ He goes on to name Noah as a "preacher of righteousness" and "supremely impressive by his daily work,"26 Abraham, a faithful man who ordered his own "great congregation"-" "his children and household after him"27 -and a useful lay preacher; "Moses was a layman," 28 the prince of Egypt who was trained in the ways of Egypt then called by God from the Shepherd's life of the desert to lead Hebrew slaves out of Egypt.

A review of the Pentateuch, the "Five Books of Moses,"-known also as the Torah or Law-reveals an imposing list of lay preachers. The preaching during these early times of biblical history was overwhelmingly lay preaching-non professional preachers. Lay preachers such as Enoch, Noah, Jacob, Aaron, and Balaam blazed a path for lay preaching. God's word to Moses, "Thus you shall say ... and tell the people"29 was substantially the same to these other lay preachers.

The life and ministry of Moses serve as a model of God's chosen method of

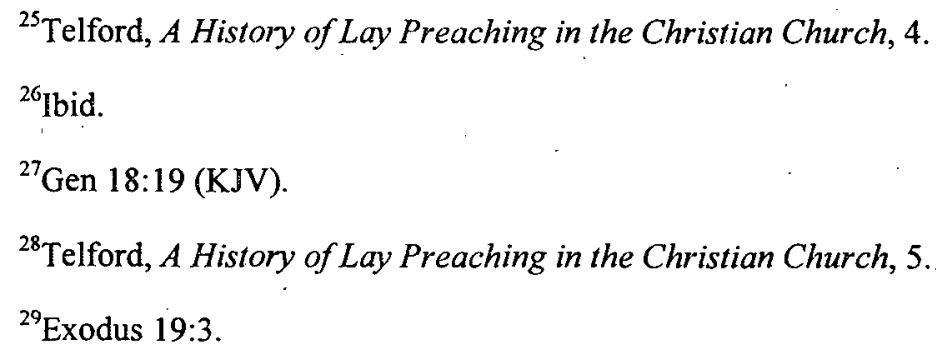


selecting and effectively using lay persons to minister, train and develop others to be lay witnesses and preachers. Telford refers to God instructing Moses to select and train seventy elders to be filled with the Spirit God had filled him with; they "should share with him the toils of administration. ${ }^{30}$ When the chosen men assembled round the tent of meeting the Spirit rested upon them, so that "they prophesied, and did not cease."31 This was such a change for others to adjust to, that the Joshua's reaction was for Elad and Medad to be silenced. He asked Moses to "forbid them,"32 but Moses' grasp of God's plan led him to reply, "would God that all the Lord's people were prophets, and that the Lord would put His Spirit upon them!"33 The significance of this instance and Moses' ministry is that God worked in his life to demonstrate and develop the Divine plan of the laity's appointed place in proclaiming God's word; they are to be his witnesses in great numbers. Moses' words and actions, during the leadership ministry of Israel, give godly affirmation that the gifts of the Spirit are in no way to be limited by pedigree or personal privilege, but God-given authority is conferred on lay persons to speak His Word. Isaac Taylor succinctly states that God has, and still does, exercise His right to send "out His seraphim with the hallowed fire of His altar to touch and purify the lips of whom $\mathrm{He}$ pleases." 34

The life and ministry of Moses profoundly models the God-given steps for the

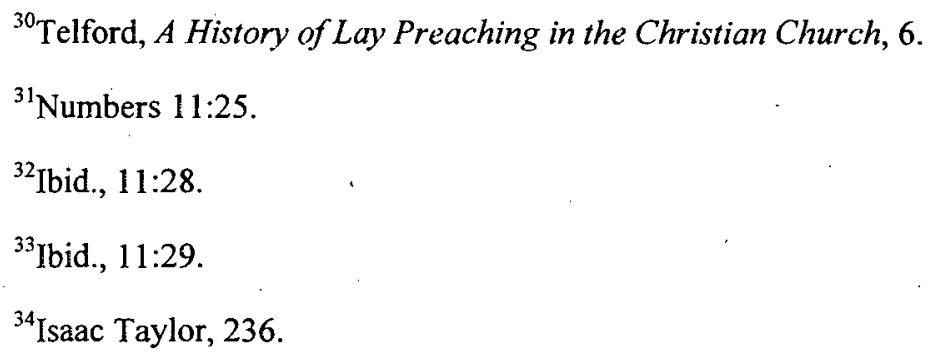


call and perpetual proclamation of God's Word. These Divine principles for proclamation can be stated as such: to listen, to learn, and to train. Moses listened to God, his life was one of constant communication with Heaven; he learned-followed and carried out God's specific instructions (and learned the hard lessons of not doing exactly what God said); he trained others, as God instructed, to take up the mantle and prophecy and preach the word of the Lord. ${ }^{35}$ The significance of this is profoundly summarized by Christian author, J. Telford, when He states: "The work is so vast, the need of witnesses is so great, that we are constrained to give thanks for every tongue that is unloosed to declare God's message. The ideal towards which the Christian Church moves is, that every member should be a witness and a messenger." ${ }^{36}$

Since Moses, the Jewish lawgiver, gave laymen God's Spirit and authority to be his witnesses and preachers, many other leaders of God's people have followed his example and taken up the mantle of listening, learning, and training lay persons to be preachers. The model and lessons are evident: leaders are not to judge, have prejudice, or limit the gifts of the Spirit of God, but we are to call laymen and confer God's Spirit upon them for the work of ministry. The preacher and hymnist, Charles Wesley, caught and captured this lesson in the prose of his hymn:

"Moses the minister of God

Rebukes our partial love,

Who envy at the gifts bestowed

On those we disapprove;

Shall we the Spirit's course restrain,

Or quench the heavenly firs?

Let God His messengers ordain,

\footnotetext{
${ }^{35}$ Telford, A History of Lay Preaching in the Christian Church, 7.

${ }^{36} \mathrm{Ibid}$.
} 
And whom He will inspire.

Blow as He list, the Spirit's choice

Of instruments we bless;

We will, if Christ be preached, rejoice,

And wish the word success. ${ }^{37}$

The patriarchal model of the Old Testament has given universal capacity for the prophetic office and the preaching ministry, with which we need to consider and embrace. It is God's welcoming of those called to preach and teach; He is still welcoming new recruits from among his people, to preach His Word. Samuel listened intently, learned specifically, and trained largely.

During the dark days of the Judges, when the priesthood became spiritually bankrupt, God called this young man and thoroughly prepared him. Samuel's ministry exemplifies the call, selection and training of laymen to the prophetic ministry-ministry of proclamation. He had set up a "college for lay preachers.",38 The scriptures account for women also, like Deborah, the prophetess, Isaiah and Jeremiah, and Elisha who show that prophets might receive a direct call from another prophet (Elijah).

The Bible also records that King Saul met a company of these laymen, trained in the prophetic office, so filled with the Spirit of God that it fell on him and he prophesied also. The Spirit-given gift of preaching is one that not only proclaims but is passed on, by those gifted of the Spirit, to others God plans to use to preach also. This is demonstrated in the Biblical account of 1 Sam chapter 19: While Saul was pursuing David, Samuel and David went to Naioth and there Saul's men "saw the company of

\footnotetext{
${ }^{37}$ Telford, A History of Lay Preaching in the Christian Church, 7. He quotes from Charles Wesley's Short Hymns on Select Passages of Scripture. Wesley wrote many hymns based on scripture passages that moved him. (Also see Enchiridion, Notes on Source books by C. Wesley).

${ }^{38}$ I Samuel 19:18.
} 
prophets prophesying, and Samuel standing as appointed over them." The same Spirit of God that led the company to prophesy fell on them and they too prophesied. Others were also drawn into the circle of Spirit-led prophesying (preaching). Then Saul also had the same spirit to fall on Him and he too prophesied. What a scene, what a telling picture. Samuel, the great prophet and prophet-maker, was so obedient to God's pattern that the prophets he trained passed on the gift from their anointing. Telford states, "all the company of prophets, moved by one divine finger, whose touch none of them can resist." ${ }^{39}$

The Old Testament scriptures witness to Jehovah sending His commands, counsels and revelations through the prophets. Of the prophets we can recognize God passing His spiritual revelations to Abraham (Gen 20:7), Moses (Deut 18:18), Samuel, David (Acts 2:30); all these were laymen who proclaimed God declarations. Many great witnesses never attended a school for prophets. God took Amos from Tekoah and led him directly to preach to the iniquity-filled cities of Samaria-an immediate baptism into the pools of preaching. Amos' words echo the path the many whose path to the prophetic preaching ministry as he declares, "I was no prophet, neither was I a prophet's son; but I was an herdsman, and a gatherer of sycamore fruit: And the Lord said unto me, Go, prophesy unto my people Israel" (Amos 7:14,15). His story is a blueprint of God's plan to use the least of these. Telford says, "His little prophecy, bearing the stamp of consecrated genius in every line, is an abiding vindication of God's choice of that lowly

\footnotetext{
${ }^{39}$ Telford, A History of Lay Preaching in the Christian Church, 9.
} 
'farm laborer' as His lay preacher to the princes and priests of 'the king's chapel' and 'the king's court."

The prophet, Joel, perhaps as none other, highlights and in glorious display God's design and delight in using the lay person in preaching. His "Magna Charta" prophecy, directly speaks of how God will use the laity in the final days of Earth's history: "And it shall come to pass afterward, that I will pour out my Spirit on all flesh; and your sons and your daughters shall prophesy, your old men shall dream dreams, your young men shall see visions: And also upon the servants and upon the handmaids in those days will I pour out my Spirit” (Joel 2:28,29). This prophecy is Divine decree that as God called and empowered those lay prophets of old, it is His promise to execute the same plan in crowning manner on the Christian Church. Perhaps no other prophecy so clearly and specifically delineates the all-encompassing scope of the preaching ministry of all believers. Note what is entailed and specified: "all flesh," "sons," "daughters"--will prophesy(preach); "old men," "young men," "servants," "handmaids"-Holy Spirit was promised to be poured out on all ages, genders and classes. ${ }^{41}$

The Old Testament's declaration and affirmation of the "priesthood of all believers" has been established in Joel 2. This call and promise to "all flesh" included women. Since priesthood refers to "faithful witness" for God, women played active roles because their status was that of laity. ${ }^{42}$ Here are examples of OT women who proclaimed the Word of God. Miriam was Moses' sister, who God chose and called along with her

\footnotetext{
${ }^{40}$ Telford, A History of Lay Preaching in the Christian Church, 11.

${ }^{41}$ Joel $2: 28,29$.

${ }^{42}$ Chapter 1 , "Definition of Terms" provides a starting definition.
} 
brother Aaron to serve Moses. ${ }^{43}$ Exod 15:20-21 speaks of her prophetic and leadership role in Israel: "Miriam, the prophetess, Aaron's sister." Judges 5:31 gives account of Deborah, the wife of Lappidoth, who judged Israel; and God gave authority to deliver messages. ${ }^{44}$ Huldah was a prophetess faithfully delivered God word of forgiveness to Israel. Her witness and proclamation led to significant reading of the word, repentance and change among God's people. ${ }^{45}$ Also, Isa 8 refers to Isaiah's wife as "the prophetess." These women, and others, were lay preachers of the OT.

In Summary, the Old Testament has given us God's foundational design and pattern for lay preaching; its purpose and plan have been demonstrated in the lives of lay persons called to be prophets (preachers). The seeds of the Spirit's outpouring were planted in the OT account forecasting an even larger harvest for New Testament timesthe Christian Church. As a father teaches and trains his children to carry on the family business, as one seed is planted and yields a hundred fold so the Spirit of God on OT laity will yield a rich harvest of lay preachers in the Christian Era. The Divine declaration, in Joel 2, opens the doors for "all flesh" to participate in preaching the gospel: young; old, make, female, bond and free, master and servant. Therefore, the seeds of lay preaching were planted in the OT by God's pattern, patriarchs, prophets and promise.

\section{NT Biblical Foundations for Training Lay Preachers}

The New Testament account will be examined to discover the foundational seeds

${ }^{43}$ Micah 6:4.

${ }^{44}$ Judges 4:6.

${ }^{45} 2$ Kings 22:13-18. 
of lay preaching in the ministry of Jesus, the Apostles, and NT disciples.

New Testament Christians opened the promised gift of the Spirit's outpouring "on all flesh." The baton of the Spirit of proclamation had been passed from the OT prophets to the NT believers. From the OT times the spirit of lay ministry was deep in the blood of believers, NT disciples were recipient of that history and heritage. The lay movement within Judaism created the culture, arena, and atmosphere for Christianity to flourish by lay participation, in general, and lay preaching, in specific. ${ }^{46}$ It is of this soil for lay ministry that J. Telford refers when he observes "There was no ordained or recognized ministry in the synagogues, which were completely under lay government. Readers of the Gospel cannot forget that to this peculiarity of Jewish life our Lord Himself owed many an opportunity of declaring His message. ${ }^{.47}$

An unexpected and unique observation is given in Professor Bruce's study of the synagogue ministry. His study uncovers "a deliberately planned, persistent, extensive effort to bring the ears of the men of Galilee, through the convenient medium of the synagogue, the good news of the kingdom of God. ${ }^{.48}$ In other words, the synagogue was the market place where the multitude gathered, and it was the pulpit from where spiritfilled believers preached the gospel. Jesus also was part of that tradition and climate. The Britannica Student Encyclopedia informs us that the synagogue was considered a

\footnotetext{
${ }^{46}$ George.H. Williams, "The Ancient Church, AD 30-313," in The Layman in Christian History: A Project of the Department on the Laity of the World Council of Churches, eds. Stephen Charles Neill and Hans-Ruedi Weber (Philadelphia, PA: Westminster Press, 1963), 28-56.

${ }^{47}$ Telford, A History of Lay Preaching in the Christian Church, 13.

${ }^{48}$ David Bruce, “The Synagogue and Christ's Ministry," Expositor 9 (April 1896): 132.
} 
place of worship and community life from the "years after the Babylonian captivity." The synagogues developed in importance as a place of religious services, religious education, and spiritual training. It eventually became a substitute for the temple. Christian writer, C. Harwood Pattison, points out that the synagogue may have been the "womb in which preaching began to use Scriptures the foundation and basis for proclamations." ${ }^{50}$ This lay-led Jewish Church had given precedent for the common practice of lay preaching, of which the Christian Church was inherited. Telford states that "Judaism kept the door open for the Messiah when it allowed freedom of exhortation in the synagogue." 51

\section{NT Biblical Terminology for Lay Preaching}

The New Testament, like the Old Testament, has a treasure chest of goldenwords. These terms are rich with meaning. They capture the essence of preaching and teaching, as they coexist and collaborate to give each lay person the essence of a ministry modeled after Jesus' ministry. The main focus of to survey of NT terms is to assess whether these Greek words specifically and exclusively applied to professional clergy or applied to the larger group of believers. The NT makes use of many rich words to convey the function and activity of speaking for God. In a brief overview of words we come across terms that convey the dual meanings of "teaching" and "preaching." Words

\footnotetext{
${ }^{49}$ Encyclopedia Britannica, "The Synagogue," http://www.britannica.com/ebi/article-203307 (accessed April 11, 2009).

${ }^{50}$ T. Harwood Pattison, The History of Christian Preaching (Philadelphia, PA: American Baptist Publication Society, 1903), 10.

${ }^{51}$ Telford, A History of Lay Preaching in the Christian Church, 15.
} 
such as "apostelos," "laleo," "aggareuo," "diagello," "diasapheo," "diakonia," "apostello," "angello," "kerusso," and "evagellizo" are most known and used. Of these we will focus on Greek words of the NT that convey the concept of preaching: euaggelizo, kerusso, diakonia, diasphero.

Euaggelizo is a foundational term used in the OT for "any kind of good news of joyful tidings of God's kingdom." ${ }^{52}$ Similarly, in the NT, it refers to "the Messianic blessings ... especially of the glad tidings of the coming kingdom of God, and of the salvation to be obtained in it through Christ. ${ }^{, 53}$ This word is true to the spirit of the NT. It encompasses the most basic emphasis of the New Testament: to announce glad tidings, good news that the Messiah is here, the Kingdom of God is come, salvation is available through Jesus Christ, and redemption through the blood of the Lamb. This glad tidings is announced [euagellizo] by Angels (to Zacharias, Luke 1:19; to Mary, Luke 1:28-30; the shepherds, Luke 2:10) and disciples from Matthew to Revelation. Euagellizo is the announcement of God's glad tidings individually and collectively, to each person and people. Good news is proclaimed to all, glad tidings are given to instruct men in the things that pertain to salvation. This good news is preached [euagellizo], gospel is proclaimed as a world-wide announcement. We find this word occurring 52 times in the NT, of which it if used 10 times in Luke and 15 times in Acts.

This is word that describes the activity of two great lay preachers in the NT. Of John the scriptures said, "So with many other exhortations he preached the gospel to the

\footnotetext{
${ }^{52}$ James Strong, "A Concise Dictionary of the Words in the Greek New Testament," in The Hebrew-Greek Key Study Bible, ed. Spiros Zodhiates (Chattanooga, TN: AMG Publishers, 1991), 2379.

${ }^{53}$ The KJV New Testament Greek Lexicon, "Euaggelizo," http://www.biblestudytools.com/ lexicons/greek/kjv/euaggelizo.html (accessed March 2, 1999).
} 
people." 54 It is employed often to describe the ministry of Jesus: "The Spirit of the Lord ... anointed me to preach [euagellizo] the gospel ... to proclaim [euagellizo] release to the captives ... to set free those who are oppressed." ${ }^{, 55}$ The writer, Luke, continues to use this same word to speak of Jesus" preaching: "I must preach [euagellizo] the kingdom of God ... (4:43)," "the poor have the gospel preached [euagellizo] to them . . 7:22)," "he began going around ..., proclaiming [euagellizo] and preaching [euagellizo] the kingdom of God (8:1)." Luke continues to describe the preaching ministry of the NT Church in the book of Acts with this word. He paints a picture of the common, daily activity of the believers when he records: "And every day, in the temple, and from house to house, they kept right on teaching and preaching Jesus as the Christ. ${ }^{.56}$ It describes the ministry of believers, lay persons: "those who had been scattered went about preaching [euagellizo]" (Acts 8:4); "they believed Phillip preaching the good news" (8:12); "and were preaching the gospel to many villages of the Samaritans" (8:25); "But there were some of them, men of Cyprus and Cyrene, who came to Antioch and began speaking to the Greeks also, preaching the Lord Jesus" (11:20). Luke's confirms that preaching and announcing [euagellizo] was done by lay persons: John the Baptist, Jesus, Philip, and a wide variety of believers. This term, euagellizo, confirms their main work of announcing and preaching the glad tidings, the good news of Jesus.

Kerusso, a word used for being an official herald; one who proclaims publically, openly, the gospel-the good news of Jesus Christ. According to the NAS New Testament

\footnotetext{
${ }^{54}$ Luke 3:18 (NAS).

${ }^{55}$ Luke 4:18 (NAS).

${ }^{56}$ Acts 5:42 (NAS).
} 
Lexicon, this word is used 61 times. It is most frequently used of the first three gospels and Acts: 9 in Matthew, 14 in Mark, 9 in Luke, and 8 in Acts. ${ }^{57}$ In these accounts it means to preach and proclaim the good news with authority so hearers listen and obey.

Kerusso is a used of John the Baptist, Jesus, the Apostles, and followers of Christ. It is used in Matthew 3:1 to introduce and describe the forerunner of Jesus: "In those days John the Baptist came, preaching [kerusso] in the wilderness of Judea." It is the word that introduces and captures' a main activity of Jesus' ministry: "From that time Jesus began to preach [kerusso] and say, "repent, for the kingdom of God is at hand.".58 "Jesus was going through all Galilee, teaching in their Synagogues'and proclaiming [kerusso] the gospel of the Kingdom" (4:23). "Jesus went through all their cities and villages ... proclaiming the gospel of the kingdom" $(9: 25)$. Then, come upon the very words of Jesus, as He instructs His followers to do as He did: "And as you go, preach [kerusso], saying, "The Kingdom of Heaven is at hand"" (10:7). "What I tell you in the darkness, speak in the light; and what you hear whispered in your ear, proclaim [kerusso] upon the housetops" (10:27). Matthew also captures a touchstone command and prophecy to His disciples when He said to them (and to all disciples), "This gospel of the Kingdom shall be preached [kerusso] in the whole world as a testimony to all nations, and then the end will come" $(24: 14)$.

The Gospel of Mark, the book of action, also describes the powerful and potent activity of John the Baptist and Jesus, using kerusso 14 times. "Now when John had been

\footnotetext{
${ }^{57}$ The NAS New Testament Greek Lexicon, "Kerusso," http://www.biblestudytools.com/lexicons/ greek/nas/kerusso.html (accessed March 2, 1999).

${ }^{58}$ Matthew 4:17, NAS.
} 
taken into custody, Jesus came into Galilee, preaching the gospel of God." ${ }^{59}$ Mark also captures Jesus' directing his disciples: "He said to them, let us go somewhere else to the towns nearby, so that I may preach [kerusso] there also; for that is what is what I came for. ${ }^{\prime 60}$ Mark's gospel also tells of the twelve "He sent out to preach [kerusso]" (3:14); a leper Jesus healed "began to proclaim [kerusso] it freely and spread the good news around" (1:45) that Jesus had to leave the area; a demoniac Jesus delivered "began to proclaim in Decapolis what great things Jesus had done for him; and everyone was amazed" (3:20). Luke's gospel describes Jesus' charge to the demoniac: to go back to his home and tell what God did for him. Luke 8:39b says he went "and published [kerusso] throughout the whole city how great things Jesus had done unto him."

The book of Acts, describing the significant activity of the followers of Jesus, tells of a variety of believers and converts proclaiming the good news. "Phillip went down to the city of Samaria and began proclaiming [kerusso] Christ to them" (Acts 8:5); Paul, after his conversion, "immediately he began to proclaim [kerusso] Jesus in the synagogues . .."(9:20); Peter, preached Jesus to Cornelius and others: he tells how "he commanded us to preach unto the people ..."(10:42). Acts closes with an account of how Paul, continued "preaching the kingdom of God, and teaching those things concerning Jesus, with all openness, unhindered" (28:31). Kerusso is an important and effective verb that displays the variety of believers who Jesus used to preach the good news of Jesus Christ.

\footnotetext{
${ }^{59}$ Mark 1:14, NAS.

${ }^{60}$ Mark 1:28, NAS.
} 
Anaggello means "to announce, make known, to report, bring back tidings, rehearse." ${ }^{.61}$ This term is used 18 times in the KJV; most often in the gospel of John and Acts. This term has many forms and derivatives: angelia-the message, anangellomenactive verb, apangellomen-to declare (1 John 1:3). Another form is euagelllizo, to proclaim or evangelize the good news. Spiros Zodhiates points out that it is "almost always used concerning the Son of God as declared in the Gospel.,"62 In the Gospel of John, we are given a picture of a long-time invalid at Bethesda whom Jesus made whole. The account said, "the man departed, and told [annagello] the Jews that it was Jesus, which had made him whole" (John 5:15). Luke, in his God-given account of the activity of the early believers, also sheds light on this pattern of the common believer being the instrument of proclamation, announcing the coming, healing, and the saving power of Jesus, the Christ. "And every day, in the temple and from house to house, they kept right on teaching and preaching [euaggelizomenoi] Jesus at the Christ." ${ }^{93}$ This verse captured the way in which God worked through and among believers: it depicts the pattern"daily," the place-"house to house," the practice-"teaching and preaching," and the person of focus-"Jesus as Christ." This was God's plan that Jesus portrayed, practiced and passed on to His followers; and they did the same, all of them "kept on ... every day" the announcing, the telling, the teaching and preaching of the Gospel were being

\footnotetext{
${ }^{61}$ The KJV New Testament Greek Lexicon, “Anaggello," http://www.biblestudytools.com/ lexicons/greek/kjv/anaggello.html (accessed March 2, 1999).

${ }^{62}$ Spiros Zodhiates, "Lexical Aids to the New Testament," in The Hebrew-Greek Key Study Bible, ed. Spiros Zodhiates (Chattanooga, TN: AMG Publishers, 1991), 1727.

${ }^{63}$ Acts 5:42.
} 
done daily by all kinds of believers (old and new); in the house and in the temple, in the formal and casual places. ${ }^{64}$

Our survey of three significant NT terms has shown and established that the preaching tradition and terminology we find throughout the New Testament includes a variety of believers: leaders, like Peter and Paul, and new followers like the paralyzed and demon-possessed. These terms affirm that Jesus gave the Gospel to all, and for allkinds of believers to participate in the proclamation. Also, these terms do not indicate exclusion of any believers from proclaiming and preaching the good news, either semantically or practically. Rather it shows that words for proclaiming and preaching applied to anyone called and sent by God. Jesus called and commanded his followers to participate in the proclamation of the Good News.

\section{Jesus' Model for Training Lay Preachers}

The ministry of Jesus was a fulfillment and demonstration of the OT model of lay preaching. The Gospel of Mark records Jesus saying, "Let us go elsewhere into the next towns, that I may preach there also; for to this end came I forth. And he went into their synagogues throughout all Galilee, preaching and casting out devils." ${ }^{\text {"65 }}$ This, and other synagogue accounts, (Matt 4, 9, 12, 13; Mark 1, 3, 5, 6; Luke 4), give evidence that the preaching ministry of Jesus takes place in and among the laity. He preaches in the known place of lay preaching, he comes into ministry as a lay person, he invites lay persons to

\footnotetext{
${ }^{64}$ Pattison, The History of Christian Preaching, 58.

${ }^{65}$ Mark 1:38, 39.
} 
"follow me"

The constitutional statement of Jesus' ministry is captured by Luke, confirming that he saw himself as the fulfillment of the Messianic prophecy, and preaching tradition of the prophets and lay preachers. It fulfills the Joel 2 prophecy in principle, pattern, and person. Importantly, it fulfills and summarizes the ministry of Jesus that is to be lives out in the lives of every believer:

"The Spirit of the Lord is upon me, because He hath anointed me to preach the gospel to the poor; he hath sent me to heal the broken-hearted, to preach deliverance to the captives, and recovering of sight to the blind, to set at liberty them that are bruised, to preach the acceptable year of the Lord. . . This day scripture is fulfilled in your ears." 67

This constitution of ministry is also Jesus' synagogue address to attendees, inquirers and believers. He quotes the words of Isaiah the prophet as the model for ministry, and in this discourse he passes the mantel for preaching. John Telford refers to Josephus's historical observation, that there were "two hundred and four towns large enough to have at least one synagogue."68 This observation connects with the NT accounts that Jesus went about teaching and preaching in their synagogues. ${ }^{69}$

Jesus apparently knew the challenge and logistics of preaching in all the synagogues. Jesus' tour of the synagogues was to join the multitude that kept the holy day, filling minds and hearts with the Word of God. He knew his preaching tour was essential to his mission and ministry. Preaching was a priority, as Isaiah prophesied (Isa

\footnotetext{
${ }^{60}$ Matt 4:19; Mark 2:14; John 1:43.

${ }^{67}$ Luke 4:18-21 (KJV).

${ }^{68}$ Telford, A History of Lay Preaching in the Christian Church, 14.

${ }^{69}$ Mark 1:38,39.
} 
$61: 1-3)$, and his preaching in the synagogues strategically declared God's truth to the religious leaders and modeled the preaching ministry to unnumbered lay persons. Three times in these verses "preaching" was stated. ${ }^{70}$ Jesus told the lay persons listening to him that preaching is core to his ministry and will also be of his followers. Jesus called, organized, trained, and sent the twelve (and the seventy) $)^{71}$ to "go and make disciples." They would follow Jesus' model, patterned after the OT-lay persons trained, they train others, and those train others, and the pattern continued on.

As the OT accounts of God calling and sending lay persons to preach likewise the NT accounts of the most notable preachers being of the laity. Jesus and the twelve disciples were lay persons (not official religious leaders in Judaism) ${ }^{73}$ who did lay preaching. The new message of Christianity, the gospel, was carried so swiftly and effectively-like "wild fire"-by lay persons preaching, teaching, witnessing, and healing. ${ }^{74}$ The synagogue, by virtue of its foundation in the Judeo-tradition and culture, gave opportunity for ministry and momentum for growth of the Christian Church. ${ }^{75}$ As a sect within Judaism, Jesus and his followers were a minority. The Holy Spirit gave "different gifts" $"$ so each and everyone was empowered and involved. It was not a

${ }^{70}$ Isaiah 61:1-3.

${ }^{71}$ Luke 10:1.

${ }^{72}$ Matt 28:18-20.

${ }^{73}$ Telford, A History of Lay Preaching in the Christian Church, 16-22.

${ }^{74}$ Robert C. Worley, Preaching and Teaching in the Earliest Church (Philadelphia, PA: Westminster Press, 1967), 67, 68.

${ }^{75}$ Ibid., 66.

${ }^{76}$ Romans 12:6. 
ministry where laity sat and watched clergy minister, but one where all were lay persons did the work of ministry "as the spirit gave them." ministry of lay persons; founded upon OT purpose and design and practiced by the mandate and model of Jesus' ministry and teaching.

After its inception, as a sect of Judaism, Christianity continued as a lay movement of working men and women whose only training was on-the-job. They listened, observed and followed the examples of Jesus and the disciples. Jesus set lay persons aside "that he might send them out to preach." ${ }^{.78}$ Lay preachers kept the ministry of Jesus before everyone by their verbal witness. They kept the miracles and memories of Jesus in the forefront of the people by regularly retelling the stories. It was over three decades after Jesus' ascension before anything was written of his ministry, so these dedicated followers passed on what was etched in their hearts and minds through the ministry of preaching. These itinerant lay preachers, empowered by the same Spirit Jesus had, told the stories of Jesus-the gospel-and new followers were continually "added to the church daily. ${ }^{79}$ Christianity flourished more so after Jesus' resurrection than when he was on earth. A major reason was that his disciples taught and trained each new believer, and soon there was a host of lay preachers talking, telling, teaching, and living the life of Jesus. ${ }^{80}$ Through the lay preaching ministry the masses heard, felt and saw a living Christ.

${ }^{77}$ I Corinthians 12:4 (KJV).

${ }^{78}$ Mark 3:4 (See also Matt 10:7; Luke 9:2).

${ }^{79}$ Acts 2:47 (KJV), 16:5.

${ }^{80}$ Acts 5:42. 


\section{Notable NT Lay Preachers}

Following is a review of notable NT lay persons whose preaching captured the Spirit of Jesus' ministry and demonstrated the model of Jesus' preaching and training other lay persons.

Apostolic history is filled with pages witnessing to the significance and substantive contribution of lay preaching to the Israel's religious life. ${ }^{81}$ In the same tradition John the Baptist, the forerunner of Jesus and a great lay preacher who shook up the religious leaders in their complacency, came preaching with purpose and passion. It was the lay preaching of Jesus' followers, such as Stephen, the Apostles, Paul, Barnabas, Phillip, Peter, and the other believer, that the life and ministry of Jesus was kept before all people. By the witness of lay preachers new believers were added to the Christian Church, believers were born, disciples were taught, scriptures were searched, and the life and teaching of Jesus Christ was the focused on-the gospel was preached.

\section{John the Baptist}

John the Baptist, son of Zacharias the priest (Luke 1:5), but was not himself a trained priest. In fact he is known for his outspoken ministry and preaching against the religious hypocrisy of his day. He was an outcast of the religious system, but his lay preaching had significant following. As a lay preacher his preaching was characterized by its prophetic content, urgency, fearlessness, calling for all to "Repent ye: for the Kingdom of Heaven is at hand. ${ }^{, 82}$ Most of all John knew his purpose: "to prepare the

\footnotetext{
${ }^{81}$ Telford, A History of Lay Preaching in the Christian Church, 16.

${ }^{82}$ Matthew 3:2.
} 
way of the Lord, make his paths straight." ${ }^{, 83}$

\section{Stephen}

Stephen was a young believer who grew quickly to be a champion for Christ and his Church. When the early Church realized the need for new leaders, it selected "seven men of honest report, full of the Holy Ghost and wisdom.." records that "they chose Stephen, a man full of faith and of the Holy Ghost.... And Stephen, full of faith and power, did great wonders and miracles among the people." He championed the cause of Christ among the people and in the synagogue of the Libertines.

Acts 6 accounts many groups who came to dispute him in the synagogue (the Libertines, Cyrenians, Alexandrians, and of Cilicia and of Asia). Yet, all of them could not "resist the wisdom and the spirit by which he spoke." ${ }^{, 86}$ He was a great lay preacher who was so Spirit filled witnessing of Jesus by proclaiming his words and teachings that he stirred up the same kind of opposition Jesus and John the Baptist faced. Scripture records that after he preached to the religious leaders they were "cut to the heart, and they nashed on him with their teeth. ${ }^{, 87}$ It was this young lay preacher, Steven, who has perhaps the luminous reviews of Jewish history and longest recorded sermon in the NT-

\footnotetext{
${ }^{83}$ Ibid., $3: 3$.

${ }^{84}$ Acts 6:3.

${ }^{85}$ Ibid., 6:5.

${ }^{86}$ Ibid., 6:10.

${ }^{87}$ Ibid., 7:54
} 
fifty two verse. ${ }^{88}$ That sermon was sealed with his blood as he became one of the first martyrs. He is known as one of the greatest NT lay preachers, who, like Jesus, died with a prayer of forgiveness for his murderers. He lived what he preached.

\section{The Apostles}

The apostles were the followers that Jesus personally and specifically called to follow him. As we read the Gospels, they record the Jesus' purpose, process, and particular care in his call to them. Mark's gospel records that "He appointed twelve, so that they would be with Him and that He would send them out to preach." 89 Jesus, a lay person, selected and appointed other lay persons to join Him in preaching the "Gospel of the Kingdom." $" 90$ These twelve apostles that he called, and sent, were from among the many whom heard and accepted the "gospel of the Kingdom". Jesus was preaching. They were non-religious laborers, without religious degrees, temple training or spiritual status. $^{91}$

These apostles of Jesus were not from Jerusalem they were tradesmen and were from the country ${ }^{92}$ All four gospels, and Acts, record Jesus' entrusting the task of carrying the gospel to the world through preaching. ${ }^{93}$ Their task during Jesus' earthly

\footnotetext{
${ }^{88}$ Acts 7.

${ }^{89}$ Mark 3:13-14.

${ }^{90}$ Matthew 4:23, 9:35, 24:14.

${ }^{91}$ Telford, A History of Lay Preaching in the Christian Church, 15-21.

${ }^{92}$ Pattison, The History of Christian Preaching, 31.

${ }^{93}$ Matthew 28:18-30; Mark 16:15-18; Luke 24:46-49; John 17:20; Acts 1:7-8.
} 
ministry was to listen, observe and learn from the master lay preacher-Jesus; so not much is recorded of their preaching during this time.

\section{Paul}

Paul, whom we are so well acquainted with his many NT books (much of the New Testament writings), was also a lay preacher. He was "of the same craft ... for by their occupation they were tent maker"94 With a dramatic conversion experience-being knocked off his horse by the brightness of the Lord, blind for days, and humbled in his status-Paul is not often recognized as a lay preacher. Often said to be of the religious elite, Paul was given the best of religious schooling of his day. He employed religious learning, dramatic encounter with Christ, and filling with the Holy Spirit, to preach the kingdom of God in a different way. He employed argument, rhetoric, and his personal encounter with Jesus to argue "conceptually" for Christ. ${ }^{95}$. Paul's kind of preaching was unique from the other disciples. He was an apologist for the faith-the life, death, and resurrection of Jesus Christ. He stood in the temples of other gods and argued from their point of reference; he took the gospel to the leagues of courts of emperors, atheists and agnostics; he proposed the profound evidence of Jesus as the Christ. He preached Jesus as no other NT writer (or Bible writer) accumulatively did. His significant contribution as a lay preacher was not even how he proclaimed Jesus, but how thoroughly he made Jesus so real. His classic proclamation of the kind of love ("charity"), spoken of in I Cor 13 , is

\footnotetext{
${ }^{94}$ Acts 18:3.

${ }^{95}$ Paul Scott Wilson, A Concise History of Preaching (Nashville, TN: Abingdon Press, 1992), 24.
} 
evidence that he experienced the love of God through his personal spiritual journey with Jesus as his Lord and Savior.

This lay preacher also learned well from his direct encounter with Jesus: he made sure other disciples, such as John Mark and Timothy (his son in ministry), were taught, equipped and charged to the ministry of preaching. Paul's land-mark words to Timothy" I charge you therefore before God and the Lord Jesus Christ, who will judge the living and the dead at His appearing and His Kingdom: preach the word!"96 summons all who realize their call to preach.

His style of preaching and writing challenges all lay preachers to keep exploring "the riches of His Glory."

\section{Barnabas}

Barnabas ${ }^{98}$ is the name most used for this disciple. His real name is Joses, the Cyprus Levite. Paul, the Apostle and his partner in ministry, addresses him as "Barnabas" (the son of consolation) because of his comforting ways. ${ }^{99}$ It was Barnabas who became Paul's ambassador and bridge to introduce and connect him to the original twelve disciples. John Telford, along with other Christian historians, identify Barnabas as "the first lay preacher of the apostolic age." Telford further states the Church gave this disciple high esteem and confidence and "marked him out as the man most fitted to report

\footnotetext{
${ }^{96}$ II Timothy 4:1, 2 (NKJV).

${ }^{97}$ Romans 9:23.

${ }^{98}$ Telford, A History of Lay Preaching in the Christian Church, 18.

${ }^{99}$ Ibid.
} 
on the development of the work in Antioch, which was itself the direct result of lay preaching." 100 This lay preacher's life and sermons were characterized by exhortation and consolation. Acts 13 records the crucial role Barnabas played in the preaching of the gospel to. Scripture recognizes his as a prophet and teacher of the Church of Antioch. The church fasted and prayed and laid hands on him. The Holy Spirit led the church to partner him with Saul (apostle Paul). Barnabas is a noted lay person who preached alongside of Paul in the synagogues. He was a well known lay preacher whom the people "desired to hear the word of God" from. ${ }^{101}$ Another synagogue in Pisidia requested him "any word of exhortation for the people."102 "Paul and Barnabas continued in Antioch, teaching the word of the Lord."103 Though Bamabas is ranked as an apostle, and first known for his generosity by selling his property and giving the proceeds to the apostles, he became known for his anointed lay preaching.

\section{Phillip}

Phillip, who was also one of the seven selected by the Jerusalem church as one of the seven deacons, was successful in reaching the Samaritans with the gospel of Jesus. While the persecution from Saul caused Christians to be "scattered," disciples "went everywhere preaching the word." 104 Luke's account in the book of Acts captures a most exciting breakthrough in Christian history. "Philip went down to a city in Samaria and

\footnotetext{
${ }^{100}$ Telford, A History of Lay Preaching in the Christian Church, 18.

${ }^{101}$ Acts 13:1-7.

${ }^{102}$ Ibid., 13:14, 15.

${ }^{103}$ Acts 15:35.

${ }^{104}$ Acts 8:4.
} 
proclaimed the Christ there. When the crowds heard Philip and saw the miraculous signs he did, they all paid close attention to what he said. With shrieks, evil spirits came out of many, and many paralytics and cripples were healed. So there was great joy in that city." 105

Consider the gospel success in all the following areas: to whom Phillip was sent, the region to which he went, the reaction and reception of the people, the varied scope of his ministry, and the final result-the gospel was accepted by all who had been deceived by years of sorcery, men and women, young and old believed in Jesus Christ; and "great joy in that city." The great results of this lay preacher continued. God's angel summons Phillip to go down to Gaza, to the desert. Phillip immediately responds to the commission to go. He went and another great breakthrough unfolded. It was this lay preacher who obediently went studying with and preaching to the Ethiopian eunuch: "Then Phillip opened his mouth, and began at the same scripture, and preached unto him Jesus."106 The NT tells of a lay person who was obedient and available to the Spirit of God, quick to respond, prepared, personal, and preaches Jesus.

\section{Peter}

Peter, the brother Andrew introduced to Jesus, was a fisherman called to be a follower of Christ. As Jesus taught His disciples, Peter usually had much to say. It was after the "miraculous catch" that Jesus made a promised that stunned Peter: "fear not,

\footnotetext{
${ }^{105}$ Acts 8:5-9.

${ }^{106}$ Tbid., 8:35 (KJV).
} 
from now on you will catch men." ${ }^{107}$ With these words Jesus prophesied of Peter's preaching. It was perhaps on the Day of Pentecost that this prophetic fulfillment began. Filled with the Holy Spirit the lay preacher, Peter, opened his mouth and the historic gospel-catch occurred. His remarkable message was a historic review of bible prophecy, great oration, and Spirit-gifted preaching. This classic sermon resulted in "pierced hearts," "repentant souls," and 3,000 souls who believed and were baptized. His lay preaching reached the gentiles and reached believers such as Cornelius. Peter himself summarizes the call for all followers of Christ to preach when he states, "He commanded us to preach to the people and to testify that he is the one whom God appointed as judge of the living and the dead. All the prophets testify about him that everyone who believes in him receives forgiveness of sins through his name." 108 Peter was a great and effective lay preacher whom the Spirit of God empowered for the preaching ministry.

\section{Women Lay Preachers}

Women were also used by the Holy Spirit, during the NT time, to preach the gospel. They were effective lay preachers, though we have more account of men preaching. The New Testament Church employed their gifts in proclaiming the good news of Jesus Christ. Christian believers were well acquainted with the prophecy of Joel -its all-inclusive prophetic nature that God's Spirit would fall upon "all," "young and old," "sons and daughters" (women)."109 It is the Spirit of God that moves upon "all."

${ }^{107}$ Luke 5:10.

${ }^{108}$ Acts 10:42, 43.

${ }^{109}$ Joel 2:28. 
This includes women in the outpouring of Heaven's gift of preaching-"will prophesy ... even on your male and female servants ..."110

Women are found in both the OT and NT accounts of preaching. In John's gospel we find record of women given the ministry of the word. The Samaritan women whom Jesus met Jacob's well, being so changed and empowered by her encounter with Jesus, went back to her village and preached about Jesus. ${ }^{111}$ This was a great evangelistic event in which an entire city of unbelievers was exposed to the good news of Jesus. This lay woman preached Jesus and the result was amazing. John writes: "Many more believed because of His word; and they were saying to the woman, 'It is no longer because of what you said that we believe, for we have heard for ourselves and know that this One is indeed the Savior of the world" "112 Another account was of the good news of the resurrection of Jesus. It was Jesus who personally commissioned her to "go to My brethren and say to them, 'I ascend to My Father and your Father, and My God and your God." To this call to proclaim, we are told that Mary Magdalene announced to the disciples, "I have seen the Lord!' And she told them that he had said these things to her." 113 This account documents that Jesus, himself, giving Mary commission to proclaim the good news of His resurrection. Sandra Schneiders states that "the Spirit

${ }^{110}$ Joel 2:28.

${ }^{111}$ Telford, A History of Lay Preaching in the Christian Church, 17.

${ }^{112}$ John 4:41, 42.

${ }^{113}$ John 20:17, 18. 
called women as well as men to exercise various ministries in the Church."114 Evelyn Stagg and Frank Stagg assert that Jesus was far ahead of his time and culture. He included women and interacted with Samaritans as a norm in His ministry. ${ }^{115}$

A woman was the first disciple, lay preacher, entrusted to carry the news of the resurrected Lord to the male disciples. Mary Magdalene (and the other women) had the divine permission and authority of Jesus, the Risen Lord (Matt 28:1-10; Luke 24:1-10). The NT record account for other women who were lay preachers: Anna who prophesied in the temple, "serving night and day" (Luke 2:37). Philip the evangelist, of Caesarea, had four daughters "who were prophetesses" (Acts 21:9).

The scattered group of believers who fled Jerusalem included women. ${ }^{116}$ The Apostle Paul was assisted by Priscillia who taught Apollos. ${ }^{117}$ Paul requested that Roman Christians look out for Phebe: She was presented as one ministering (preaching) to the church." "I ask you to receive her in the Lord in a way worthy of the saints and to give her any help she may need from you, for she has been a great help to many people, including me."119 Paul's context of recommendation is that she is a fellow minister-

\footnotetext{
${ }^{114}$ Sandra Schneiders, "New Testament Foundations for Preaching by the Non-Ordained," in Preaching and the Non-Ordained: An Interdisciplinary Studty, ed. Nadine Foley (Collegeville, MN: Liturgical Press, 1983), 70.

${ }^{115}$ Evelyn Stagg and Frank Stagg, Woman in the World of Jesus (Philadelphia, PA: Westminister Press, 1978), 123-125.

${ }^{116}$ Phoebe Palmer, "The Great Army of Preaching Women," in The Company of Preachers: Wisdom on Preaching, Augustine to the Present, ed. Richard Lischer (Grand Rapids, MI: Eerdmans, 2002), 92.

${ }^{117}$ Acts $18: 26$.

${ }^{118}$ Telford, A History of Lay Preaching in the Christian Church, 19. He agrees with other historians that women were commonly serving as lay preachers.

${ }^{119}$ Romans 16:2.
} 
preacher, as he acknowledges and sends greetings to other women whom he recognized to be "workers in the Lord." 120

\section{New Testament Summary}

The review of the NT yielded much documentation of lay preaching. We have uncovered how lay preaching was connected with and continued the OT prophetic tradition and prophesy of lay preaching. The synagogues gave purpose and public place for lay preaching. It was where Jesus started his lay preaching and was his tradition and pattern of ministry to throughout the synagogues of the province. The apostles, disciples and new believers were lay persons who went everywhere preaching the good news to everyone. Jesus called and commissioned all followers to be lay preachers-proclaiming the gospel.

The Biblical account of scripture overwhelmingly records that its preachersJesus, the apostles, the Christian church leaders and great preachers-were lay persons who were called and trained in the tradition of Jesus to witness of Christ. All believers are called to be fishers of men, witnesses, messengers, primarily through the God-given and Spirit-empowered means of preaching. Broadus concurs with the biblical evidence when he says, "Lay-preaching was not an exception, it was the rule."121

As the instrument of preaching was continually employed, converts came in all ages, genders, nationalities, spiritual backgrounds, and classes. God's design of enlisting lay preachers is substantiated by the New Testament record. Matthew 24:14 records

${ }^{120}$ Romans 16:12. 1899), 47.

${ }^{121}$ John A. Broadus, Lectures on the History of Preaching (New York: A. C. Armstrong \& Son, 
Jesus' call to His disciples (clergy and laity): ${ }^{122}$ "And this gospel of the Kingdom will be preached in the whole world as a testimony to all nations, and the end will come."

\section{Chapter Summary and Conclusions}

Our survey of OT and NT Foundations for Lay Preaching has uncovered God's pattern and plan for proclaiming His word from parents to children and from generation to generation. God called common and uncommon persons to be His prophets"mouthpiece." The Biblical terminology of both OT and NT, by their context, meaning and theological implications, give accurate foundational patterns for lay preaching. Although not all lay persons preach, and not all that lay persons were noted to have preached, the biblical evidence gives a solid pattern of God using many lay persons in both OT and NT times to proclaim His Word.

In our review of scripture we observed many examples of lay persons being called and selected for hearing and speaking God's words to individuals and nations. Both OT and NT confirms God's purpose, plan and patters of making messengers, prophets, and priests of the untrained, unschooled, and non-professional (young and old, male and female, master and servant) to be His spokespersons. The "early fathers" unwittingly created a false and near fatal separation of clergy and laity that resulted in diminished effectiveness and a long-term distance between both groups of God's servants (see footnotes below.

\footnotetext{
${ }^{122}$ Although all are invited to join the community of believers in proclaiming the gospel, it must be balanced with clear Bible teaching that not all disciples receive the same gifts. So the "gift of preaching," like all other gifts, are not given to all, but "as the Spirit chooses." Ephesians 4:11-12 says of the Holy Spirit: "He gave some apostles, some prophets, some evangelists, and some pastors and teachers" (NKJV).
} 
We can conclude, from the Biblical data, that lay persons do fit the criteria as witnesses and preachers who proclaim God's Word, along with clergy and priests. The laity are indeed God's army of preachers for the ministry of preaching. Since the Biblical 
evidence, of both Old and New Testament, demonstrate God's design for lay persons to preach His Word, we can conclude that God's plan is for lay persons of these times to be His witnesses. The Biblical foundation is laid for the present-day lay preachers take up their posts as His Church fulfills the gospel commission of "preaching the gospel to every person and nation."123

Biblical foundations of the OT and NT mandate a plan and strategy that will pass on the biblical tradition of lay preaching among today's lay persons. Such plans and strategies would include models for training, enlisting and mentoring the lay person for end-time preaching ministry. This research project will demonstrate a developed model to train lay persons-a plan to build an army of lay preachers-to collaborate with clergy in the preaching ministry.

\footnotetext{
${ }^{123}$ Matt 28:19 (New Contemporary Version).
} 


\section{CHAPTER THREE}

\section{LITERATURE REVIEW OF LAY PREACHING}

This chapter reviews three areas of literature that give us a foundational, historical and current perspective of lay preaching. It survey literature on lay preaching in Christian literature, in the writings Ellen G. White, and in current literature to grasp the trends and role of lay preaching and its implications for training lay preachers today.

\section{Foundation for Lay Preaching in Christian Literature}

Christian literature forms a chorus of resounding harmony: God has spoken, is still speaking, and will continue to speak. God spoke through the prophets, translating his words and actions in history, and concurrently instructing them to pass it on; He spoke through His Son-Jesus, "The Word made flesh"; He spoke and now speaks through His Spirit, Who bear witness of Jesus, the Scriptures, and the Father. It will take a historical review, looking at the writing of The Didache, Tertullian's Apology, Justin Martyr's First Apology, Irenaeus, Eusebius-Bishop of Caesarea, John Chrysostom, Reformers-John Wycliffe, Erasmus, Luther, John Calvin, Hugh Latimer, Norman Pittenger, Neil Braun, Puritans and Evangelicals, Nineteenth and Twentieth Century writers, and elements of lay preaching that recur among them-foundational to its past, present and future: the primacy of The Word and preaching. Early church fathers unwittingly created an unbiblical separation of clergy and laity. 


\section{Post Early Church Era}

In early Christian literature the teaching, tradition, and practice of preaching was prominent. The Didache, 'Teaching of the Lord through the Twelve Apostles'dates from the beginning of the second century. It gives reference to ministries of travelling teachers, itinerant preachers, apostles and prophets. It outlines tests for true and false teachers $(11: 1-2 ; 12: 1-5)$. This was important since so many lay persons were preaching and teaching the Word of God. The risk of heresy was high and there was need to decide those who were of God. It states, "always trembling at the words which thou has heart" and "My child, him that speaketh to thee the word of God remember night and day; and thou shalt honour him as the Lord."

Justin Martyr, in his defense of Christianity from false teachers and misrepresentations, wrote the First Apology. In this work is his account of the primacy of the reading, teaching and preaching of the scriptures. He states that "all who live in cities or in the country gather together in one place, and the memoirs of the apostles or the writings of the prophets are read ... and exhorts to the imitation of these good things."2 Latin father Tertullian also wrote, in his Apology, of the meetings of Christians. In their assembly he described the reading of The Word to "nourish our faith, we animate our

l"The Teaching of the Twelve Apostles," in The Ante-Nicene Fathers, 10 vols., eds. Alexander Roberts, James Donaldson, and Arthur C. Coxe (Grand Rapids, MI: Eerdmans, 1956), 7:378.

${ }^{2}$ Justin Martyr, "The First Apology of Justin," in The Ante-Nicene Fathers, 10 vols., eds. Alexander Roberts, James Donaldson, and Arthur C. Coxe (Grand Rapids, MI: Eerdmans, 1956), 1:186. 
hope, we make our confidence more steadfast; and no less by inculcations of God's precepts we confirm good habits. ..."3

Irenaeus, Bishop of Lyons, encouraged believers to receive and adhere to apostle's teachings when he stated, "These also preserve this faith of ours in one God... and they expound the Scriptures to us without danger, neither blaspheming God, nor dishonouring the patriarchs, nor despising the prophets." Eusebius, Bishop of Caesarea and a father of Church history, condenses two centuries of the work of preachers and teachers and validates the ministry of the spoken word:

They set out on journeys from home and performed the work of evangelists, making it their aim to preach to such as had not yet heard the word of faith at all, and to give them the book of the divine Gospels. But they were content to lay the foundation only of the Faith in some foreign places, appointing others as pastors to whom they entrusted the care of those lately brought in; then they would depart to other lands and nations, with the grace and cooperation of God. ${ }^{5}$

John Chrysostom, a notable preacher and Bishop of Constantinople, was a strong proponent of the primacy of preaching for the healing and overall health of the Body of Christ. This great preacher of his time, nicknamed Chrysostomos ('golden-mouthed') and regarded the greatest pulpit orator of the Greek church, coined this healing for Christ's body as "One only means and one way of cure has been given us ... is teaching of the Word. This is the best instrument, this the best diet and climate; this serves instead

\footnotetext{
${ }^{3}$ Tertullian, "Apology," in The Ante-Nicene Fathers, 10 vols., eds. Alexander Roberts, James Donaldson, and Arthur C. Coxe (Grand Rapids, MI: Eerdmans, 1956), 3:46.

${ }^{4}$ Irenaeus, "Irenaeus against Heresies," in The Ante-Nicene Fathers, 10 vols., eds. Alexander Roberts, James Donaldson, and Arthur C. Coxe (Grand Rapids, MI: Eerdmans, 1956), 1:498.

${ }^{5}$ Eusebius, quoted in John Stott, Between Two Worlds: The Art of Preaching in the Twentieth Century (Grand Rapids, MI: Eerdmans, 1982), 20.
} 
of medicine ... this one method must be used; and without it nothing else will avail." Charles Smith wrote of how the "age of preaching" and "the history of the pulpit begins with the Preaching Friars.... They met and stimulated a growing popular demand for sermons. They revolutionized the technique. They magnified the office." It was Francis of Assisi, a man known more for his compassion and service to the needy than for his preaching, who said, "Unless you preach everywhere you go, there is no use to go anywhere to preach." ${ }^{\prime 8}$ In his major study on preaching, Between Two Worlds, John Stott summarizes the impact of Franciscan preaching: "Dominic (1170-1221) laid even greater emphasis on preaching. Combining personal austerity with evangelistic zeal, he travelled widely in the cause of gospel ... and organized his 'black friars' into an Order of Preachers. A century later Hubert de Romans said: 'Christ only once heard Mass ... but he laid great stress on prayer and preaching, especially preaching."9

\section{The Reformation Era}

Following the footsteps of the Franciscans and Dominicans, we find great reformers like John Wycliffe, the brilliant preacher/scholar of Oxford University, involved in the first English Bible, declared Holy Scripture as supreme for faith and living. In his words, "The highest service that men may attain to on earth is to preach the word of God. ... And for this cause, Jesus Christ left other works and occupied himself

\footnotetext{
TX: Word Books, 1971), 1:109.

${ }^{7}$ Charles Smyth, The Art of Preaching (London: S.P.C.K., 1953), 13-14.

${ }^{8}$ Fant and Pinson, 20 Centuries of Great Preaching, 1:175.

${ }^{9}$ Stott, Between Two Worlds, 22.
}

${ }^{6}$ Clyde E. Fant and William M. Pinson, eds., 20 Centuries of Great Preaching, 13 vols. (Waco, 
mostly in preaching, and thus did his apostles, and for this, God loved them."10 Wycliffe's views, writings, and preaching reflects the beliefs of the pre-Reformation and Reformation eras. Others like Erasmus and Thomas Moore verify the key role of preachers and preaching in the bringing about reformation. Erasmus's view of the primacy of preaching took form in his "insistence on the supremacy of the Word over sacrament, because the sacraments depend for their efficacy on their interpretation by the Word, was endorsed and amplified by Luther.

The Reformation gave centrality to the sermon. "The pulpit was higher than the altar ... without the Word the elements are devoid of sacramental quality, but the Word is sterile unless it is spoken." Calvin, too, exalted the Word of God and expressed his beliefs in the supremacy of The Word and a validation for the Church of God when he stated, "Whenever we see the Word of God purely preached and heard, it I not to be doubted, a Church of God exists ... a perpetual token by which to distinguish the Church"12 Calvin teachings of the supremacy a of the Word for all sacraments and foundational mark of the Church. Therefore, Hugh Latimer, a popular English Reformation preacher, who took clergy to task to preach the word--their most sacred task-to the people. His notable address "The Sermon of the Plough," uplifted God's word as the seed to be planted in the field of the hearts of the people. He argued that bishops and priest were "lording and loitering," so God's plan of "preaching was clean gone" $1: 234$.

${ }^{10}$ John Wyclif, Contra Fratres, quoted in Fant and Pinson, 20 Centuries of Great Preaching,

${ }^{11}$ Stott, Between Two Worlds, 23-24.

${ }^{12}$ Jean Calvin, Institutes of the Christian Religion, The Library of Christian Classics 20-21, trans. F. L. Battles. (Philadelphia, PA: Westminister Press, 1960), 1023. (First published 1536, completed 1959.) 
because "away with Bibles and up with candles, and beads; away with the light of the gospel and up with man's traditions and his laws, down with God's traditions and his most holy word." 13 His message goes on to chide and challenge the preachers to be diligent in preaching and learn from the Devil. Latimer, Luther, Calvin, and Wycliffe are examples of the belief of many during these Eras. The words E. C. Dargan gives succinct summary:

The great events and achievements of the mighty were largely the work of the preachers and preaching; for it was the Word of God, through the ministry of earnest men who believed, loved and taught it. ... And Conversely, the events and principles of the movement powerfully reacted on preaching itself, giving it new spirit, new power, new forms, so that the relation between the Reformation and preaching may be succinctly as one of mutual dependence, aid and guidance. ${ }^{14}$

Preaching's primacy and prominence was continued by the Puritans (sixteenth and seventeenth centuries)-called "Godly Preachers"15 because above all they were preachers before they were anything else. Richard Baxter is one who exemplified their ideals and consciousness that they were called to preach the Gospel and teach and train others to continue this Godly tradition. His notorious "catechizing families," which taught them to speak understand and speak the Word, and make personal progress in experiencing the Word in their lives. George Herbert, Cotton Mathers (American Puritan) and others espoused teaching and preaching of the word as a priority for pastors and laity. John Wesley also had a high and practical view of the prominence of preaching. He promoted the personal teaching and training of believers in the word

\footnotetext{
${ }^{13}$ Stott, Between Two Worlds, 27-8.

${ }^{14}$ Edwin Charles Dargan, A History of Preaching, 2 vols. (New York: Hodder \& Stoughton; G. H. Doran, 1905-1912), 1:366-7.

${ }^{15}$ Ibid., 1:357.
} 
(catechism) by his everywhere-preaching-house to house, fields, villages and churches.

\section{Post Reformation/Nineteenth Century}

The nineteenth century featured preaching proponents such as Charles Simeon, one who understood preaching as "being an ambassador of the Lord Jesus Christ," and believed that "God himself speaks to us by the preacher."16

Stott observes that this century withstood the onslaught of theories of evolution, higher biblical criticism because of the persistence and courage of English preachers like John Henry Newman, Canon H. P. Liddon, F. W. Robertson, Thomas Carlyle and Charles Haddon Spurgeon. ${ }^{17}$ Stott further captured the era with examples of powerful preachers like Father Mapple-a vivid and captivating pulpiteer: Maple speaks of how the "the pulpit is the world's most foremost part;" "pulpit leads the world."18 The twentieth century was generally filled with respect and confidence for preachers.

\section{Twentieth and Twenty First Centuries}

The Romance of Preaching, a series of lectures on preaching at Yale, delivered by Charles Sylvester Horne, there was a keen awareness of the power preachers wielded in the society as well as in the church.

Literature finds and describes the preacher going head-to-head with the businessman, the journalist, the socialist, statesman, novelist, the playwright and poet.

\footnotetext{
${ }^{16}$ Stott, Between Two Worlds, 34, refers to William Carus, ed, Memoirs of the Life of the Rev. Charles Simeon (London: J. Hatchard, 1847), 28.

${ }^{17}$ Ibid., 34-5.

${ }^{18}$ Ibid., 36.
} 
Even with the onslaught of the realities of World War I and widespread economic depression in Europe and America, "preaching gained an even greater importance than before," observes Stott. This renewed respect and confidence in the preached Word is shared by theologian Karl Barth when he said: "there is nothing more important, more urgent, more helpful, more redemptive and more salutary ... more relevant to the real situation than the speaking and the hearing of the Word of God in the originative and regulative power of its truth."19

There were non-supportive and unexpected critics of preaching who gave striking accolades to the preached word: Henry Henson said, "of all the actions of the Christian ministry preaching is the highest." ${ }^{20}$ Dietrich Bonhoeffer voiced that "In the sermon the foundation for a new world is laid. Here the original word becomes audible ... the preacher should be assured that Christ enters the congregation through those words which he proclaims from the Scripture."21 Will Sangster's, president of Methodist Conference in Britain, wrote of the preacher's task in his classic, Craft of the Sermon, "one called to preach, a herald of the great King, a witness of the Eternal Gospel. Could any work be more high and holy." R. W. Stott observes that "The tide of preaching ebbed (1960's, 70 's and 80 's), and ebb is still low today."22

In this era of growth in technology, informational growth, scientific breakthroughs and globalization, preaching may be facing it fiercest times. Yet there 4.

${ }^{19} \mathrm{Karl}$ Barth, The Word of God and the Word of Man (London: Hodder \& Stoughton, 1935), 123 -

${ }^{20}$ Hensley Henson, Church and Parson in England (London: Hodder \& Stoughton, 1927), 138.

${ }^{21}$ Clyde E. Fant, Bonhoeffer: Worldly Preaching (Nashville, TN: T. Nelson, 1975), 130. Includes Bonhoeffer's Finkenwalde Lectures on Homiletics, 1935-39. 
have been voices proclaiming the primacy of preaching yet. These voices shouted and echoed from Catholic, Protestant, Anglican, Evangelical, Lutheran, and Adventist alike. All are aware of the "trouble with preaching" but have not given up. The consensus of the religious community was of the failure to relate the gospel to the every-day world. It needed to do what it has always done: speak to the people in their language and meet them where they live.

\section{Separation of Laity from Preaching}

Throughout these centuries lay preaching brought growth, challenge and contention in most Christian denominations. The debate over the validity, role and involvement of the laity in preaching, brought continuous dialogue, lectures and books.

The early Christian church caught the mission, meaning and method of ministry by the models of Jesus and the Apostles and New Testament Christians recorded in the NT. It is no surprise that Greek words for laity, "laikos"-a derivative of laos, appears in an Epistle to the Corinthians from Clement of Rome. Its context and designation was toward the larger body of Christians, not to a select clerical group. ${ }^{23}$ Scholars such as Alan Richardson, in A Dictionary of Christian Theology, noted a new distinction of clergy and laity, in ministry function, from NT times to the Middle Ages. ${ }^{24}$ This shift

\footnotetext{
${ }^{22}$ Stott, Between Two Worlds, 43-44.

${ }^{23}$ The New International Dictionary of New Testament Theology (1979), s. v. "Laity."

${ }^{24}$ Alan Richardson, A Dictionary of Christian Theology (Philadelphia, PA: Westminster Press,
} 1969), 187, 188 . 
from ministry being a collective lay collaboration, where ordinary lay person understood all aspects of ministry (including preaching) as their calling, to preaching being defined as clerical activity and beyond the bounds of laity, is a major mark of the post-apostolic era.

The shift from Apostolic to post-apostolic era gives rise to new emphasis: Von Campenhausen states that the first missionaries were not seeking to "found churches but to proclaim Christ" by their witness, testimony and preaching. ${ }^{25}$ The new era finds the emphasis of the clergy being on finding churches and promoting distinction of clergy and laity-far from the mission and method of Christ and the Apostles.

Both history and literature trace the widening gap of clergy and laity in ministry. T. Harwood Pattison in The History of Christian Preaching, identifies as significant factors for the laity-clergy distancing and separation in ministry: (1) the clergy assumed "preaching as their primary right by training and vocation," (2) the institutional church restricted lay preaching "as the leadership of the church increasingly utilized proclamation as means of reinforcing the structures of clerical control. ${ }^{, 26}$ The growing ministry dysfunction is captured by Mark Gibbs and T. Ralph Morton: "The congregation has developed a structure that depends entirely on the minster. The life of the congregation has grown up around him and depends on him. ${ }^{.27}$

Edward Schillebeeckx addresses the issue in his article, "The Right of Every

\footnotetext{
${ }^{25}$ Hans von Campenhausen, Ecclesiastical Authority and Spiritual Power in the Church of the First Three Centuries (Stanford, CA: Stanford University Press, 1969), 55.

${ }^{26}$ Pattison, The History of Christian Preaching, 396.

${ }^{27}$ Gibbs and Morton, God's Frozen People, 49.
} 
Christian to Speak in the Light of Evangelical Experience 'In the Midst of Brothers and Sisters," believes it was "a struggle for authority ... formation of 'roles' . . as part of system differentiation, frequently even as a justification of historically acquired positions of power or monopoly."28 Pattison adds that ecclesiastical arrangement of word and sacrament were strictly controlled. The Luther-led Reformation did not overturn the clergy persistent control of preaching while other ministries of the Church seemed to enjoy shared participation, but rarely was the God-given ministry of preaching shared with laity. ${ }^{29}$

This monopolizing of preaching by clergy and the devoicing of the laity by the institutional church steadily grew from early centuries, and led to centuries of struggle and debate concerning the rightful place of laity in preaching. Other books and publications of the twentieth century trace and shed light on the clergy-laity conflict over the ministry of preaching. The lay preaching debate within the Catholic church engaged the best of priests and preachers, theologians and lay persons. Thus books such as The Laity, Church, and World: Three Addresses by Yves Congar (1957), The Mind of the Catholic Layman (1960), The Emerging Layman: The Role of the Catholic Layman in America (1962), The Church and the Laity: From Newman to Vatican II (1965), and Papal Power: A Study of Vatican Control over Lay Catholic Elites (1980), give insight in the struggle and debate over lay preaching in the Catholic church. Other books such as The Modern Apostle (1957), Layman in the Church (1962), The Church, the Layman, and

\footnotetext{
${ }^{28}$ Edward Schillebeeckx, "The Right of Every Christian to Speak in the Light of Evangelical Experience "In the Midst of Brothers and Sisters,"' in Preaching and the Non-Ordained: An Interdisciplinary Study, ed. Nadine Foley (Collegeville, MN: Liturgical Press, 1983), 11.
} 
the Modern World (1959), Protestant Hopes and Catholic Responsibility (1960), The Role of the Laity in the Church (1956), The Lay People in the Church: A Study for a Theology of the Laity (1957), The Laymen's Call (1942), wrestle with the balance of the rightful place of laity in preaching and the leadership clergy must give for the partnership, and shared ministry Jesus instituted, to continue.

During these decades preaching, proponents such as Donald Coggan, whose passion for preaching was contagious and Dr Martyn Lloyd-Jones in his book, Preaching and Preachers (1971), waved the banner for the "primacy of preaching" and the place of whole body in the holistic ministry of Jesus.

This historical sketch of preaching in Christian literature, the growing separation and elimination of laity from preaching has given us a panoramic view of the importance of preaching in a twenty century span-from Jesus to the 1970's and 80's. Of significance is the consistent priority and prominence of preaching in the Christian tradition, and the biblical mandate for the "whole body"-clergy and laity to be involved in the ministry of proclamation. In spite of the changes and challenges of each era, the religious divisions and denominational walls, preaching has held its ground-not without its ups and downs. Yet, through all the struggles and battles, preaching champions have stood tall in each century; preaching has come through as gold "tried in the fire"-only better, stronger, and purer.

\section{Foundations for Training Lay Preachers in Current Literature Review}

This review seek to examine current and contemporary literature that embraces

${ }^{29}$ Pattison, The History of Christian Preaching, 398. 
the ministry of lay preaching by its biblical-based theology, its teaching and training methods and practices, and models that are implemented or to be implemented for present-day ministry. Thorough and significant work has been done in the larger field of "lay ministry," limited work has been done in the area of training lay persons to preach, ${ }^{30}$ and even fewer models exist for literature review and field implementation.

Evaluations of literature and research of what has been done in the past, show a dirth of written material to aid the pastor to fulfill this task and tackle this problem in ministry. This is the "tip of the ice berg" to the ministry problem. Pastors play a significant and pivotal role in training laity. As pastors grapple with this problem, conferences also are beginning to grasp the enormity of the need in helping their pastorsladen with large districts and limited members to lead-to find suitable methods to train lay persons to join pastors in the preaching ministry

There is no curriculum to teach and train lay persons for preaching ministry (as exists for other ministries such as outreach/witnessing, health ministries, children's ministries, etc). Little of or resources have been gathered in an organized form or resource book and made available to laity. There are no approved and applied working models for church-wide usage as a standard to follow in training lay preachers. Also, since many lay preachers feel unprepared, and know they have little or no training, they are unmotivated to step up and fulfill their God-given commission. When the laity receives proper training they will be stirred to step up and preach. Likewise, many

\footnotetext{
${ }^{30}$ Nadine Foley states, "It has become evident that little formal study of the office of [nonordained] preaching, its historical development, and its presumed integral relation to the role of the priest [professional clergy] ... has been done" (Foley, 3-5). Floyd Breeze, Rex Edwards, Mark Gibbs, Richards, Martin, Taylor, and many others conclude that literature in the field of lay preaching is "scarce indeed." .
} 
pastors are frustrated and avoid starting lay training to preach knowing the dirth of effective materials and workable models.

Howard Grimes, in The Rebirth of the Laity, tackles the subject of lay preaching and the question of re-enlisting laity in ministry. His grasp of the Laos being the pool of ordinary people from which God chooses, anoints and appoints for the work of ministry. ${ }^{31}$ The contribution of Grimes work is its theological foundation for the place of every lay person (believer) in God's master plan of ministry. He gives us a review of the variety of theories of laity and aids us in sorting through their theories and presuppositions.

The Modern Apostle is a unique work by Louis Joseph Putz. The writer lays out a sound biblical understanding and how traditional understanding of spiritual and ministry roles do apply to laity and can be carried out in their daily lives. This work first establishes the mission of the laity: "vocation"-how God calls laity to action and service, "Apostolate"-building up and growing of believers, "dedication"-sacrifice, service and servant-hood. Then it sets forth the ways laity can express service: family and community, students and youth preparation, the work and the aid of the Holy Spirit, and the layperson as a pastor (lay-parish priest). The final section is profound in how it demonstrates all the fore-said elements in the life of Jesus: His preparation-how it forecast our "times of silence," "hearing. His voice," "facing tests and temptations" and "surrender to His authority"; 32 His expectation-our faith forming anticipation for God's

\footnotetext{
${ }^{31}$ Howard Grimes, The Rebirth of the Laity (New York: Abingdon, 1962), 14.

${ }^{32}$ Louis Joseph Putz, The Modern Apostle (Chicago, IL: Fides Publishers, 1957), 39-42.
} 
work in and through us; His transfiguration-living out the kingdom daily, the cross and His second coming, and experiencing God daily as a foretaste of Heaven. This is a work that engages the lay person by its inclusion of laity in ministry theology and practice, thereby establishing their role as preachers of the gospel.

A writer who gave a thorough teaching of the theology and practice of the laity was Yves Congar. He addressed the current problem and the historical factors in his masterpiece, Lay People in the Church: A Study for a Theology of the Laity. Facing the issues head-on, Congar stated that "laity was never ordained by God to be so passive a light" and the biblical example called for total ecclesiology."33 This work goes deep into the meaning of "layman"-probing the words "kleros and laos in the Bible; exploring the distinction of clergy and laity in early Christianity. Congar brings in "the blurring of the distinction between cleric and monk," the "monastic notion" of the twelfth century and the "canonical notion" 34 ' of the thirteenth century. This book soundly speaks to and of the "priesthood of believers" in terms of the "laity functioning as priests-priesthood of the faithful. ${ }^{\prime 35}$ Congar faithfully connects the layman to every aspect of the church and ministry in functions of priests, king, and prophet. The author has theologically and practically shaken the historical separation of the laity from the clergy. The words, "The laity are the Church and make the Church not by being subjects of the hierarchical

\footnotetext{
${ }^{33}$ Yves M. J. Congar, Loy People in the Church: A Study for a Theology of the Laity (Westminister, MD: Newman Press, 1957), 24-30.

${ }^{34}$ Ibid., 3-9.

${ }^{35}$ Ibid., 123, 181 .
} 
mission . . but by having part in the dignity of the body of Christ. ${ }^{\$ 36}$

Francis O. Ayres in his work, Ministry of the Laity, argues for the ministry of laity to be just as significant as that of the clergy-for they are both out of the "laos"-the pool of God's people. His theology is that clergy-the pastors, share their calling and functions with the laity-the ministers. Both clergy and laity are "servants to the world." ${ }^{37}$ Clergy are admonished to share ministry (equally) with laity, and he challenges laity not to settle for "add-on," and "second-class citizen" positions. His work is a high calling to laity:

"You are a minister." ${ }^{38} \mathrm{He}$ calls all laymen to action, ministry and passion-as demonstrated and modeled in the book of Acts.

A more recent work, A New Frontier: Every Believer a Minister is contemporary contribution of Rex Edwards. He addresses the mission given the Christian Church to train and empower its members to be the "priesthood of all believers." This is done by the movement and methods used by the early church of the first centuries to foster involvement and participation of each lay person in church's mission. ${ }^{39}$

God's Frozen People is a striking title for a fascinating work-a landmark in laity literature. Mark Gibbs and T: Ralph Morton joint authorship (a collaboration of a clergy and a layman) is a face-to-face confrontation to hostage position laity have been placed in for centuries. The institutional church is charged with a "crippled ministerial

${ }^{36}$ Congar, Lay People in the Church, 430, 31.

${ }^{37}$ Francis O. Ayres, The Ministry of the Laity (Philadelphia, PA: Westminister Press, 1962), 15.

${ }^{38}$ Ibid., 31,75 .

${ }^{39}$ Rex Edwards, A New Frontier: Every Believer a Minister (Mountain View, CA: Pacific Press, 1979), 25-50. 
dependency." ${ }^{40}$ Their emphasis is that the structural system is self-defeating. A system that goes contrary to what Jesus and the Apostles launched that took the world by storm. Gibbs and Morton are saying, "let's get back to the original plan of ministry!"41 Their solution is Jesus' model of collaboration of the clergy and laity; so they challenge the clergy: "The minister holds the key to this, because he has the responsibility for the conduct of worship, and therefore the responsibility of finding meaning for greater, and effective lay participation in worship. This is what it means to say that he 'leads' the worship of the church." ${ }^{42}$

Specific works that address the subject of involving and training lay persons to preach are germane to this study. This is the fresh stream of change and flow of ministry from the lives of laity. Each work and project makes a progressive step toward preparing laity for their place in preaching ministry. In this vein Douglas Gwyn has put together a solid work of how to teach members to preach for worship, "A School of the Prophets: Teaching Congregational members to Preach," in Preaching in the Context of Worship. His writing is for the purpose providing a training course, a manual to help members develop and preach sermons. This is where all the historical and theological literature is to lead-getting lay persons back to preaching. ${ }^{43}$

Lay Ministry: Empowering the People of God is a joint effort by Lawrence

${ }^{40}$ Gibbs and Morton, God's Frozen People, 49-50.

${ }^{41}$ Ibid., 112.

${ }^{42}$ Ibid.

${ }^{43}$ Douglas Gwyn, "A School of the Prophets: Teaching Congregational Members to Preach," in Preaching in the Context of Worship, eds. David M. Greenhaw and Ronald J. Allen (St. Louis, MO: Chalice Press, 2000), 99-105. 
Richards and Gilbert R. Martin. Their contribution to lay ministry and lay preaching is found in the angle they take on the subject. Their aim is to get the Church to refocus on Christian identity and giftedness by the Holy Spirit. This is what makes this study of such interest and yet so easily overlooked because it is right before us; and we tend to overlook what is closest to us. Their approach to lay ministry is based in the relationship we have with God-our Father, Jesus-our Savior and example, and the Holy Spirit-our helper and power. ${ }^{44}$

Nancy Taylor has ventured in a known path, but in a unique way. Her project, "The Work of the People: From Silence to Faith Proclamation"-published in the Chicago Theological Seminary Register, is of a deliberate and collaborative ministry-project of clergy and laity in planning worship by teams, with the leadership of the pastor. Both laity and clergy plan and preach, equally sharing the responsibility and joys of planning, preparing, testing, and preaching. ${ }^{45}$ It is a holistic approach to the complete worship service. What it lacks (which may just have been omitted in the writing and description) is the preparing of the laity for these roles-planning worship, preparing, preaching-by the clergy with any training or specified workshops given over time to arrive at this point of collaborative clergy-laity ministry.

Heralds of God's Word: Lay Preaching Seminar Textbook is a work by Mike Stickland. It was born out of the preaching course a pastor taught his lay preachers. It has "class notes, worksheets, and lesson assignments" that form a practical curriculum for

\footnotetext{
${ }^{44}$ Larry Richards and Gilbert R. Martin, Lay Ministry: Empowering the People of God (Grand Rapids, MI: Ministry Resources Library, 1988), 185-235.

${ }^{45}$ Nancy Taylor, "The Work of the People: From Silence to Faith Proclamation," The Chicago Theological Seminary Register 87 (1997): 10-42.
} 
helping the lay preacher. It is not a thorough training guide, but is a first-step to help the lay person in a very general way. The seminar covered areas of sermon topics, structure, persuasion, communication principles. ${ }^{46}$ This is personal and practical response to the need of laymen who wanted help in preaching. More can be done to make this a more complete and thorough training program, yet it is a start that many pastors need to make, a step they need to take.

One of the first hands-on projects that specialized in teaching lay persons to preach is The Lay Preacher and His Work. The focus is to give laity helpful tips and biblical encouragement to learn and get involved in preaching. It reminds laymen to see themselves "as heralds of their King's message ... to lift up their voices before assembled bodies of men and women. They are to persuade men, both in public and from house to house, to repent and believe., ${ }^{, 47}$ This work provides basics for lay persons on how to lead others to Christ and some how-to on preaching.

A scholarly sound and intellectually stimulating work is Preaching and the Nonordained. This work is set apart by being a collection of papers given at a symposium of the Dominican Leadership Conference, 1982, in Ohio. The individual contributors to this collection each bring a building block to the need and a needed ministry paradigm for lay preaching. Together these voices for lay preaching created a harmonious chorus of biblical, historical and theological rationale that will affect clergy and laity for years to come. A highlight of this collection is the contribution of Schillebeeckx, when he gives

\footnotetext{
${ }^{46}$ Mike Stickland, Heralds of God's Word: Lay Preaching Seminar Textbook (Silver Spring, MD: Ministerial Association, General Conference of Seventh-day Adventists, 1998), 4-6.

${ }^{47}$ Home Missionary Dept., General Conference of Seventh-day Adventists, The Lay Preacher and His Work (Nashville, TN: Southern Publishing Association, 1940), 10.
} 
three criteria for who has the right to preach: evangelical life-converted by the gospel and encounter with Christ, theological competence and effective training, and preaching authorized by local church authority. ${ }^{48}$ Sandra Schneiders, another contributor to Preaching and the Non-Ordained: An Interdisciplinary Study, clarifies the NT evidence that ascertains no exclusion of any group of believers "from any dimension of the ministry of the Word." 49 She further admonishes that "The central concern of those who have responsibility for the ordering of ministry in the community must be that the Word not be bound or silenced for the sake of human traditions, much less for the protection of titles ... but the Word must be preached ... until the gospel has indeed been proclaimed to every creature. $" 50$

Preaching and the Non-Ordained, has given us a thorough collection of theological foundations for lay preaching. It speaks to the sensitive debate among Catholics, the participation of women in preaching, and addresses the issues that all denominations and Christians are facing concerning lay preaching. It tackles the urgency of the issue in light of the health of the Christian Church. It affirms the place of all believers-" "the laos"-in ministry, the God-given, Christ-commissioned status of every believer proclaiming the gospel. It gives the beat to which others can march forward in the lay ministry of preaching.

Lay Preacher's Manual: Instructions in the Principles and Methods of Public Evangelism is a good manual for getting lay preachers interested and started in the basics

\footnotetext{
${ }^{48}$ Schillebeeckx, "The Right of Every Christian to Speak," 16-32.

${ }^{49}$ Schneiders, "New Testament Foundations for Preaching by the Non-Ordained," 85.

${ }^{50}$ Ibid., 86.
} 
of preaching. This manual is set up to empower lay preachers for evangelistic sermons and other preaching resources. It gives a high dose of encouragement and opens the door of evangelistic enlistment to the lay persons by quoting Henry Ward Beecher: "Men ought to preach the gospel who do not make preaching their profession.... It is preposterous to think of waiting until we have what is called a thoroughly educated ministry. ... Any man in any business who loves God and man, and has opportunities and gifts, should preach-and not occasionally, either, but often." ${ }^{\text {,51 }}$ This work not only educates and encourages, but it maps out the process of preaching by giving substantial resources for the developing, preparing, organizing, and delivering of evangelistic meetings. It also challenges the clergy by giving meaningful mandate to motivate, train and equip the laity for the ministry of preaching. Like many of the other how-to works and manual-like publications, the missing ingredient is the lack of biblical, historical and theological foundation that is needed for thorough training and equipping of laity in preaching the Gospel.

Steve P. Vitrano contributes two works, So You're Not A Preacher! A Lay Leader's Guide for Sermon Preparation and How To Preach: A Practical Guide to Better

\footnotetext{
${ }^{51}$ Home Missionary Dept., General Conference of Seventh-day Adventists, Lay Preacher's Manual: Instructions in the Principles and Methods of Public Evangelism (Nashville, TN: Southern Publishing Association, 1934), 16 .
} 
Sermons. In these two works Dr. Vitrano purposefully and practically designed to help the lay person preach for worship. Its approach is laid out orderly and worded with simplicity. His prerequisites for the layperson are: prayer and preparation, consecration and clarity. ${ }^{52}$ In encouraging lay preachers, Vitrano says: "When you prepare to preach, you do not prepare alone. The spirit is present to guide you and to illuminate your mind so you may understand God's Word. He [God] is as present during the preparation of your sermons as He is when you preach it." ${ }^{, 53}$

Floyd Bresee's booklet, Successful Lay Preaching, is a small but comprehensive and successful guide. Bresee condenses the theological, the NT foundations, and Jesus' mandate. He observes how laity have been removed from the pulpit, and yet contrasts how "little or no training" they have. Bresee spells out important advantages to the church of having lay preachers for effective witness to the world-advantages both clergy and church institutional leaders are reluctant to face. Jesus' method, the apostles' ministry and the early Churches' mission knew that lay preachers naturally have more credibility with the world. This booklet guides the lay person suggesting that this is a start and not the end of the lay preaching journey. Bresee does not suggest or give a preaching model to clergy or laity, that's the missing ingredient.

An effective guide and model by Maylan Schurch, Help! I've Been Asked to Preach: Don't Panic... Here's Practical Help to Keep Your Sermon from Sinking, is for

\footnotetext{
${ }^{52}$ Steven P. Vitrano, So You're Not A Preacher! A Lay Leader's Guide for Sermon Preparation (Washington, DC: Review and Herald, 1977), 3. Steven P. Vitrano, How To Preach: A Practical Guide to Better Sermons (Hagerstown, MD: Review and Herald, 1991), 7.

${ }^{53}$ Vitrano, So You're Not A Preacher!, 12.

${ }^{54}$ Bresee, Successful Lay Preaching, 11-13.
} 
the busy layman. It keeps it simple, but is a thorough and practical 'nuts and bolts' approach to the subject. Schurch uses good device to help the lay preacher: The "SPICAT is for: Scripture Point Illustration Comment Application Transition." 55 The author gives a balanced, holistic model to prepare lay preachers. In it he not only gives the practical nuts-and-bolts, but lays the spiritual foundation by teaching laity the importance of the spiritual life. Lay persons are given "how to get and stay spiritually fit" steps: recommit to Jesus, daily devotion schedule, evict known sin, and pray about your sermons. ${ }^{56}$

Two works that have made significant contribution to the historical, spiritual and practical aspects of training lay persons to preach are Frank Ottati's, $A$ Training Seminar for Preaching: Developing Effectiving Preaching Skills, and Victor V. Dyman's, Holistic Approach to Preaching: A Training Program for Lay Speakers of Manhattan Seventhday Adventist Church. Both these contributions to the field add to previous foundational works, but they also chart new territory in the dynamic debate of the right and role of laity in preaching the gospel in these "last days."

Ottati's work, A Training Seminar for Preaching, outlines the theological, practical, and spiritual journey of lay preaching. He uncovers grow and the core areas of preaching a maps out the stages and steps lay persons must take to develop into effective preachers. He identifies the culture and needs of laity, then challenges clergy and church structure and leadership to focus making proclamation a shared ministry with laity.

\footnotetext{
${ }^{55}$ Maylan Schurch, Help! I've Been Asked to Preach: Don't Panic. Here's Practical Help to Keep Your Sermon from Sinking (Hagerstown, MD: Review and Herald, 2007), 12-14.

${ }^{56}$ Ibid., 25-28.
} 
Ottati's work is one which doesn't so much diagnose the problem, but presents a well constructed solution. The foundation of his seminar is based on the Bible mandate for clergy (pastors) to "equip" laity. He states that "Laity are willing to do their share in the God-given responsibility to the church." ${ }^{, 57}$ This project is an important effort in mobilizing laity for the ministry of proclamation. He cites Ellen White's words: "... the great purpose of the teaching ministry is not to tie our pupils to our apron-strings, but rather to help lead them into spiritual maturity and active ministry," to pastors and church leaders. This work poses a solution to a big problem. I admire the courage to go much farther than analysis of the problem to set a structured and practical program with clear steps for lay persons to learn, develop and become effective lay preachers for a shared ministry (with clergy).

Ottati carefully and realistically points out a reasonable path to teach lay persons to preach. He quotes E. G. White as saying, "Many would be willing to work if they were taught how to begin. They need to be instructed and encouraged... It is training, education, that is needed. . ."59 This seminar strategically starts with Jesus' model of preaching. It takes the lay person on a course of understanding preaching from the perspective of Jesus and the Gospel. The author outlines the preaching ministry of Jesus. He notes that "The only place to begin is with Jesus himself." ${ }^{, 60}$ This seminar also gives the lay person the biblical background of preaching, the preacher, the message, and how

\footnotetext{
${ }^{57}$ Frank Ottati, A Training Seminar for Preaching: Developing Effective Preaching Skills. D.Min. dissertation, Andrews University, 1998. 32. p. 50,51 :

${ }^{58}$ Ellen G.White, Gospel Workers (Washington, D.C.: Review and Herald Publishing Assn., 1942,

${ }^{59} \mathrm{Ibid} ., 150$.
} 
important the lay person is in God's proclamation plan; and how all these work together uplift Jesus and "draw all men to Him."

This work gives a mandate for clergy to return to their calling-to train and equip laity for the work of ministry, to be the coach and lead members to get in the game and play their God-given position. It is a liberating word for laity, releasing them to live out their calling to proclaim the good news.

Victor Dyman, in Holistic Approach to Preaching, establishes a biblical, theological, and practical approach to lay preaching-the "holistic approach." His biblical survey of both the OT and NT uncovers the rich biblical treasure chest of the Word of God, "the power of God's Word," and "the desire to make His Will known." His survey of both OT and NT are user-friendly for lay men, and yet were interesting for professional clergy to get a fresh exposure to God's original plan for preaching.

His project takes a new path and blazes new trails for lay preaching, specifically, and preaching in general. Of particular significance is his treatment of The "Challenges of Lay Preaching, in chapter three. This work opens the eyes of clergy and laymen, alike, to the many real obstacles, walls, and fortresses to the proclaimed Word. He alerts preachers to the "secular mind," "silent generation," "generations $\mathrm{X}$ and $\mathrm{Y}$, ," "the electronic media," but also poses implications for preaching to these groups and mindsets.

Beyond the challenges, Dyman pushes preachers to consider how to respond to all these challenges by "holistic preaching"-preaching that delivers "personal authenticity" through spirituality; preaching that delivers "accuracy of interpretation"-through

${ }^{60}$ Ottati, 56. 
observation, interpretation and application of the text; preaching that allows for "audience adaptation"-giving practical strategies to read, relate, and reach the audience. ${ }^{61}$

This research, of Dyman, confirms four key points about preaching: "(1) preaching is God's preferred method of revealing Himself to humanity; (2) most commonly used Hebrew and Greek words ... were not applied to the call of professional temple ministers, but ... describe the communications of ordinary lay individuals; (3) the majority ... God called and commissioned to speak ... carried out without formal training ... (4) authority to preach comes from God Himself . . making lay members eligible for preaching.. ${ }^{.62}$

Dyman has given us a significant and sound model that will support the work of clergy and assist lay persons to developing their understanding of preaching, helping them to be effective messengers of God's Word. The author gives accurate diagnosis to the main problem of lay preaching when he says, "the inadequacy of the training which lay preachers typically receive is obvious. Poor, disconnected preaching discourages both the listener and the speaker." ${ }^{\prime 63}$ This project is a solid plan that exposes lay persons to the entire scope of preaching: the personal spirituality of the preacher; the theological basis and foundations for preaching and its role in God's master plan, the cultural challenges to the preacher and the preaching event, the communication barriers and break-through steps, and the practical disciplines that make great preachers, powerful and effective communicators of God's Word.

\footnotetext{
${ }^{61}$ Victor V. Dyman, "Holistic Approach to Preaching: A Training Program for Lay Speakers of Manhattan Seventh-day Adventist Church" (D.Min. thesis, Andrews University, 2008), 134-49.

${ }^{62}$ Ibid., 93, 94.
} 
Dyman also calls lay preachers to self examination with these biblical/spiritual values that God has always held as a litmus test for his servants: humility, love, integrity, spirituality, nurture, communication, leadership and mission. These qualifications and many others steps are effectively organized into questionnaires, and forms for the lay preacher and pastor/teacher to use.

He further points out that a holistic model of preaching "is a fruitful area for future research" and that there needs to be "application of the research to the needs of the local congregation and lay speakers." ${ }^{64}$ He also points out that much listening and learning needs to be done by pastor/teachers who facilitate the training of lay persons. He recommends to clergy and facilitators: (1) to be aware and open to revisions to you model and plan; (2) future use of the format consider the needs and schedules of the participants; (3) professional and spiritual mentoring needs to be planned and prepared for by clergy; (4) an emphasis on spirituality should allow the technical and practical to be aspects of preaching to merge with it; (5) reconfiguration of material is needed so that the preaching participants focus on their spirituality - relationship with the 'Word' Himself; (6) future lay preaching training to give more time for students to absorb each major concept of holistic preaching; (7) professional clergy may consider to enroll themselves in a workshop like this to realign their understanding and restore their passion for preaching. ${ }^{65}$

Dyman may consider three elements in training laity: (1) formatting its model

${ }^{63}$ Ibid., 3.

${ }^{64}$ Dyman, "Holistic Approach to Preaching," 292.

${ }^{65}$ Ibid., 292-94. 
to consider the needs for recurring seminars for those who did not participate;

(2) continuing seminars for further training growth-spreading the material out over a 2-4

seminar/workshops; (3) have the presenter/facilitators take a class or workshop in "adult education," "adult learning" to be prepared to format and approach the teaching of the preaching material for maximum learning. It may be further observed and stated that many pastors have not been trained to teach and train adults, yet this is the make-up of their membership, audience, and team.

This project is a wealth of information which will give pastors and members the tools needed to bring lay preaching back to its powerful and effective state we find in the lives of the prophets, the witness of the NT believers and the preaching of the apostles.

\section{Foundations for Training Lay Preachers in the Writings of Ellen G. White}

The purpose of the survey of Ellen White's writings is: (1) to explore her concept of the role of lay persons in the work of ministry; (2) to examine her differentiation between pastoral preaching and lay preaching; (3) to examine her counsel on training lay persons to preach; (4) to identify her counsel on how clergy and laity can collaborate in the preaching ministry. In her book, Acts of the Apostles, she encourages the fulfilling of the great commission of Matt 28;19 and the preaching of the gospel to the world. She then appeals to the "thousands of consecrated lay members" to join the ordained minister and carry out the gospel commission. ${ }^{.66}$ In principle, direct teaching, and in practice, White affirms the legitimate and essential role for lay preaching 1911), 111 .

${ }^{66}$ Ellen G. White, Acts of the Apostles (Mountain View, CA: Pacific Press Publishing Assoc., 


\section{A Brief Historical Sketch}

Ellen G. White held a high concept of the role of the lay person in the work of ministry. She was a lay person, and perhaps the most celebrated lay person of the Advent movement in her day, and even to the twentieth first century. She was part of the lay movement of the historic 1844 message and people awaiting the imminent return of Christ. She was a young girl who joined the lay bible studies and lay movement of William Miller-a lay Bible student and preacher who believed Jesus' second coming was going to be October $22,1844 .^{67}$

Ellen White was an integral part of the great Advent Movement, led and founded by lay persons. She was used of God to minister as a lay person through dreams and visions. These gave evidence of God's leading to alert the world to His "last-day message" and of His soon return. This lay-led movement was a way of life for Ellen White, her husband, James White, and thousands of laymen who brought the study of God's Word and the prophetic emphasis of end-time event back to mainstream America. Their commitment to God, hunger for understanding His prophetic Word, team work and untiring zeal created a momentum of lay-founded ministry that had a world-wide impact.

\section{Concept of the Role of Laymen in Ministry}

Throughout the history, life and ministry of Ellen G. White, she had much to say about the importance the laymen in carrying out and completing the commission of Christ to "preach the Gospel to all the world ... and then shall the end come" (Matt

\footnotetext{
${ }^{67}$ George R. Knight, Millennial Fever and the End of the World: A Study of. Millerite Adventism (Boise, ID: Pacific Press, 1993), 71.
} 
28:19,20). Her writings, counsels, teaching, and preaching reflects her high regard for God's plan that laymen are His ministry soldiers. Over her life span her beliefs and teachings on this subject grew both in depth and volume. ${ }^{68}$

Her writings, teachings, and sermons, together give a summary of her biblical and theological belief of the role of the lay person in ministry. Not only were her belief a natural growth of her personal experience, but was the subject matter of many counsels to the church during her personal and prophetic ministry; that of her extensive works of seventy books and over 60,000 pages of manuscripts. This study is not an extensive examination of all her works but a brief sample of statements that reflect the general body of her writings. Attention is given to the great significance she placed on the pulpit, asserting its divine sanction and ecclesiastical importance. Her words, "There is no department of the work of God but that is as constantly under the eye of God as is the preaching of the word," $" 69$ to Edson, her son, in 1875, is consistent with many other statements to confirm her high belief in the importance of the preached word.

\section{Differentiation of Pastoral and Lay Preaching}

In considering Ellen White's view of preaching, and if she differentiated between pastoral preaching and preaching by lay men, this study does not find any substantial statements or teaching in her writings, or other sources of her teachings and belief that speaks to a difference in preaching of pastors and laymen. What was discovered was

\footnotetext{
${ }^{68} \mathrm{R}$. Edward Turner, Proclaiming The Word: The Concept of Preaching in the Thought of Ellen $G$. White (Berrien Springs, MI: Andrews University Press, 1980), 15-18.

${ }^{69}$ Ellen G. White to J. E. White and Emma White, 10 September 1875, Letter 32, 1875, Center for Adventist Research, Andrews University; Berrien Springs, MI.
} 
what she said on the following areas of preaching: authority of the pulpit, the purpose of preaching, the function of the sermon, the source of the preacher's message, length of sermons, humor and sensationalism, set discourses and extemporaneous preaching. ${ }^{70}$ Turner's analysis of her preaching, and the preaching of her times, concluded that "Ellen White's concept of the authority and purpose of preaching was common to the prevailing homiletical theory of her time"-preaching is God's ordained method of the saving of souls. Even during the early part of the twentieth century, when the effectiveness of preaching was questioned and the pulpit seemed to be in deep trouble with cultural changes, secular reform and the increase in higher learning, White embraced preaching as God's divine plan for the edifying of the body and propagation of the gospel. It was during this time that she penned most of her writings on the authority of the pulpit and purpose of preaching. ${ }^{71}$

\section{Concept of Training Lay Persons to Preach}

Ellen White's view and approach to training lay persons to preach was tied to her deeply held beliefs and passion for training lay persons for all areas and aspects of ministry. What stands out is her concepts of "training schools," "centers for training" and belief that the churches should be places to train lay persons to be involved, active, and responsible in God's last-day ministry. She encouraged the uneducated to minister according to their abilities, and she supported training for preachers.

The Seventh-day Adventist church was just a couple decades old and her writing

\footnotetext{
${ }^{70}$ Turner, Proclaiming the Word, 24-26.

${ }^{71}$ A. J. F. Behrends, The Philosophy of Preaching (New York: Charles Scribner's Sons, 1890), 15.
} 
was significant in giving foundation to doctrinal identity, organizational structure, ministerial guidance and teaching authority and purpose of preaching.

White's first works had little to say about preaching, but focused on its spiritual aspects. Turner's research states that "Ellen White's concept of the function of the sermon largely focused on arousal, conviction and persuasion ... included the functions of instruction and teaching." ${ }^{.72}$ She was not originally the main preacher, it was her husband, James White. When James took ill and died Ellen White began to give her messages-she called them "discourses." It was after a regular schedule of preaching that she began to write much about preaching. She was troubled that "many do not look upon preaching as Christ's appointed means of instructing His people. ${ }^{, 73}$ But her beliefs and teachings are best summarized in her own words: "The preaching of the Word should appeal to the intellect and impart knowledge, but it comprises much more than this. The heart of the minister must reach the hearts of the hearers." ${ }^{, 74}$ She held formally trained clergy to high standards of preaching and also challenged both the ministers and laity to be well prepared to preach. While not wanting to discourage those men who had little or no education, she did censure those who were largely ineffective by stating: "The Christian ministry is no place for drones. There is a class of men attempting to preach who are slipshod, careless, and irreverent. They would better be tilling the soil than

\footnotetext{
${ }^{72}$ Turner, Proclaiming the Word, 44.

${ }^{73}$ Ellen G. White, Testimonies for the Church, 9 vols. (Mountain View, CA: Pacific Press, 1948), 5:300.

${ }^{74}$ Ellen G. White, The Voice in Speech and Song (Boise, ID: Pacific Press, 1988), 274.
} 
teaching the sacred truth of God..? ${ }^{75}$ However, she wrote many words of encouragement to uneducated men who were dedicated and teachable. ${ }^{76}$

Her writings continued to emphasize to ministers the importance of "last-day preaching" to include both the heart and the head. Ellen White further challenged church leaders to move beyond mere "practical training" toward embracing "advanced ministerial training. She often pushed for thorough advancement and highest standard of training of workers. ${ }^{77}$ Edward Turner's book, Proclaiming the Word, highlights four points of Ellen White' contribution to preaching for the future of the Church: "1) preaching is of primary importance to the life of the church. 2) Preaching and pastor care must function in interdependence. 3) The purpose of preaching is to announce the ... new life through faith in ... Jesus Christ. 4) The source of the preacher's message is the Word of God." 78

R. Edward Turner's thorough work on Ellen White's concept of preaching gives detailed chronology by dates. (Also documented is a chronological listing of non-Ellen G. White articles on preaching in the Review and Herald-the official written voice of the Advent Movement and church organization-1850-1905; most were written by Adventist pioneers, while some written by non-Adventist) ${ }^{79}$. What is notable is that few, if any, articles speak to the issue of "lay preaching" or contrast preaching by pastors as opposed to laymen. This trend gives way to reason that little is found on "lay preaching," during

\footnotetext{
${ }^{75}$ White, Testimonies for the Church, 5:582.

${ }^{76}$ Ibid 6:433.

${ }^{77}$ Ibid, 5:583, 584.

${ }^{78}$ Turner, Proclaiming the Word, 116, 17.
} 
this time of 'Revival in America' and early Adventism, because this time period and the persons addressing preaching did not differentiate between clergy and laity, between pastors and laymen. Laymen of this era were working men and women who also preached the gospel and routinely lead out in the work of ministry. Little is seen in the written work within the framework of Christians and Adventist during this time.

\section{Partnership of Clergy and Laity for Ministry}

Ellen G. White did address the importance of training the laity in broader ministry terms. She did write a significant amount about the involvement of laymen in the work of ministry: training laymen for "personal ministry"; equipping laymen for "medical ministry," "the health ministry," and "evangelism." Throughout her ministry she repeatedly admonishes the pastors (clergy) to embrace their responsibility to "put the members to work," "to find fields for the lay person to labor for the cause of God." following are statements that are found in many of her books and compilations on the work of the laymen.

White states with conviction that "the work of God in this earth can never be finished until men and women comprising our church membership rally to the work and unite their efforts with those of ministers and church officers." 81 When Ellen White wrote that "many would be willing to work if they were taught how to begin. They need

${ }^{79}$ Ibid., 149-178.

${ }^{80}$ White, Instruction for Effective Christian Service (1947), 15, 16.

${ }^{81}$ Ellen G. White, Gospel Workers: Instruction for All Who are "Laborers Together with God" (Washington, DC: Review and Herald, 1945), 332. 
to be instructed and encouraged," ${ }^{82}$ she was emphasizing her firm belief in the important Bible mandate on ministers to focus on training the laity. She pointed out the need of educating the laity and instructing them so they could do God's work. She further said: "It is the training, educating, that is needed. Those who labor in visiting the churches should give the brethren and sisters instruction in practical methods off doing missionary work." ${ }^{83}$ Many of these statements are restated, but essentially convey the same information and essence.

The cause of God in the earth today is in need of living representatives of Bible truth. The ordained ministers alone are not equal to the task of warning the great cities. God is calling not only upon ministers, but also upon physicians, nurses, colporteurs, Bible workers, and other consecrated laymen of varied talent who have acknowledge of the word of God and who know the power of His grace, to consider the needs of the unwarned cities. ${ }^{84}$

White emphasized the importance the collaboration of a ministry team of ministers and laymen of all professions. She knew the task was too big and was never meant just for the "ordained ministers." She also addresses the great need for ministry in our cities when she said: "and unless more is done than has been done for the cities of America, ministers and people will have a heavy account to settle with the One who has appointed to every man his work."-Letter 211, 1902, 7-10.(To Sands H. Lane, December 24, 1902).

It is of White's grasp of the enormity and urgency of the task of ministry-alerting the world to the eminent return of Christ - that she speaks repeatedly of a organized ministry work force. Referring to the NT model of lay training, she said "what can we

\footnotetext{
${ }^{82}$ Ellen G. White, Ministry of Healing (Mountain View, CA: Pacific Press, 1942), 150.

${ }^{83}$ Ibid.
} 
learn from Paul's training of Timothy and Titus.... This can be applied to laymen who hold positions of responsibility in local churches." ${ }^{~} 85$ Such a ministry strategy would set up "training schools" (not seminaries) to train lay persons to do the work of ministry by developing and enlisting their God-given "gifts of the spirit" for the work of God. These training school would teach, train and prepare lay persons for ministry "in all areas of labor . . . in all lines of work and ministry." ${ }^{, 86}$ Her writings are filled with references to "Christ method and example are to be employed to our field of laborers, ${ }^{, 87}$ referring to Jesus' method of teaching, training and mentoring his lay followers in all lines of ministry.

She wrote with the urgency of a fire alarm that "there is a world to hear the closing méssage of the great controversy... . He expects all, laymen as well as minster, to tell take the news to the world. ${ }^{, 88}$ So firm was her belief in training and preparing laymen for active service in the work of God that she counseled leaders that "at our gathering occasions (camp meeting) should as training schools. ${ }^{\text {,899 }}$ Also, she spoke to all believers when she wrote "All who are under the training of God need the quiet hour for . communion with their own God ... nurses, physicians, and laymen form the theme of

${ }^{84}$ Ellen G. White, The Acts of The Apostles (Washington, DC: Review and Herald, 1970), 158, 59.

${ }^{85}$ Ibid., $367,68$.

${ }^{86}$ Ellen G. White, Evangelism (Washington, DC: Review and Herald, 1946), 47.

${ }^{87}$ Ellen G. White, Instruction for Effective Christian Service (Washington; DC: Review and Herald, 1983), 28.

${ }^{88}$ Ellen G. White to Brethren and Sisters in Nashville and in Madison, 15 October 1906, Letter 318, 1906, Center for Adventist Research, Andrews University, Berrien Springs, MI.

${ }^{89}$ White, Instruction for Effective Christian Service (1983), 39. 
this book [Ministry of Healing]." consecrated laymen of varied talents, should join together for service. ... In every city there should be a city mission that would be a training center." $" 91$ These statements are consistent with her prophetic and profound statement in Great Controversy, (the chapter introduces its contents as a time of "religious awakening" that proclaimed the eminent return of Christ. Since the gospel would be preached with a loud voice to all inhabitants of the earth; speaking of the role of the laity in "the Great Religious Awakening" White wrote that "it was therefore largely committed to the humble laymen."

Both clergy (ministers) and laity (laymen, church members) have a role to play in the "end-time" ministry. White challenges ministers to find fields of service and train the laymen to do the work of ministry. She counsels laymen to be consecrated to the cause of God and use their God-given gifts for the work of ministry. She believed that the great commission of Jesus would not be carried out or completed without both ministers and laymen laboring together for the cause of Christ. An essential part of this collaboration is the teaching of laymen to share the ministry of the spoken word with the pastors.

\section{Summary}

This brief survey of Ellen G. White's concept of lay preaching has given the broad references he made to the importance of the laity in the "finishing of the work," which is consistent to her counsels on the involvement of laymen in all areas of ministry.

\footnotetext{
${ }^{90}$ White, Ministry of Healing, 17-19.

${ }^{91}$ Ellen G. White, A Call to Medical Evangelism and Health Education (Nashville, TN: Southern Publishing Association, 1954), 48.
} 
Turner, in summarizing White's contributions, said "Ellen White must be viewed as a major religious leader in the nineteenth-century American church. Her immense literary corpus, extensive public speaking and travelling, and essential leadership role within Seventh-day Adventism place her in a position of a major religious leader. ${ }^{93}$ Her personal experience of being an active lay person who took leading role in the development of the gospel ministry of the Advent Movement (later the Seventh-day Adventist Church; she was part of a era where the lay person was commonly immersed in ministry and revival movements.

Further, she believed in and counseled the Church to train the lay person and the ministers for effective service; to the point that she often spoke of the importance of establishing training schools in the cities, to teach, prepare and train "an army of workers" for ministry. Written monuments of her consistent teaching, counsels to church leaders and heart-felt passion, serve as a legacy to instruct and inspire laymen in the Body of Christ to service. One towering example is the book Christian Service, originally written as Instruction for Effective Christian Service (1925). ${ }^{94}$ It is a compilation of much of what Ellen White wrote on believers-"laymen"-being trained and enlisted in service. Subject areas she consistently spoke, wrote and taught are recorded under the following chapter headings: "The Call to Service," "Call to Young Persons," "Student to do Ministry Work," "The Church A Training Center," "The Cooperation of Ministers and Laymen," and "Miscellaneous Lines of Missionary Work."

\footnotetext{
${ }^{92}$ Ellen G. White, The Great Controversy Between Christ and Satan (Mountain View, CA: Pacific Press, 1911), 271.

${ }^{93}$ Turner, Proclaiming the Word, 126.
} 
Although Ellen G. White written works do not directly speak of "training lay persons to preach," they are saturated with pages and chapters addressing the importance of laymen to be trained in "all lines of service"-including preaching. Her personal journey and Christian growth attest to her involvement in "Christian Service". through her missionary activities, her testimony, her preaching, and her leadership in the Seventh-day Adventist Church. Throughout her life and ministry, she was a proponent of regular training of workers for the cause of God; the advanced training of clergy and laymen in all professions for the highest possible means of carrying the Gospel to the world. Based on her personal involvement in preaching as a lay person-for much of her life, her written works, her counsels to the Church and her passion for lay participation in all areas of ministry, it is a fair conclusion that Ellen G. White was a proponent of training lay persons to preach.

${ }^{94}$ White, Instruction for Effective Christian Service (1983). 


\section{CHAPTER FOUR}

\section{A MODEL TO TRAIN LAY PERSONS TO PREACH}

This chapter introduces and charts the course of a model program to train lay persons to preach. The model has two main areas: developmental and implementation. Developmental consist of: (1) foundations of development, (2) development in realministry setting, (3) application to real-time ministry-lay class setting. The implementation -three-step progression consist of: (1) development; (2) application; (3) on-going training to preach. This chapter shows the process of a working model as it unfolds in ministry.

\section{Developmental}

\section{Foundations of This Developed Model}

Genuine development is organic. Like a seed, it is planted and germinates and experiences stages of and growth toward maturity and highest point of productivity. Learning to proclaim the Word of God is much like the germination and growth of all living things. After all, the Word God is alive-a living entity-entering into the human organism, the preacher.

Three theological assumptions form the purpose and guide the plan and format of this project. First, ministry is the calling of both the clergy and the laity. All are called to ministry through the invitation to discipleship-all partnering with Jesus in His ministry of 
grace to mankind. Second, the Holy Spirit gave gifts to the church and the members of the church for the work of ministry. Both clergy and laity have been given gifts and a place in the work of God's church, His agency of reaching and saving souls. Third, pastors are called and train to and equip the body of Christ and its members, on how to use and develop their gifts.

These three assumptions are supported by four key areas. ${ }^{1}$ First, is the strength of Scripture: ${ }^{2}$ The Word of God charges the prophet, priest and king to "build up the body of Christ," calling us to "go make disciples", for the work of ministry. Second, is the foundational support of spiritual heritage. The church's tradition to train lay persons in many areas of ministry: church administration, witnessing, evangelism, community service, worship, leadership, etc. Third, is the strength of reason. Godly wisdom has directed the church over the centuries to do what makes good sense. Like any team that has back-ups players for each position, the preaching ministry needs back-up preachers"the bench"-to help them play the full game. Also, sports teams are constantly developing and training a younger group to learn and eventually partner, and then step-up to that position. Ministry can follow good reason also. Fourth, is the strength of experience. Years of ministry have taught us all that experience is a great teacher and foundation to all we do. My colleagues have struggled, learning from what does not

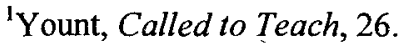

${ }^{2}$ Tbid.

${ }^{3}$ Ephesians 4:16 (All scriptures used are from the NIV unless otherwise noted).

${ }^{4}$ Matthew 28:19, 20.
} 
work and from what the situation and conditions call for. ${ }^{5}$ My personal experience as pastor has pointed to the need, highlighted and illustrated by weekly and yearly needs of churches to share the pulpit and have a balanced group of preachers declaring God's Word. 'Therefore, both theory and theology give foundation and support to the importance and mandate of training lay persons in the ministry of the word. Theology and theory do partner and to give solid support to the need to train lay preachers. Thus an intentional and effective plan can be activated, evaluated, and demonstrated as we grow ministry among both clergy and laity.

In preaching, the preacher develops as the Word of God is developed in her or him. The preacher grows in capacity to:(a) receive-accept, (b) believe-trust, (c) experience- live and (d) proclaim-share the Word. These are stages of growth. Therefore, those learning to preach must be prepared for these growth stages in preaching. The teachers and pastors facilitating also must recognize this and plan and organize the course so that students may experience the stages of growth in preaching. This model developed by making needed changes to fit the needs of its goal to most effectively train lay preachers. The courses and classes made necessary adjustments, as the instructors so fit, so it would development toward the best outcome. This model was planned and structured to facilitate students' full experience of each aspect of spiritual and practical preaching development. This Bible-based course is built on Jesus' model of training and making disciples. In addition, each lesson and preaching practice is spread over a one to two week period. God's salvation plan is comprehensive. Since the gospel touches the whole-person, likewise those proclaiming the gospel should

${ }^{5}$ Cline and Turner, Research Methods for Ministry Projects, 12-14. 
naturally speak to the whole-person. This model aimed to be a comprehensive training and development of the whole preacher.

This comprehensive model incorporates the preaching disciplines, and their connectedness (and interdependence). This kind of training model for the lay preacher develops preachers who will think "organically and preach organic sermons (holistic preaching that affects the whole person of the preacher and listener)." ${ }^{\prime 6}$ It incorporates these disciplines: spiritual, personal, theological and practical areas. The approach here is to develop well-rounded, balanced lay preachers who can minister to a very diverse world, affecting all areas of the life of those who "hear the Word." In this model the lay students also grow together in community, in a supportive environment where teacher and student, pastor and lay person develop jointly into God-grown ministers. Time and again, research has pointed to findings that have yielded results of the benefit of group learning. This evidence has been shown to apply in a wide range of subject and specialties where learning takes place. ${ }^{7}$ Human beings-children, youth and adults-seem to experience deeper and lasting learning when in a supportive group environment. ${ }^{8}$

\section{Development of the Training Model}

This model was designed and developed to meet the ministry needs of the field-

${ }^{6}$ Henry Grady Davis, Design for Preaching (Philadelphia, PA: Fortress Press, 1985), 139. There seems to be a direct parallel and connectedness of Davis' term, "organic," with the terms "developed" and "wholesome-" relating to and affecting the whole person, body, mind and soul. 20.

${ }^{7}$ Donald L. Griggs, The Planning Game (Livermore, CA: Griggs Educational Service, 1971), 12 -

${ }^{8}$ Thomas H. Troeger and H. Edward Everding Jr., So That All Might Know: Preaching That Engages the Whole Congregation (Nashville, TN: Abingdon Press, 2008), 92-94. 
local churches in the Chicago area. It was born out of the needs of pastors-to have capable and trained lay leaders ready to partner with them in the preaching ministry, and of lay persons who felt ill-equipped and unprepared to preach when called upon to minister the Word of God. As pastors and laymen realized their need, both were drawn to pray and plan a solution to this ministry problem. With much prayer and discussion this course was organized and planned for interested lay persons in the Chicago area to learn preaching.

Pastors were motivated by the current ministry need for a trained "army" of lay preachers who are hungry to be trained to preach. Pastors and lay persons in the Chicago area were inspired and challenged by these words Ellen White wrote almost a hundred years ago, "Many would be willing to work if they were taught how to begin. They need to be instructed and encouraged." A careful review of Jesus' model to training disciples and enlisting an army of laborers, gave the map to the ministry solution for training lay preachers in Chicago. White's writings, teeming with counsels to "give brethren and sisters instruction in practical methods of doing missionary work," 10 prompted pastors to take action. Discussions were fueled and plans were laid. Ideas and organizing turned into action. A preaching workshop was scheduled, the weeks and dates confirmed, flyers passes distributed in area churches. Bulleting announcements turned in, emails sent out, and a preaching workshop for lay persons was ready to begin. This was the first of its kind, birthed through collaboration of pastors and laymen.

\footnotetext{
${ }^{9}$ White, Gospel Workers, 332.

${ }^{10}$ White, Testimonies for the Church, 9:117.
} 


\section{Application of Real-Time Ministry/Lay Class Setting}

This model preaching course was developed with a long-term view to train lay persons to preach. It focused on selecting individual lay persons who have speaking talent and a passion for preaching.

This ministry project used observation, notes from class sessions, and surveys as means of evaluation. It made use of ministry skills such as listening, observing, analyzing documents, critical reflection, and class notes. This project recounted the "story" as it came to life in a real-life church-district setting, and evaluated using tools such as class attendance records, lesson plans, assignments and test scores.

This study involved lay persons from churches in the metropolitan Chicago, Illinois. Lay persons were given opportunity to sign-up for and register for an eight to ten session course in preaching. The class size was limited to twenty students, giving opportunity for maximum interaction between pastor/trainer and students. The students of this course filled out a registration sheet and a questionnaire to ascertain their opinion of preaching, their experience, and their need in preaching. The Participants were led through a practical, hands-on, experience in ten basic elements of preaching. They had homework assignments and class discussions. They had short student presentations and

each presented a short sermon, a full sermon, and a final exam. All students were graded by their peers and teacher. Each class began with a review of the last lesson and its assignments. Each class met Saturday afternoons for two hours during a time that facilitated maximum attendance and participation.

Each instructor (pastor) and student made regular use of preaching evaluation forms. Random church members were given "Post-sermon Evaluation" forms to indicate 
areas of strength and need for improvement. Both clergy and laity needed to learn that feedback is critical for growth and continued learning. The goal was also to keep lines of communication open between preacher and audience so that little was assumed, but much listening occurred in the life of the church.

\section{Implementation - Process of Progression}

Project Development

This project grew out of a ministry need for lay persons to help with the preaching ministry. The pastors needed preachers to help with their preaching schedules and laity felt the need to have more hands-on ministry involvement. Both from the clergy and laity, the need reached a "boiling point" that led to a coming together for a suitable solution.

The first Preaching Workshop was planned for four Saturday afternoons in April 2004. The growing interest in preaching led to more plans for another class; it developed into a ten-week series of classes-September to December 2004.

As pastor, I met with the church elders to assess their need, asked them questions and set up a game-plan to help them learn to preach. More ideas come from our dialogue and conversations during regular elder's meetings.

The following initial decisions and plans were made: (a) each elder's meeting would involve some training and tips on preparing sermons, (b) once a month church elders and other lay persons who were assigned to preach preached were called to meet for one-hour training session on preaching, (c) ideas developed into initial plans, and those plans later develop into more structured classes on preaching. They were designed for church elders and other lay persons asked to preach. 
This initial plan developed in a more structured course to train lay persons to preach. The course developed over time, from the first course to the second, and others followed. Each course brought about further development based on feedback, teamwork, and careful evaluation; with the long-term goal of preparing workers for work of ministry Jesus left to His Church. ${ }^{11}$

Development is essential to the progress and mindful of the process. ${ }^{12}$ It is foundational to a mindset that says: "we will live with an attitude and awareness of listening to God and each other to learn to better ourselves and sharpen our ministry skills for the most effective ministry." 13

This is the mindset of ministry that generated a model to train church elders to preach. It became this model course that grew and adapted to meet the needs of ministry in a metropolitan Chicago. This model course has the potential to expand its use to meet the need for training in North America and the world-wide Church.

\section{Project Application}

The project was applied to the lives and ministry of lay persons in the form of courses and class sessions. It involved (a) a selected team of instructors, (b) selected places suitable for instruction and learning, (c) suitable times for instructor and student, (d) elements for maximized learning: structure, boundaries, and related materials,

\footnotetext{
${ }^{11}$ Bernice McCarthy and Carol Keene, About Learning (Barrington, LL: Excell, 1996). About Learning, "The Learning Type Measure (LTM)," http://www.aboutlearning.com/products/assessments/ learning-type-measure (accessed September 23, 2009). This instrument is made available by About Learning Inc., 1251 N. Old Rand Road, Wauconda, Il 6008, 1-800-822-4628, or see aboutlearning.com.

${ }^{12}$ Ellen G. White, Christ's Object Lessons (Washington, DC: Review and Herald, 1941), 340-43.

${ }^{13}$ About Learning, "The Learning Type Measure (LTM)."
} 
(e) advertisement, application and the selection of participants, (f) course outline and class session content.

\section{Team of Instructors}

The instructors for the courses were a team of pastors who shared the same passion and saw the need to join together for the training of lay persons. Five pastors were involved in this project: Wayne Odle, Corale Odle, Ron Walker, Greg Robinzine, and Leeroy Coleman. We met with our lay leaders and listened to their need; compared notes from those meetings; prayed regularly for wisdom and guidance for the best direction to meet the ministry need.

\section{The First Year Preaching Model}

The first course was in April of 2004. The target area was Seventh-day Adventist Churches on the South-side of Chicago. Enrollment was open to anyone who signed up to take the course; 27 lay persons registered to start out the course. Classes were held for two hours-from $2 \mathrm{pm}$ to $4 \mathrm{pm}$ (in June the time was changed to $4 \mathrm{pm}-6 \mathrm{pm}$ )-the $2 \mathrm{nd}$ Saturday of each month from April to December. Classes rotated between four churches in the target area-of which enrolled students were members. The team of instructors each taught a part of the subject lesson each class. Students were given the requirements for completion and graduation from the course. To complete each course, participants were required to meet these minimum standards: $15 \%$-attendance, $15 \%$ graded 
1homework and class assignment, 10\% - quizzes, $15 \%-15$ minute sermon , $15 \%-30$ minute sermon, $30 \%$ - final exam. ${ }^{14}$

During the first course the teaching team was observant and ready to make adjustments and changes as needed. Following the first year's course, the teaching team compared notes, feedback and evaluations for planning the next course.

\section{The Second Year Preaching Model}

The second course was conducted in the Spring of 2005. Changes and adjustments were made to facilitate more balance in the schedule of all participants, encourage other lay persons to participate, and increase class participation for better learning. After a long stretch of 9 months for the first course, both instructors and students learned some important lessons, and made some practical observations. The following course adjustments were made: (1) the next course needed a shorter time frame -10 to 12 weeks; (2) class size was reduced to a maximum of 20 students; (3) classes were kept in the same location for continuity; (4) one instructor would do the lesson presentation, while others facilitate and led out in the class exercises.

The class time was kept at $4 \mathrm{pm}$ to $6 \mathrm{pm}$. Water and refreshments were provided to go hand-in-hand with class breaks. The second-year course was full: 20 students enrolled, and they were motivated and excited. Halfway through the course, facility problems led to a change in location and all participants adjusted well. Three students dropped out due to family and health challenges. A graduation ceremony was held for the 17 graduating students. Their family, pastors, church family and friends were invited.

\footnotetext{
${ }^{14}$ For Course Outline and Course Expectations, see appendix.
} 


\section{The Third Year Preaching Model}

The third year model developed based on observation, feedback, and experience from the second year. Plans were made for a series of four semester courses that covered a two-year-cycle. The courses would expose lay persons to each main area of preaching. Over a two years cycle the lay student would have a more comprehensive training in preaching. Each course would be four to ten weeks in length. This project was designed to stay with the students for a two-year period. The first year courses: (1) "Introduction to Preaching Workshop"-4 two-hour sessions during the Spring of the year; (2) "Introduction to Preaching Course-twelve weeks semester (Sept. to Dec.). Second year courses: (1) "Foundations for Preaching l"-twelve week semester (Mar. to May), (2) "Foundations for Preaching II"-12 week semester (Sept. to Dec.). 
Table 1. Two-year cycle model preaching course

\begin{tabular}{|c|l|c|}
\hline \multicolumn{3}{|c|}{ Two-Year Cycle Model Preaching Course } \\
\hline Yr & Spring Semester: 4 wk workshop & Fall Semester: 10 wk course \\
1 & "Introduction To Preaching I" & "Introduction to Preaching II" \\
\hline Yr & Spring Semester: 10 wk. course & "Fall Semester: 10 wk. course' \\
2 & "Foundations For Preaching I" & "Foundations For Preaching II \\
\hline
\end{tabular}

Class size was limited to 20 students to facilitate more class interaction, student participation, dynamic group learning and more opportunity for teacher-student time. Advertisement to area churches, pre-registration forms and timing were sent out two months in advance of the course. Course information was mailed out and communicated earlier, giving students more time to prepare to participate in this preaching course.

\section{The Fourth Year Preaching Model}

The fourth year preaching course continued the development process. Observations, notes and feedback from students and instructors led to the following adjustments: (1) smaller class size-from 20 to 15 , to give more instructor-to-student and student-to-student learning time; (2) the addition of recommendations from respective churches and pastors for registering students; (3) expanded plans for the graduation ceremony for students who completed the course: involving conference leaders, pastors, church members and family of graduates; (4) a coaching component was offered to students graduating from past and present preaching courses. Students interested in an on-going learning process in preaching could sign up for a more personalized 
coaching/mentoring session-a maximum of five students per pastor, for a six-month session.

Plans were made to use church facilities for the fourth year course. It would to provide for classroom and sanctuary to make the training site an on-site, hands-on, realministry setting for the lay preaching student. The first workshop rotated between churches, of which students were members, while later courses rotated to other regions (Chicago's north-side, south-side, east-side, west-side; suburbs: south suburbs, west suburbs, north suburbs). This rotation brought the preaching courses into many regions of metropolitan Chicago, providing for better accessibility to students in each region.

Preaching courses, with exception to the short 4-week "Introduction to Preaching I," were twelve-weeks in length. Courses included 8 to 10 lessons, weekly homework assignments, group projects, group interaction, class participation, class quizzes, a short15-minute-sermon, a long-30 minute-sermon, a 2-hour final exam, a course review and evaluation session, and a graduation ceremony.

\section{Class Session and Lesson Plans}

The lesson plans of this preaching model also experienced development over the four years. Adjustments and changes were made each year to give students the most helpful, concise and user-friendly lessons that would be usable after the course was completed. Later lessons were coordinated with the two-year cycle and each course concentration. Each class was a two-hour session, covering one to three lessons.

\section{Course Commentary and Notes}

The first course, the first year-April, 2004-was filled with anticipation and 
expectation. Twenty two students huddled in the computer room-fondly called the "upper room"-of Kenwood United Church of Christ (the facility Goshen SDA Church rented for its services). The first class started with a time of worship: for 15 minutes we worshipped in song, scripture and prayer. The history and reason for our gathering and class was given by Leeroy Coleman (pastor of Goshen SDA Church at that time). Time was allotted for all, instructors and students to introduce themselves. Students were given a Course Outline hand-out that gave a map of the course, place of meeting, time, lesson subjects. Wayne Odle (a pastor in the Illinois Conference) gave the course description and direction the course would take. Coleman and Odle were the main instructors for this first course. At each class session students were given a lesson outline; this enabled them to take note and actively listen and follow the lesson presentations by the instructors. In addition, Chaplain Ronald Walker and Pastor Greg Robinzine contributed by teaching a few lessons throughout the course.

Students were excited to be a part of the first of a kind of course offered in the Illinois Conference. They knew they were participating in something historic. This first class session, and the others that followed, carried an eagerness to learn and a chemistry of fellowship that is rare in class settings. Each student made great sacrifices of time and commitment to be part of this course. Thorough the course students were relaxed and open to participate by taking copious notes, asking questions and doing their best in the class exercises.

As the course progressed, some students found it difficult to meet for every class session. Student would call or email instructors (even in emergencies) to inform us that they could not make the session. Two months into the course, two students informed the 
instructors they could not continue due to health and/or family needs. They were kept informed, and class outlines and lessons were still emailed to them so they could keep a sense of connectedness to their fellow students and the course. The instructors felt it was more important for them to get all the information the course provided, even though they were not able to continue the course. When students missed a class they were able to get the class information and could make up their sessions on their own. There was a good spirit of cooperation in classes. Two other students felt "this was not for us." They were curious and expressed that they were not going to use this training since they did not have the gift of speaking or would be called to speak in churches. The class members expressed gratitude for them coming and validated their choice to not continue the course. Attendance was taken at each class session using a "class attendance sheet."15 Students attained an average of $95 \%$ attendance rate for the duration of the course. Class exercises were graded by peers during each class using a "class assignment grading sheet"16

The times of most anxiety, nervousness, and much fear were final sessions of the course: the short sermon, long sermon, and exam sessions. Instructors Coleman and Odle gave students examples of short and long sermons. Students were helped outside of class in sermon composition. Students also exhibited good spirit as they assisted and cheered each other on while sermons were preached. Long and short sermons were graded by

\footnotetext{
${ }^{15}$ Class Attendance Sheet sample can be found in the appendix. Students found them helpful to keep track of any classes missed and to make sure they caught up on all assignments

${ }^{16}$ Class Assignment Grading Sheet sample can be found in the appendix. Class grades were posted each session so students could be aware of how they were doing. They were posted by a student number, not name.
} 
fellow students and instructors, using "in-class sermon evaluation forms." ${ }^{17}$ Students also planned to meet outside of class to study and prepare for the final exam. Though anxious, they helped each other, called and e-mailed instructors for best ways to prepare. All students who took the final exam passed.

The first course was ground-breaking and exciting for both students and instructors. It could be done and it was done: a course to train lay persons was successfully completed. It took a full 9 months, starting with 27 students registered, 22 starting, and following a much extended time of training, 15 students completed the course and graduated. The graduation ceremony was planned by the instructor team. The goal of this ceremony was three-fold: (1) to celebrate the achievement of all who started the course, and those who completed it; (2) to highlight to the Christian community this new opportunity that is developing for the training of lay persons to preach; (3) to involve union and conference leaders for their awareness and further support as this vehicle of lay training developed.

The graduation ceremony of the first year lay preaching graduates was held at the Emmanuel S.D.A. Church, Chicago Heights, Illinois. Many friends, family members, lay leaders and conference representatives attended. The church was filled with 127 in attendance. Graduates lined up and marched in with other platform guests: Ken Denslow -Illinois Conference President, Guest Speaker-Andrews University Seminarian Fred Nichols. The fifteen graduates, fellow class mates, and the church community were given a greater awareness of God's call to lay preachers and their role in the ministry of

\footnotetext{
${ }^{17}$ In-Class Sermon Evaluation Forms can be found in the appendix. Each sermon was evaluated by the student's peers and the class instructors.
} 
the church to fulfill the commission of Christ. Five lay persons expressed their interest in future lay preaching classes.

Graduation ceremonies of the preaching courses the following three years had similar plans and dynamics. The graduations ceremonies of years 2 to 4 were planned with more input from students and graduates of those respective classes. But each had its own unique dynamics and unique surprises that kept both students and attendees in anticipation of an inspiring and productive time where lay ministry was promoted and celebrated.

Table 2. Lay preaching program trends

\begin{tabular}{lccc}
\hline COURSE -YEAR & Students registered & Students enrolled & Students graduated \\
\hline 2004 (9 months) & 27 & 22 & 17 \\
2005 (12 weeks) & 20 & 15 & 12 \\
2006 (12 weeks) & 14 & 12 & 10 \\
2007 (12 weeks) & 10 & 10 & 7 \\
2007 (6 months) & 5 & 54 & 5 \\
\hline Total & & 51 & \\
\hline
\end{tabular}

Source: Class Records (since there were only two preaching instructors, each year there was a lower number accepted to reduce class size so that teacher-student ration would allow for more student/teacher interaction ['04 class size not limited; '05 class limited to 20; '06 class limited to 15; '07 class limited to 10]). 


\section{Session Plan and Lesson Subjects/Titles}

Following is a list of the titles and subjects of the class sessions offered that correspond to each of the four main courses covered in the two-year preaching cycle of this model. The class sessions were modified into three sections: (1) lesson presentation35 minutes, (2) student/group interaction-35 minutes, (3) student presentations-35 minutes (this included a 5 minute break between each section). ${ }^{18}$

\section{Course I: "Introduction to Preaching I" (4 week session)}

Session 1 "Preaching: God's Plan for Proclamation"

Session 2 "Preacher: Knowing God, Word and World"

Session 3 "The Messenger: Man, Message and Masses"

Session 4 "The Methods: Purpose, Plans and People"

Session $5 \quad$ 15-Min Sermon, Test Class, Course Evaluation

\section{Course II "Introductions to Preaching II" - 12 week course}

One or more lessons/subjects were taught each session:

Session 1 "Spiritual Foundation and Preparation"

"Sermon Types and Emphases"

Session 2: "Gathering Material I"

"Sermon Titles"

"Putting It All Together"

Session 3 "Sermon Resources"

${ }^{18}$ See appendix for "Class Outline" and "Lesson Outlines." Students were given a course and class outline at the beginning of each course. Each class had handouts of the specific class subject to be covered. Students were also given handouts with assignments to be completed between class sessions, and for the upcoming class. 
"Sermon Outlines"

Session 4 "Sermon Illustrations"

"Painting Pictures

Session 5 "Narrative Preaching"

Session 6 " "Gathering Materials II"

Session 7 "Sermon Applications"

"Sermon Appeals"

Session 8 "Heading For the Cross"

Session 9 "Injecting Spirituality"

Session 10 "Short Sermon"-15 minutes

Session 11 "Long Sermon"-30 minutes

Session 12 Final Exam-2 hours allotted time

\section{Course III "Foundations of Preaching I"-12 session}

Session 1 "The Call to Preach"

"Gift of the Spirit: Preaching".

Session 2 "The Role of the Lay Preacher"

"The Spirit and the Lay Preacher".

Session 3 "Preaching Partner with the Pastor"

"Shepherd Preaching: Teaching the Flock"

"Shepherd Preaching: Training the Flock"

Session 4 "Finding the Preaching Passage"

"Personal Devotion and Preaching"

"Personal Spiritual Journey and Preaching" 
Session 5 "Exegesis - Biblical Mining of the Text"

Session 6 "Exegesis to Exposition: Sermon Process".

Session 7 "Sermon Strategy: Message Outline

"Sermon Strategy: Writing for the Listener"

Session 8 "Strategies for Sermon Preparation"

"Preparation is $90 \%$ of Your Work"

"The Right Tool for the Right Job"

Session 9 "Mailman: Delivering the Message"

"Delivery: Deliberate Designs"

"Delivery: Matching the Style with Message"

Session 10 "Short Sermon"-15 minutes

Session 11 "Long Sermon"-30 minutes

Session 12 Final Exam-1.5 hours allotted time

\section{Course IV "Foundations of Preaching II"-12 weeks}

There were Group-class sessions. Class met the first week each month. Other sessions are student preaching labs in public worship settings.

Group Session 1-Week 1

"The Master's Methods: Jesus' Preaching Model"

Group Session 2-Week 4

"Sources and Results of Spirituality: Sermon Chest"

"Searching the Source: Studying for Preaching".

Group Session 3-Week 7

"Meaning: Observation, Interpretation, Application" 
Group Session 4-Week 10

"Audience Adaptation: Connecting with Listeners"

Group Session 5-Week 12

"Preaching Conference: Sermons and Graduation"

\section{Class Session}

Each class session was designed to give students a variety of learning experiences: listening, group interaction, self-study time, and class participation. The sessions followed this order: (1) students participated in assigned homework from previous session with answers and discussion, (2) instructors presented lessons, (3) students participated in lesson exercises, (4) homework assignments for next session passed out and clarified.

\section{On-Going Training for Lay Preachers}

This practice in ministry will also propose a model for pastors to mentor-provide on-going training-their church elders and lay preachers. This will be done by showing how pastors can prioritize by making themselves available for on-going training. This can be done in these ways and settings: at elder's meeting, monthly preaching-group focus groups, setting up preaching teams and preaching support groups, and also, giving time to do one-on-one coaching to each of the lay preachers in their congregation/s. Each pastor and lay preacher will make notes of each meeting, focus group, and session. They will write out goals for preaching and indicate areas needing attention and work; also areas of strength and interest for preaching. Pastors and students then adapt a mind-set of lifelong learning, growth in preaching, and the training others to preach. 
The on-going training of lay preachers focuses on five elements: (1) "The coaching component"-how it connects to the developed model to train lay persons to preach, (2) principles of mentoring, (3) practical principles of educating adults, (4) the account of the how coaching component worked with one pastor and five elders, (5) practical considerations for "coaching" lay persons.

\section{The Coaching Component}

The coaching component is the practice of mentoring others and applying the principles in your area of training and/or expertise. The emphasis is on coaching. Coaches of sports teams know the game they coach well. They are able to observe and analyze the game, the players and give their team the best strategies and approach to win. They also are able to give objective feedback to their peers. Coaching involves giving your players the proper training, regular practice and honest feedback to maximize their development and performance in that sport. It can lead to similar results when training lay preachers with a preaching coach; the same principles and practices apply.

The difference with the "coaching component" is that more personal training is involved-mentoring. This approach works with a small group of lay persons: one to five. The pastor can work with one individual this week and another the next week. The small group may meet once a month to have a joint session and compare notes. The essence of this plan is for each lay person to have one-on-one sessions with the "coach" to get assistance and ideas in planning a sermon or talking through how a previously preached sermon went. It is a time of mentoring, not just an event.

The coaching component is important to this developed model for these reasons: (1) after the preaching courses, each lay preacher will need the interaction, input and 
leadership of their pastor. This will give them opportunity to preach and attend on-going events to facilitate a growth in their preaching; (2) the lay preacher needs feedback from one who preaches regularly; (3) the pastor and local church are significant contributors for continued preaching development.

This project included a "coaching component" in the model. Pastors (or other trained ministerial leaders) would serve as coaches, instructors who would carry out the on-going learning process for lay preachers. The "coaching component" also involved helping pastors to be best prepared to teach and train lay persons in the ministry area of preaching (the principles and practices of this component may be applied to other ministry areas). The Bible mandate for pastors is for them to be shepherds (Ezek 34), teachers (Eph 4:10-12), trainers/equippers (Eph 4) of the body of Christ. Pastors would be further equipped by a seminar or training sessions that would equip them on how they can apply, incorporate and implement the "coaching component" into their ministry of training members.

\section{The Mentoring Principle}

As it is in sports, so it is in preaching. Developing preachers need other preachers they look up to and admire to challenge and motivate them to achieve their best. The Apostle Paul intentionally mentored Timothy in ministry (I Tim 1:1, 18; 2 Tim 3:10-17; 4:2). Continued training of lay preachers can involve the pastor being that mentor, or facilitating the connection of his lay preacher to a preacher they admire. Many lay persons have expressed their desire to have, not an idol preacher, but one who is downto-earth, with whom they can regularly interact. . That pastor-coach will be there on a consistent basis to show them the rope and release them to grow as a preacher. 
Every pastor may not be a great preacher, but their lay preachers can learn much from their style, preparation routine, preaching practices, delivery and many other aspects of their preaching. Each pastor can play a significant role in coaching their elders in the ministry of preaching.

\section{Principles of Adult Education}

As pastors and ministry leaders train lay persons to preach, it is crucial for them to know their students well. Their students will be adults. They will be educating and training adults. Many pastors are not trained or versed in the principles of education, much less adult education. John Dettoni stresses the importance of educators knowing their students so they can effectively teach for maximum understanding of their students. ${ }^{19}$ It is important that pastors know and learn how to apply the basic principles and practices that will enhance their training and teaching of the adults in their classes and seminars. Here are some important principles to understand and practical steps to implement that will make their preaching classes effective.

\section{In Touch With Needs and Requirements}

Education specialists and experts have discovered and developed pertinent principles and practical advice for those involved in educating adults in just about any field of study. Being an effective adult instructor requires the teacher to be versed in the special needs and requirements of adult learners. Malcolm Knowles, a pioneer in adult learning, has identifies six essential characteristics of adult learners: (1) they are

\footnotetext{
${ }^{19}$ John M. Dettoni, "Psychology of Adulthood," in The Christian Educator's Handbook on Adult Education, ed. Kenneth O. Gangel and James C. Wilhoit (Wheaton, IL: Victor Books, 1993), 77-87.
} 
autonomous and self-directed, (2) they have an accumulated foundation of life experiences and knowledge, (3) they are goal-oriented, (4) they are relevancy-oriented, (5) they are practical, (6) they expect be taught with respect. ${ }^{20}$ Those who instruct adults to preach will need to incorporate these characteristics into the planning, approach and lesson plans for their students. ${ }^{21}$

The following chart is a summary of the distinctive features of four ways adults know. These four types of adults know differently: they have primary ways they learn, listen, socialize, and interact. Knowing these types of adult learners can help the adult teacher to be more effective and maximize the opportunities for all their adult students they encounter.

${ }^{20}$ Malcolm S. Knowles, The Modern Practice of Adult Education: Andragogy Versus Pedagogy (Chicago, IL: Association Press/Follett, 1970). Knowles first work, Informal Adult Education (New York: Association Press, 1950), was his original edition from His Master's Thesis. As pioneering scholar and practitioner in the field of adult education, numerous articles and books abound about his theories and groundbreaking work.

${ }^{21} \mathrm{~A}$ wealth pertinent and practical information is available under the subject heading of "Adult Education." Andragogy offers books, articles and instructional guides can be found to assist the beginner to the expert in this area of educating adults. Simple and practical helps are available that can be incorporated into the lessons and classes for adults. 
Table 3. Summary chart for different adult ways of knowing

\begin{tabular}{|c|c|}
\hline AFFLIATING AL & BARGAINING BETTY \\
\hline $\begin{array}{l}\text { Interpersonal } \\
\text { Non analytical } \\
\text { Feelings } \\
\text { Absolutes } \\
\text { Symbol \& reality inseparably bound } \\
\text { Symbols have one true meaning } \\
\text { Feelings bound with symbol } \\
\text { God as personal } \\
\text { Affectional groups } \\
\text { Persons loved and good } \\
\text { Law prevents chaos } \\
\text { Justice: good intentions } \\
\text { Bible: true meanings }\end{array}$ & $\begin{array}{l}\text { Interpersonal relationships } \\
\text { Analysis not separated from feelings } \\
\text { Feelings } \\
\text { Whatever anyone feels true } \\
\text { Tolerance of others who are not coercive } \\
\text { Symbols have multiple meanings } \\
\text { Symbols \& reality inseparably bound } \\
\text { Preferences bound with symbol } \\
\text { God with personal qualities } \\
\text { Multiple affectional groups } \\
\text { Persons are more important } \\
\text { Law protects preferences } \\
\text { Justice: good intentions, not good coercive } \\
\text { Bible: Different meanings each person }\end{array}$ \\
\hline CONCEPTUALIZING CHARLES & DIALECTICAL DONNA \\
\hline $\begin{array}{l}\text { Centered on rational systems } \\
\text { Consistency \& coherence } \\
\text { Valid versus true } \\
\text { Symbol separated from conceptual reality. } \\
\text { Rational bonding to symbol's concept } \\
\text { God concepts: justice, power } \\
\text { Social \& institutional structures } \\
\text { Persons contribute to systems } \\
\text { Law structures and maintain social } \\
\text { systems } \\
\text { Justice: maintain social systems } \\
\text { Bible: abstract concepts and meaning }\end{array}$ & $\begin{array}{l}\text { Pluralistic \& ambiguous } \\
\text { Dialectical/paradoxical } \\
\text { Integration \& commitment } \\
\text { Symbol participates in reality } \\
\text { Emotional/rational bonding to new vision } \\
\text { God in all God's complexity } \\
\text { Open and inclusive society } \\
\text { Intrinsic value of persons } \\
\text { Law preserves basic rights } \\
\text { Justice: universal principles; legal/moral } \\
\text { Bible: dialogue partner with others }\end{array}$ \\
\hline
\end{tabular}

Source: Adapted from Thomas H. Troeger and H. Edward Everding Jr., So That All Might Know: Preaching That Engages the Whole Congregation (Nashville, TN:

Abingdon Press, 2008), 90-109. 
Table 4. A comparison of pedagogy and andragogy

\begin{tabular}{|l|l|}
\hline $\begin{array}{l}\text { Children are dependent on } \\
\text { parents/teachers }\end{array}$ & Adults are independent and self-directed \\
\hline Children have very little experience & Adults have a wealth of experience \\
\hline $\begin{array}{l}\text { Children's readiness to learn is dependent } \\
\text { on biological, social and mental } \\
\text { development }\end{array}$ & $\begin{array}{l}\text { Adult readiness to learn is determined by } \\
\text { social roles or task brought by life } \\
\text { situations }\end{array}$ \\
\hline Children learn things to be used in future & $\begin{array}{l}\text { Adults learn what they can use and apply } \\
\text { now }\end{array}$ \\
\hline $\begin{array}{l}\text { Children function well under authority, in } \\
\text { formal and competitive environment }\end{array}$ & $\begin{array}{l}\text { Adults function best in a climate of } \\
\text { mutuality, respect and collaboration }\end{array}$ \\
\hline Pedagogy is subject centered & Andragogy is problem centered \\
\hline The teacher alone does the planning & Learners participate in the planning \\
\hline The teacher diagnoses children's needs & Learners participate in diagnosis of needs \\
\hline The teacher formulates objectives & Learners participate in objective planning \\
\hline Memorization is important & Understanding and applying is important \\
\hline Learning is by listening & Learning is by doing and applying \\
\hline The teacher evaluates the learning & Learners assist in evaluation of learning \\
\hline Learning is compulsory & Learning is voluntary and desires \\
\hline
\end{tabular}

Source: Nancy Vyhmeister, Class outline for CHMN 610: Teaching Ministry, Andrews University, Berrien Springs, MI, 1992, 14-16.

\section{Guided Instruction for Present and Future Competency}

Knowles also left important words and principles for instructors of adult education to put into practice when he said: "Teaching is a process of guided interaction between the teacher, the student, and the materials of instruction... Teaching, like medical practice, is mostly a cooperation with nature. The function of the teacher is to guide the student into the kind of experiences that will enable him (sic) to develop his own natural potentialities. ${ }^{22}$ This statement challenges pastors and church leaders, who have been entrusted with the growth and training of believers in the body of Christ, to

\footnotetext{
${ }^{22}$ Knowles, The Modern Practice of Adult Education, 113-115.
} 
make plans and set goals, enlist and engage lay persons for the preaching task of ministry.

Knowles' believed that adult education was not an option, but a necessity for America. In a infamous statement he insisted that "the greatest danger to the survival of civilization today is not atomic warfare, not environmental pollution, not the depletion of natural resources ... but the underlying cause of all of them-the accelerating obsolescence of man.... The only hope now seems to be a crash program to retool the present generation of adults with the competencies required to function adequately in a condition of perpetual change." 23

\section{Motivators and Motivation Principles}

In addition to his six characteristics, Knowles purports that those who teach adults must also understand and apply the principles of adult motivation. Stephen Leib, a senior technical writer and planner, observed that the adult learner is fueled by six motivators: social relationships, external expectations, social welfare, personal advancement, escape/stimulation, and cognitive interest. ${ }^{24}$ Since adults have many responsibilities to juggle while being a student, it is crucial for those giving them instruction to plan for and work to eliminate barriers to learning.

Barriers to adult learning are very real, and can be multiplies and interwoven in a church/religious setting. They can include lack of time, confidence, interest, money, scheduling problems, lack of information about learning opportunities, availability of

\footnotetext{
${ }^{23}$ Knowles, The Modern Practice of Adult Education, 116-122.

${ }^{24}$ Stephen Lieb, "Principles of Adult Learning," VISION (Fall 1991): 117-132.
} 
child care, and more. Adult motivators are very real and substantial: requirement for competency, promotional prerequisites and opportunities, maintaining skills, adapting to job changes, complying with company directives. ${ }^{25}$ Therefore, pastors and instructors must find ways to enhance the reasons for lay persons to enroll in classes and diminish barriers. There needs to be intentional awareness as to why lay persons enroll, factors keeping them from further learning, and careful plans and strategies to foster continued learning and growth. Edwin Linberg, in his dissertation concludes that "it is the enabler, not the teller, the doer, the coercer, or the admonisher, who will ultimately be instrumental in helping God's people to overcome the gap between the visions of a renewed Church and the actuality of a renewed Church." ${ }^{26}$ The successful pastor and ministry will be one who is ever conscious and involved in training lay persons by showing them the relationship between on-going training and on-going ministry effectiveness.

\section{Effective Adult Instructors Use Effective Elements}

Author and instructor, Stephen Lieb-an adult specialist for the state of Arizona, has developed his "Learning Tips for Effective Instructors." He lists the following elements which can ensure that adults learn: motivation, reinforcement, retention and transference. ${ }^{27}$

${ }^{25}$ Lieb, "Principles of Adult Learning," 117-132.

${ }^{26}$ Edwin C. Linberg, "An Examination of the Role of the Clergy as an Enabler of the Development and Growth of the Ministry of the Laity" (D.Min. thesis, Claremont School of Theology, 1975).

${ }^{27}$ Lieb, "Principles of Adult Learning." 
Pastors and instructors can motivate lay preachers by (1)setting a positive feeling and tone for each class and lesson: a friendly and open atmosphere assures the lay preacher that you will help them, (2) set the level of concern to match the level of importance of lesson, (3) set appropriate level of difficulty-challenge, predict and reward participants. ${ }^{28}$. Lay preachers need specific results of their learning emphasized and their progress highlighted. They need specified feedback and concrete rewards. Their interest is connected to their reward.

Instructors of adult students need to be able to use positive reinforcement and negative reinforcement. Both carefully applied help to change behavior and maximize success. ${ }^{29}$ Many educators are realizing the importance of the two sides of the adult education coin: instructor-guided interaction and student-managed initiative. Pastors and ministry leaders are given responsibility to provide the opportunity for continued instruction and training for lay persons in the ministry. To effectively maximize learning opportunities, the principles and practices of adult education should be incorporated into the training of lay preachers.

\section{Application of Coaching Practice in Ministry}

An important phase of this model to train lay preachers was a session to coach selected preaching students. This coaching phase involved three elements: (1) one-to-one

\footnotetext{
${ }^{28}$ James Fisher and Ronald Podeschi, "From Lindeman to Knowles: A Change in Vision," International Journal of Lifelong Education 8, no. 4 (October-December 1989): 345-53.

${ }^{29}$ Joseph Davenport and Judith Davenport, "Andragogy: Another Bandwagon or Legitimate Tool in the Continuing Education Armamentarium?" Paper presented at the Annual Conference of the National Association of Continuing Education Directors. (Washington, DC, October 1984).
} 
mentoring of pastor with five lay persons, (2) organization of student groups and preaching partners, (3) semi-annual workshop-gatherings of student preachers.

\section{One-on-One-Mentoring}

The pastor/instructor coached five elders who participated in a preaching course. He met with them for six months to have individual mentoring sessions. During the six month mentoring sessions each student prepared one sermon each month with the personal coaching of the pastor. The lay person shadowed the pastor in the complete sermon preparation process-from preparation to evaluation. Each elder had access to the pastor for help in preparation of each message. They e-mailed, faxed or showed hard copy of message at each stage of preparation for their coach's feedback and direction. Sermons were given a final review by the coach before being preached. There was an immediate evaluation after sermons were preached, a review of audio or video recording of their sermon. Five random members were selected to evaluate the message using the post-sermon survey. ${ }^{30}$

Church elders also evaluated the "coaching component." Each elder evaluated based on their participation and experience, the opportunity to learn from and dialogue with their pastor/coach; their progress and improvement in preaching were charted, and a final review of the six-month coaching component session.

\section{Student Groups and Preaching Partners}

Lay preachers who were selected to participate in the coaching component were

\footnotetext{
${ }^{30}$ The Audience Post-sermon Survey can be found in the appendix of this dissertation.
} 
given opportunities to wörk together as a team on selected scriptures and subjects.

Students were assigned to collaborate and explore many ways to approach a bible text and subject. They were encouraged to think critically, theologically and practically as to approach the "preaching portion." Assigned group activities and exercises like these give lay preachers experience in working as a team on their sermons. On-going contact and team work at the end of the course was designed to instill unselfish support of other preachers. The elders expressed much appreciation for this exercise and activity. (These five elders, as well as the many other lay persons who enrolled in the preaching courses, shared phone numbers and e-mail addresses so they could continue the "fellowship of preachers" and bond that developed among them during the course). One Student said, "this gave me a new look at and appreciation of preachers."

Elders were also assigned to work in two's to prepare to team-preach a message. This was exercise to teach them the key elements of sermon preparation, to see and communicate each aspect of the message concretely and spiritually. Each pair of elders team-preached a short message. They evaluated their sermon, their peer's segment and had a review session with their preaching coach. They found this preaching activity difficult and challenging, but they expressed how much it stretched their focus and disciplined them for the hard work of preaching.

\section{Semi-Annual Preaching Workshop-Gatherings}

Another element of the coaching component was a gathering of preaching students. Students from any past preaching course were invited. The purpose was to: (1) provide a forum for continued dialogue, (2) encourage long-term contact and fellowship, (3) encourage lay preachers to keep growing and sharing preaching ideas, (4) allow 
instructors to demonstrate their availability and desire to remain teachers and mentors to lay persons, (5) help stir other pastors to give consideration to the role they too can play in training lay persons to preach.

These twice-a-year workshop gatherings were well received and well attended. They were advertised first to past and current lay students of this preaching course. Each student could invite one other lay person to attend. Two students were selected by the instructors to give a sample, short devotional message. A preaching guest was invited to be presenter for the workshop. Lay persons had time for questions and to participate in preaching exercises. It was a time to enjoy the camaraderie of preachers and be challenged to grow in the ministry of preaching. The lay preachers expressed that they now felt accepted, honored, and valued as essential to the ministry of preaching. "We are on the team!"

In all, each aspect of the "coaching component"-the one-on-one mentoring, the group and partnership activities, and the semi-annual workshop-gatherings-was designed to instill desire among lay persons for continued learning and growth in preaching. As pastors and professional preachers have to take continuing education and continue to work at the craft of preaching, even so do lay preachers need to embrace an attitude to continue their preaching education. In addition, preachers can easily feel isolated and alone. So it is important to demonstrate to lay preachers the value of connectedness and fellowship of preachers.

\section{Seven-Step Process}

A possible structured approach (using Knowles 'technology' of learning) in the 
development of this model's "coaching component," is a seven step process. Instructors of Adult lay preachers will need to:

1. setup a cooperative learning climate

2. create mechanisms for mutual planning

3. listen to the learner needs and interests

4. formulate learning objectives based on the needs and interests

5. design training activities for achieving the objectives

6. execute the design by selecting methods, materials, and resources

7. evaluate the quality of the learning experience while reassessing needs for further learning. ${ }^{31}$

Applying this coaching component to real-time ministry can be a means of helping pastors to train their elders and lay preachers. This model is an example of what can be done, but not limited to the need or to be done in the same way. The biblical principles outlined are more crucial now: pastors are called to train our laity for ministry; lay persons in North America are an untapped workforce. The laity form a preaching team to share the preaching responsibility (as with other areas of ministry); lay persons are willing and waiting to be trained; each pastor can start where they are-with a small group of elders and lay persons, giving classes a few times each year and building up to a seminar, workshop and regular classes. Luke records Jesus' words: "He told them, 'The harvest is plentiful, but the workers are few. Ask the Lord of the harvest, therefore, to

\footnotetext{
${ }^{31}$ Robert Carlson, "Malcolm Knowles: Apostle of Andragogy," Vita Scholasticae 8, no. 1 (Spring 1989). In this article, Carlson outlines and summarizes Knowles "technology" of adult learning. This article highlights the strengths of Knowles theory and practice of educating adults, amid a traditional field of education in which adult learning was very much an unexplored field of study and practice.
} 
send out workers into his harvest field"' (Luke 10:2). Pastors training lay persons to preach, is a Bible-mandated and God-ordained method of building up God's work force for the harvesting of souls. 


\section{CHAPTER FIVE}

\section{EVALUATION OF THE PROJECT}

This project, A Model to Train Lay Persons to Preach, included a variety of evaluation instruments. These instruments were to give students, audience, and course instructors opportunities to evaluate the course. The evaluation process was geared to give place for feedback from different groups to get the widest range of eyes to evaluate this project. Evaluations came from individual students, from focus-group of lay students, from church members of who heard their fellow lay person preach, from other pastors, and from the instructors of the courses. Evaluation instruments included: precourse survey of lay persons preaching experience, audience sermon feedback form, coaching session evaluation form, course evaluation form and instructor evaluation form.

\section{Students Evaluate the Course}

Students were the primary source for the evaluation of this project. The project is for their need and growth in preaching. The lay students received a variety evaluation instruments: pre-course survey, course evaluation, coaching evaluation, a focus group evaluation, and instructor evaluation.

Each instrument evaluation was tabulated; tabulation scores were recorded and reviewed. Selected church members evaluated the lay preachers' progress, and pastors 
who were involved in teaching the course used the evaluation surveyed. ${ }^{1}$

\section{Survey of Lay Persons' Preaching Experience}

This survey was given at the start of the course.

Results: 28 lay persons evaluated the 1 st course.

1. 7 were never asked to preach, 19 preached 2 to 4

2. 6 felt completely unprepared to preach, 9 felt very little prepared, 13 felt somewhat prepared, 0 felt well prepared

3. $11 \mathrm{had}$ no training in any form, 9 had training for elders, 6 had preaching workshop, 0 had class in public speaking, 0 had class in preaching, 0 marked "other"

4. 2 said books to read, 7 time with experienced pastors, 9 personal mentoring with a preacher, 8 specific preaching classes, 0 marked "other"

5. 15 said their pastor has been a visible model and example, 3 pastors listened and critiqued their sermon, 21 pastors gives opportunity to preach, 0 pastors teach and expose them to preachers, 7 pastors played no role, 0 marked "other"

6. 2 said conference gave information and resource, 0 provided workshops and classes, 0 conference helped their pastor train and mentor, 0 conference paid for them to attend seminar, 25 conference played no role, 0 marked "other"

\footnotetext{
${ }^{\mathrm{l}}$ Surveys and evaluation forms are listed in the appendix of this dissertation by name.
} 
7. 6 to expose to more resources and information, 19 to learn the basics, 11 to grow in my ability, 0 to preach regularly, 0 to preach evangelistic series, 0 marked "other"

The survey results indicate: (a) few lay persons had ever had significant training to preach, (b) lay persons have received little or no training in preaching by conferences, churches, and pastors, (c) most lay persons feel unprepared to preach, (d) lay persons have a high desire to be taught and trained, (e) lay persons want their pastors involved in helping them learn to preach.

\section{Course Evaluation}

Results: 23 participated in this evaluation.

Section I: Rate answers 1-low, 5-high.

1. Question: The course was long overdue. 19 respondents marked 5 (highest), 4 marked 4.

2. Question: I needed this course. 20 marked 5, 3 marked 4.

3. Question: Lessons were specific and helpful. 17 marked 5, 6 marked 4.

4. Question: Contents and format were beneficial. 21 marked 5, 2 marked 4.

5. Question: The course was difficult. 11 marked 5, 9 marked 4, 3 marked 3.

6. Question: The instructors taught the classes well. 18 marked 5, 4 marked 4, 1 marked 3.

7. Questions: The course was biblical and practical. 20 marked 5, 3 marked 4 .

8. Question: The class times were agreed upon and good. 17 marked 5, 3 marked 4, 3 marked 3. 
9. Question: The course length was good. 7 marked 5, 5 marked 4, 9 marked 3,2 marked 2.

10. Question: Class activities enhanced learning. 17 marked 5, 6 marked 4.

11. Question: Class participants learned together as a team. 9 marked 5, 11 marked 4, 3 marked 3.

12. Question: I would recommend this course to lay persons. 19 marked 5, 4 marked 5.

Section II: True or False, "T" for true, "F" for false.

1. Question: I have not heard of a course like this before. 20 True, 3 False

2. Question: This is my first course in preaching. 22 True, 1 False

3. I believe every elder should take this course. 21 True, 2 False

4. Question: This course can benefit each church and pastor. 23 True, 0 False

5. Question: I would take this course again. 22 True, 1 False

6. Question: I need to learn even more about preaching. 23 True, 0 False

7. Question: There should be a follow-up course to this one. 23 True, 0 False

8. Question: Preaching is an important lay persons' ministry. 23 True, 0 False

9. Question: I am realizing preaching requires much work. 23 True, 0 False

Section III: Written thoughts shared (sample of 5).

"I thoroughly benefited from and enjoyed each class. The course offered so much that I need to take it again."

"I look forward to the follow-up preaching course."

"A shorter course would be practical for my schedule." 
"I am glad all this information was not squeezed into one weekend. Each week gave me time to digest and practice the principles of preaching taught; there is so much to learn."

"Excellent teaching, material and teachers.... Our instructors took the time to help each one of us learn how to preach."

Audience Evaluation of Lay Sermon: Post-Sermon Survey

The result and rates of audience evaluation gave substantial indication that the lay preachers/elders made significant improvement in their preaching. The scores indicated lay preachers improved in all the elements of the sermon:

Results: 10 randomly selected church members evaluated each lay persons who participated in one of the preaching courses. A total of 50 members evaluated lay sermons.

1. Highest areas of improvement: 40 out 50 members rated "Sermon quality," "use of the Bible," "captured attention," "Clarity," and "relevance of the message" a 4 on the scale (1-low, 5-high).

2. Next highest scores were for "subject covered"' and "effective appeal." 10 out of 50 members rated these a 3.

3. The "relevance and helpfulness" was rated 3 by seven members, a 4 by 34 members, and a 5 by 9 members.

4. 47 of the 50 members who evaluated the sermons identified a specific spiritual need the lay message met; 42 of the 50 evaluators gave a 3-4 rating that the sermon filled that spiritual need. 
5. The results of the sermon evaluations by church members demonstrated significant improvement and preaching skills of lay persons who participated in the preaching course. Therefore, this model to train lay persons to preach demonstrated progress, improvement and recognizable growth in the preaching of lay persons in the Chicago area churches who took the preaching course.

\section{Coaching Component Evaluation}

Results: 5 lay persons participated in the evaluation

Section I: Rate on a scale of 1-low, 5-high.

1. Question: A preaching coach is a new concept to me. 4 respondents marked 5, 1 marked 2.

2. Question: It was explained, and I understood, how "coaching" could help me. 3'marked 5, 2 marked

3. I looked forward to the personal help in the preaching experience. 3 marked 5, 2 marked 5.

4. Coaching helped me to prepare for preaching the sermon. 4 marked 5, 1 marked 4 .

5. Coaching helped me to clarify my subject, introduction, word study, etc. 5 marked 5 .

6. Coaching helped me to write the sermon with cohesive thought. 4 marked 5, 1 marked 4.

7. Coaching helped me to focus on the spiritual foundation of the sermon. 5 marked 5 . 
8. Coaching helped me with the sermon illustration, application and appeal. 3 marked 5, 2 marked 4.

9. Coaching helped in my delivery and execution of the sermon. 4 marked 5, 1 marked 4.

10. Coaching helped me to be more confident in preaching the sermon. 5 marked 5.

11. Coaching helped me to evaluate and make adjustments after the sermon. 4 marked 5, 1 marked 4.

12. Coaching helped me to prepare for my next sermon by giving me clear steps and structure to follow in the sermon preparation. 4 marked 5, 1 marked 4 .

13. The coaching experience took extra time and effort, but it was worth it. 5 marked 5.

14. Coaching helped to motivate and make the sermon experience more enjoyable. 4 marked 5, 1 marked 4.

15. I would take the "coaching component" experience again. 5 marked 5.

Section II: Written thoughts (5 Sample comments)

"The coaching experience was like have a trainer to walk you through all aspects of preaching. It helped to put it all together for me."

"Can we continue this program forever? At least one more time, I need more of this for I am a slow learner."

"Every church should have this for their elders because all lay preachers need this. I hope other pastors will try to do this for their elders." 
"Just knowing you can reach your pastor/coach whenever you have a question or get stuck in your preparation is great. Can this be continued for another six months?"

"This gave me real-life examples of what happens behind the scenes in preparing the God's message for His people; Satan really works, but God does great handson help."

Focus Group's Evaluation of the Preaching Course

Results: 10 Students, 8 who completed, 2 did not.

1. Pluses of the Course:

"It was thorough. It helped us understand what preaching is and then how to learn." "It was a progressive learning experience and it challenged each student to love to preach and learn."

"I learned how to love and understand the Word of God."

"It wàs a spiritual and motivating learning environment."

"The pastors/teachers were great. The really knew how to help us learn. Thanks for taking it slow so we could digest such vital information. Keep teaching and training."

2. What was difficult for you?

"The schedule and amount of time needed was rigorous."

"It was hard to attend class every Sabbath afternoon and to fit that into my church and family schedule. Yes, hard!"

"I had to miss two classes ... but I got to make it up and caught us with the help of teachers others."

"I found it intimidating to do practice sessions in class." 
"It bothers me that more lay persons didn't grab this opportunity to learn how to preach from the real preachers."

3. What changes would you suggest?

"I believe the thing to change would be the schedule. It was like a semester in college.".

"I would have the planners consider breaking each course into two or three segments.

Take a month break and go another four weeks and so on."

"Consider a different schedule: Do weekends. Saturday afternoon and Sunday once a month. Then do that five to six months each year."

"I would say let's look at offering different schedules: at least a couple options to meet different schedule needs."

4. What should pastors keep in mind?

"Pastors need to remember how busy the lives of lay persons are. We try to do too much in too little time."

"Remember that lay people want to be involved in ministry real bad. Yet, in this country, we are not used to being as active as in other parts of the world. Be patient with us but challenge us to serve."

"The relatively low numbers of participants should not discourage our teachers. Keep teaching and training us, others will eventually wake up and get involved."

5. What are the important issues to lay persons?

"The lay person wants to grow in ministry."

"Church members want to serve God real bad. We just need to be shown how."

"We want our lives to count for God, we want to use our gifts, but we need help and training." 
"Lay members can be motivated and we want to do God's work help to build up His Kingdom also. Give us a chance and include us more in ministry." "We want our pastors to teach and train us more, and not be afraid for we are hungry to learn."

The evaluation of the model focused primarily on the feedback of students who participated. Perhaps there could have been an evaluation or survey of lay persons who did not choose to participate to glean their thoughts and perspective, and even what it would take for them to enroll in the course. Also, this evaluation did not thoroughly investigate the perspective of church members who may benefit from the improved preaching of their fellow lay persons who took the course.

The evaluation instruments, the survey of lay persons preaching experience, the course evaluation, the coaching component evaluation, and the focus group's evaluation -gave a variety of opportunities to look at the course from the need and perspective of the participants. The lay persons did give direct and clear feedback through these instruments. These instruments all gave evidence of positive effect from the model preaching course. The evaluations showed improvement in the preaching of lay persons who took the course. This recognizable improvement was cited by (a) church members who heard sermons by the students, (b) peers of the students who rated student sermons and class work, (c) the student themselves who reviewed their class work and selfevaluated their sermons written and preached, (d) the instructors who worked with the students in many classes, courses and during a time span of 3 to 12 months.

Lay persons confirmed their desire to be trained to preach. They also voiced that they wanted this kind of training to continue. They desire more participative roles in ministry and are realizing that they can share the preaching ministry with clergy. Lay 
persons are excited about learning and are patient with pastors and leaders who have overlooked their significant role of training laity for ministry. Lay persons realize that training is a process and they are willing to sacrifice their time and make the concessions to minister through preaching.

\section{Evaluation Summary}

Specific evaluations of this course to train laity to preach have been summarized in their evaluation responses and the results prior noted. They see this course as a start. They realize this course is a primer for lay persons and other pastors to consider the significance of training events for laity to learn to reach. They acknowledge this course has areas of which they indicated needed revision and improvement, and they are ready to give their help. They gave high ratings to the course format, methods, content, and teaching. The areas of improvement they noted were: (a) length of the course, (b) timing of the classes could offer options to a multi-schedule lifestyle and world we live in, (c) offer the same information in segments -2 to 3 sections over 5 months instead of a continued 10 to 12 weeks of classes. We can learn from and consider implementing these changes into the next course, and involve more lay persons in the planning and implementing of the next preaching course for lay persons.

The Laity are ready for continued training. They want other lay persons to wake up and participate. Those who have been exposed to this preaching course for lay persons can be the best agents of information, motivation and affirmation. They can be the best spokespersons, the best witnesses, and the best partners to help teach continued courses in preaching. Lay persons affirmed that they benefitted from the course and will 
work with pastors and church leaders to help other lay persons receive training to preaching. 


\section{CHAPTER SIX}

\section{SUMMARY, CONCLUSIONS AND RECOMENDATIONS}

\section{Summary}

This dissertation focused on a model that was developed to train lay persons to preach. A survey of the biblical foundations for lay preaching, in both the OT and NT, was conducted. A literature review was also conducted considering the historical and current literature on lay preaching. The model to train lay persons to preach was examined. It charts the ministry need for this project and its impact on this project. The model outlines two areas: (a) the development-foundations of the development, realministry setting and application in real-ministry, (b) implementation: its three-step process of development, application, and continued training. Evaluation of the model was an essential aspect of the project. Evaluation instruments were used to analyze and review the project.

The biblical foundations for lay preaching in the OT and NT were solid and impressive. The OT gave us a grand theme of God's plan for proclamation of His Word was to take place in the family, among the prophets and the basic and main instrument of his proclamation was people-lay persons. The lay person became the prophet, priest and preacher. It was also discovered from the NT foundation that Jesus' plan was to teach and train the lay person. His ministry focused on empowering lay persons, who became his disciples, apostles, and leaders of the Christian church. 
A literature review revealed that lay preaching was the root that develop the core of Christianity to grow and develop into an unstoppable, world-wide movement of believers. Like the times of the apostles, Christianity continued to grow and develop into a movement that encircled the globe reaching all people because its basic element of individual believers sharing their faith and preaching the gospel to every creature was in place. Current literature like the historical literature, attest to the age-old conflict between clergy and laity-who should be the main preachers. After years of distance and division, current literature accounts of slowly development of more written work and some training for laity to regain their joint position with clergy in the preaching of the gospel. Foundations for lay preaching are sure and solid, awaiting the continued service of the laity in the work of God.

The project looked at a model to train lay persons to preach. It offered opportunities for training for lay persons in the greater Chicago area. It offered courses that taught lay persons the principles and practices of preaching. This model developed over a four-year period of time and helped lay persons grow at each stage of the process of preaching. Courses were offered that would expose lay participants to the many aspects of sermons and preaching. The courses were offered at different times and places to give the lay person maximum access and opportunity to develop their preaching skills over time.

The Evaluation of the project involved the lay-student participant, a selected audience, focus groups, and the teachers/instructors of the course. The main evaluation group was the student participant. Their evaluation and feedback was the key to analyzing and assessing the effectiveness of the project. A survey of the past of 
experience attested to the necessity of the project and their need in ministry. They evaluated the course, the on-going learning project - the coaching component, and they shared their experience in the course in a focus group evaluation session. The evaluation gave pertinent feedback for making adjustments to the course, changes in the course, and ideas for the overall improvement and greater impact the course can have on more lay persons.

\section{Conclusions}

Some important conclusions came to light on this project. First, lay ministry involvement in the Chicago area-specifically the ministry of proclamation-is ripe for recovery. There is a swelling cry from Chicago area laity to be allowed to partner with clergy for the proclamation of the Gospel. Second, Chicago area clergy are tired of trying to do the work of ministry themselves. Clergy in this area have been longing for help from the laity and to return to the NT model of ministry Jesus modeled and set in motion. Third, Chicago area lay persons are the best recruiters of other lay persons for ministry. Their enthusiasm about their experience is contagious and will spread like wildfire among the laity. Fourth, since laity are excited and ready this is the perfect opportunity for pastors and church leaders of the Chicago area to collaborate in making immediate and long-term plans for training of lay workers. Fifth, it is evident that this project is just the "tip of the ice berg." Seminar, courses, and classes need to be taught throughout field so lay persons can be trained and mobilized for ministry that will give hope and impact a hopeless world. Sixth, for more preaching courses, seminars and classes to be taught and lay persons to be trained, pastors need to be trained to do the work of "equipping the saints." 
This project is a start in addressing the need for lay persons to be trained to preach. It begins to help build up the army of lay preachers for the growing need in the ministry of preaching. It is an important step in the right direction, but many other steps need to be taken to meet the needs of the lay workers needing to be trained to preach. The following recommendations are a result out of this project.

\section{Recommendations}

These are the recommendations that this project proposes to the field of ministry, and specifically to the preaching ministry-the training of lay preachers.

Recommendations for Improving The Preaching Project:

1. Pastors should be given awareness sensitivity training for the separation that still exists among clergy and laity.

2. Pastors should initiate mutual meetings of clergy and laity to intentionally find ways of inviting and involving lay persons to join pastors for the full work of ministry, specifically preaching.

3. Pastors should be made aware of the huge outcry and need of lay persons to be trained to preach.

4. Pastors should be exposed to training models available for teaching their elders to preach.

Recommendations for Organizational Support:

1. Conferences should fund the training of pastors to use proven models for the training of lay persons to preach.

2. Conferences are to insist on and provide for the need of pastors being trained 
the principles and strategies for educating adults.

3. Churches and lay persons need to be saturated with the information on training events for the laity.

4. Conferences, pastors and lay persons need to collaborate for the organizing and planning of training events in preaching for lay persons.

5. The General Conference of Seventh-day Adventists should select proven and effective models for training lay preachers to be published and made available to lay persons through the established structure of the church's publishing sources.

It was the goal of this project that the need for lay persons to be trained for the ministry of preaching will come to the attention of all involved in ministry-church organizational bodies, churches, pastors and lay persons. This project hopes that its goals, conclusions and recommendations will have made an impact on the thinking and practices for training our laity for the most effective ministry in these most challenging and difficult times in the history of mankind. 
APPENDIX A

SURVEYS 


\section{A SURVEY OF LAY PERSONS' PREACHING EXPERIENCE}

Rate your experience by circling the answers that match your experience.

1. How often have you been asked to preach?

- never

- one to three times a year

- more than five times a year

- more than ten times a year

2. How well do you feel you are prepared to preach?

- completely unprepared

- very little

- somewhat

- well prepared

3. What kind of training in preaching have you received?

- no training in any form

- seminar for elders

- preaching workshop

- class in public speaking

- class in preaching

- other:

4. What do you feel you need to be able to preach effectively?

- books to read

- time with experienced pastors

- personal mentoring with a preacher

- a series of specific classes in preaching

- other:

5. What has been the role of your pastor in your preaching?

- a visible model and example

- giving you opportunities to preach and learn

- teaching, evaluating and exposing you to preachers and sermons

- played no role

- other:

6. What has been the role of your conference in your preaching?

- giving you information and making resources available

- providing workshop and classes

- helping your pastor train and mentor you

- played no role

- other:

7. What is your goal in preaching?

- to learn the basics and know more resources

- to develop my ability

- to preach regularly for worship services

- to preach evangelistic series

- other: 


\section{AUDIENCE POST-SERMON SURVEY}

SERMON TITLE:

Speaker:

Date:

1. Circle a number that best rates the sermon element.

SERMON ELEMENTS

(low)

SCORE

(high)

\begin{tabular}{|c|c|c|c|c|}
\hline Overall quality & 1 & 2 & 3 & 4 \\
\hline Use of the Bible & 1 & 2 & 3 & 4 \\
\hline Captured Attention & 1 & 2 & 3 & 4 \\
\hline Length & 1 & 2 & 3 & 4 \\
\hline clarity & 1 & 2 & 3 & 4 \\
\hline Subject Covered Well & 1 & 2 & 3 & 4 \\
\hline Relevance to Life $\approx$ & 1 & 2 & 3 & 4 \\
\hline Effective Appeal & 1 & 2 & 3 & 4 \\
\hline
\end{tabular}

2. How would you rate the relevance and helpfulness of this sermon for the congregation whole? ( 1 - low, 5 - high)

$\begin{array}{lllll}1 & 2 & 3 & 4 & 5\end{array}$

3. What spiritual need do you think the sermon was designed to fill?

4. How well did the sermon fill that need? (1- low, 5 high) $\begin{array}{lllll}1 & 2 & 3 & 4 & 5\end{array}$

Gender (circle one): Male

Female

Circle your age category:

$\begin{array}{lllllll}0-12 & 13=18 & 19-24 & 25-35 & 36-45 & 46-60 & 60+\end{array}$




\section{PREACHING COURSE SATISFACTION SURVEY}

Thank you for participating in the preaching course, Foundations of Preaching. Please rate your satisfaction with the class activities and overall experience. Read and check your response. Thank you.

1. How effective was the advertisement in getting attention?

0 very effective 0 effective 0 little effect 0 ineffective

2. How satisfied were you with the registration process?

0 very satisfied 0 satisfied 0 dissatisfied 0 very dissatisfied

3. How satisfied were you with the course and class format?

0 very satisfied 0 satisfied 0 dissatisfied 0 very dissatisfied

4. How satisfied were you with the class outlines and lectures?

0 very satisfied 0 satisfied 0 dissatisfied 0 very dissatisfied

5. How satisfied were you with the course location?

0 very satisfied 0 satisfied 0 dissatisfied 0 very dissatisfied

6. How satisfied were you with the course schedule and class times?

0 very satisfied 0 satisfied 0 dissatisfied 0 very dissatisfied

7. How satisfied were you with what you learned?

0 very satisfied 0 satisfied 0 dissatisfied 0 very dissatisfied

8. How satisfied were you with your progress in preaching?

0 very satisfied 0 satisfied 0 dissatisfied 0 very dissatisfied

9. How satisfied were you with the instructors?

0 very satisfied 0 satisfied 0 dissatisfied 0 very dissatisfied

10. How satisfied (if you participated) were you with the "coaching experience - the follow-up mentoring with a pastor?

0 very satisfied 0 satisfied 0 dissatisfied 0 very dissatisfied 
APPENDIX B

EVALUATION FORMS 


\section{IN-CLASS SERMON EVALUATION FORM}

Student/Preacher Date

Title Text

Sermonic Type: Topical Textual Expository Narrative * place a check by each sermon feature you evaluate, 1 poor, 5 - excellent.

4 5

INTRODUCTION

Gets audience attention

Focuses o subject

CONTENT

Biblically Sound

Christ-centered

Interesting

Relevant

Applied to my life

STRUCTURE

Organized

Flow of thought

Transitions of message

Unity of sections

Length of message

STYLE

Intellectual challenge

Creativity \& Imagery

Passion \& Emotion

Use of Illustrations

DELIVERY

Usage of Language

Voice and Diction

Gestures \& Posture

Conviction \& enthusiasm

CONCLUSION \& APPEAL

Effectiveness

Spirituality \& Sensitivity 


\section{2-POINT PERSONAL SERMON EVALUATION}

\section{Spiritual Preparation}

Was sufficient time invested in prayer and meditation prior to writing and in preparation?

Were sins confessed before the Lord before drafting this sermon?

- Had God's message in the sermon taken root within you before preparing and delivering it?

Was the sermon fully edited to ensure the message was not spiced with personal opinions?

Did you schedule time just before sermon delivery for solitary mediation?

\section{Opening Prayer}

Word?

Did your prayer prior to the sermon focus and prepare the audience to hear God's

Title

Was the sermon title part of the hook to grab and keep the audience's interest?

Was the title repeated during the sermon for connection and continuity with theme?

\section{Introduction}

Were the opening statements captivating enough to engage everyone quickly?

Was the audience drawn in?

\section{Background}

Was there sufficient social and historical background so that those who do not read the Bible could understand the context of in which the scripture was presented? Was the goal of the author of the book stated clearly?

\section{Scripture Presentation \& Language}

Was the scripture read in a tone and passion that drew the audience into the text?

- Did the style of speaking reach all educational and socioeconomic levels in audience?

\section{Interpretation}

Did you allow scripture to interpret scripture? Was the text given its historical setting?

Was the message presented in the context of the entire Word and Revelation of God?

Did the sermon speak to a need the congregation could relate to?

Did the sermon answer the question, problem, or need presented in the text?

\section{Illustrations}

\section{Length}

Did your illustrations directly relate to the lesson and principles of the sermon?

Was the length of sermon proper for comprehensive presentation of scripture?

Pacing

Was the delivery paced evenly - not rushed, or drawn out?

\section{Christ-Centered}

Did the message focused on and point to Christ Saving power and exemplary life?

\section{Appeal}

Did the appeal format match the content and style of the message?

Was the audience given practical and meaningful ways to respond to the message?

-Was a "gospel invitation" given at the conclusion of the message? 


\section{AUDIENCE SERMON EVALUATION OF LAY PERSONS PREACHING FOR WORSHIP SERVICES}

Thank you for participating in the evaluation of the lay preacher you heard today. Please indicate your response to the evaluation question by checking the answer and by your written response the questions. Your response will help the preacher as well as the instructors of the lay preaching courses.

1. Evaluate the these aspects of the sermon on a scale of 1.5 (1 1 low, 5 - high).

Write a number from $1-5$.
a) Content
b) Bible Based
c) Clarity
d) Length
e) Subject Covered Well
f) Application to Life
g) Appeal: Call to Action

2. Rate the relevance and helpfulness of this sermon ( $1-$ not helpful, 5 very helpful).

3. What spiritual need do you think this sermons was designed to fill? (write answer)

4. How well did this sermon fill that need? ( 1 - not well, 5 - very well)

5. Tell us about yourself:

Male Female

Age a. $0-12$ b. $13-18$

c. $19 \cdot 25$

d. $26-35$ e. $36-45$ f. $46-60$

g.

$60 \&$ above

Member

Visitor 


\section{AUDIENCE EVALUATION OF LAY SERMONS}

Your feedback can help rate the lay preachers' improvement.

1. The message was Bible-based.

0 not at all

0 a little

0 somewhat

0 very much

2. The message was Christ-centered.

0 not at all

0 little

0 somewhat

0 very much

3. The preacher was prepared.

0 not at all

0 little

0 somewhat

0 very much

4. The message was practical and clear.

0 not at all

0 little

0 somewhat

0 very much

5. The preacher showed improvement in preaching.

0 not at all

0 little

0 somewhat

0 very much

6. The preacher helped me apply the word to my life.

0 not at all

0 little

0 somewhat

0 very much

7. The preacher was used effectively by God.

0 not at all

0 little

0 somewhat

0 very much 


\section{FOCUS GROUP' S COURSE EVALUATION}

The focus was composed group of 10 students who participated in the preaching course. Of the ten students, eight completed the course and 2 did not. This group responded to the following questions by sharing their thoughts and experiences with the two instructors/pastors.

\section{Questions Posed to the Focus Group for Discussion}

1. What were the positive things you experienced in participating in this preaching course?

2. What about this course was difficult and/or challenging for you?

3. What changes would you suggest be considered to improve this preaching course?

4. What should pastors and church leaders keep in mind as they make plans to train lay. persons to preach?

5. What do you believe to be the important issues to lay persons? 


\section{Instructor Evaluation}

This evaluation gives students opportunity to give feedback about your experience with the instructors of this course.

1. How knowledgeable were the instructors in the subject of preaching?

0 Not very

0 little

0 somewhat

0 much

0 very much

2. How prepared were the instructors to teach the classes?

0 not

0 little

0 somewhat

0 very much

3. How clear were class presentations on preaching?

0 not

0 little

0 somewhat

0 very much

4. How well did instructors interact and give personal help to students?

0 Not

0 little

0 somewhat

0 very

4. How effective were class outlines and lessons for learning?

0 not

o little

0 somewhat

0 very

5. How helpful and effective were class exercises?

0 not

0 little

0 somewhat

0 very much

6. The instructors

0 reduced

0 stimulated

0 inspired

0 enhanced 


\section{COURSE EVALUATION}

This evaluation is for honest feedback of your experience in the course, Introduction to Preaching. The scale is $1-5,1$ being lowest and 5 being highest: $1=$ don't agree, $5=$ strongly agree

\section{Section I Rate 1 - 5}

\section{QUESTION}

\section{SCORE}

1 This course was long overdue.

2 I needed this course.

3 Lessons were specific and helpful.

4 The content and format was beneficial.

5 The course was difficult.

6 The instructors taught the lessons well.

7 The course was Biblical and practical.

8 The class times were agreed upon and good.

9 The course length was good.

10 Class activities enhanced learning.

11 Class participants learned together as a team

12 I would recommend this course to lay persons

Section II Mark "T" for True, "F" for False

1. I have not heard of a course like this before.

2. This is my first course in preaching.

3. I believe every elder should take this course.

4. This course can benefit each church and pastor.

5. I would take this course again.

6. I need to learn even more about preaching.

7. There should be a follow-up course to this one.

8. Preaching is an important lay person ministry.

9. I am realizing preaching requires much work.

Section III Comments: Please share your thoughts and observations. 


\section{EVALUATION OF THE COACHING COMPONENT EXPERIENCE}

Give your honest feedback of the experience you had with a preaching coach with your preaching preparation, delivery and sermon evaluation.

In Section I, the scale is 1-5, with 1 being lowest $=\mathrm{I}$ don't agree, and 5 being highest $=\mathrm{I}$ strongly agree. Section II gives opportunity for you to share your experience in words.

Section I

STATEMENT

SCORE

1. A preaching-coach is a new concept to me.

2. I t was explained, and I understood, how "coaching" could help me.

3. I looked forward to personal help in the preaching experience from prayer-preparation, to material preparation and delivery.

4. Coaching helped me to prepare for preaching the sermon.

5. Coaching helped me to clarify my subject, introduction, word study, etc.

6. Coaching helped me in writing the sermon with cohesive thought.

7. Coaching helped me to focus on the spiritual foundation of the sermon.

8. Coaching helped me with sermon illustration, application and appeal.

9. Coaching helped me in my delivery and execution of the sermon.

10. Coaching helped me to be more confident in preaching the sermon.

11. Coaching helped me to evaluate and make adjustments after sermon.

12. Coaching helped me to prepare for my next sermon by giving me clear steps and structure to follow in the sermon preparation.

13. The coaching experience took extra time and effort, but it was worth it.

14. Coaching helped to motivate and make the sermon experience enjoyable.

15. I would take the "coaching component" experience again.

Section II Comments: Please share your thoughts and reflections of the "coaching experience." Your feedback is valuable for improvements in the course. 
APPENDIX C

MODEL SEMINARS 


\title{
A MODEL PREACHING SEMINAR:
}

\author{
PREACHING
}

LIKE

J E S U S
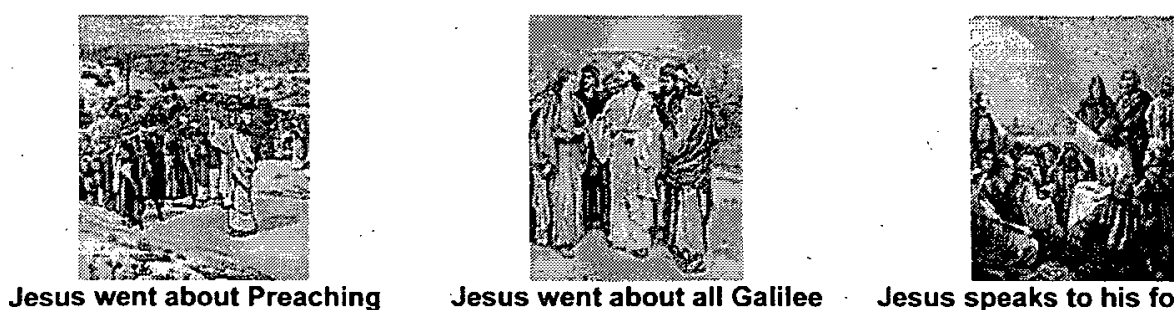

Jesus went about all Galilee

Jesus speaks to his followers

Leeroy M. Coleman 
PREACHING LIKE JESUS - LESSON OUTLINE

\section{SERMON EMPHASES AND SERMON TYPES}

\section{SERMON EMPHASES}
A. Doctrinal - to instruct in the Christian faith and creed.
- It asks: "What do Christians believe?"
B. Ethical - To instruct and guide in Christian behavior and sanctification.
- It asks: "How should Christians behave?"
C. Promotional - To stimulate effective and aggressive witnessing of the faith.
- It asks: "How do Christians give effective witness of their faith in Jesus Christ.?"
D. Evangelistic - To give spiritual life to sinners by leading them to Christ.
- It asks: "how do sinners become born again?"

\section{SERMON TYPES}
A. Topical - Preaching on relevant topics using Bible texts as support and verification.
B. Expository - Use of verses, chapters, or Bible books to present a unit of truth.
C. Textual - Use of one or more Bible verses to derive outline and main points of sermon.
D. Narrative - Preaching on the stories of the Bible in story form.

\section{III.PROBING EFFECTIVE WAYS TO PREACH TO LISTENERS}

1. What Emphases and Styles best speak the language of the hearers?

2. What positive or negative effective do type and style have on message?

3. What sermon emphases help most in delivery and why?

4. What sermon types best affect the delivery of the message and why? 


\section{NARRATIVE PREACHING I}

Preaching Like Jesus: Trusting the Stories of The Bible

\section{WHAT NARRATIVE PREACHING IS NOT:}
A. Not Story Telling
B. Not Giving Illustrations
C. Not Entertainment
D. Not Drama

- Many pass off the term "narrative" as just a story one drops in the message to fill Out the sermon and entertain the audience.

- Many have dismissed the "story" as a childish method and means of teaching.

- Concerns: lack of didactic information, entertainment, too little doctrine, Lacks ethical appeal, lacks evangelistic passion and power, limited to the biblically literate, does not address today's issues; too much power, reshaping, and ideology at work in the narrative.

\section{WHAT NARRATIVE PREACHING IS:}

A. Dramatic Re-telling God's Grand Epic

B. Embracing The Biblical Account of God Interactions with Man

C. Reliving The Gospel Stories of Jesus

D. Bringing God's Grand Narratives to Life

E. Demonstrating the Roles and Place of Believers in God's Epic

\section{III.KEYS TO UNDERSTANDING AND APPLICATION}

- Preaching/Teaching like Jesus did: The Power of Truth in Story Form

- Preaching The Bible Stories as the Stories they Are - let the truth and lessons be imbedded and flow out of the real-life Biblical stories.

- The use of stories is not the point: the means and structure of the sermon is less "didactic," "inductive," "propositional," "point-by-point" or apologetic.

- The sermons is shaped as a real-life drama: it has a plot, characters, conflict, resolution - eg: a lost coin found; a lost sheep, found; a lost son restored.

\section{IV.JESUS' PREACHING: THE NARRATIVE APPROACH}

1. Jesus Use of Real-Life Stories - examples:

2. Jesus Use of Parables - examples:

3. Jesus Use of Object Lessons - examples: 


\section{PREACHING LIKE JESUS: TELLING THE STORY II}

An Approach to the Preparation of the Narrative Sermon

1. Read the selected passage several times in several different versions.

2. Get into the Story: Note its flow, setting, timing, plot.

3. Select character/s to highlight and/or tell the story from their perspective.

4. Select a portion of the story to highlight and focus on.

5. Bring out the touch-points and lessons the biblical account emphasizes.

6. Trust the story to teach, re-live, persuade, captivate the listener.

7. Arrange all information by verse.

8. Describe: scene, persons/characters, conversation, etc. include all senses: smells, sounds, sights, taste, touch - as necessary to capture the reality and essence of the story from a blind person's perspective pan the scene with your literary camera capture the thoughts of the characters put yourself in the scene and be part of the drama

9. Use your imagination with untold parts of the biblical account.

10. Make applications for each verse and section.

11. Connect the characters, storyline, and as many details with Jesus.

12. Uplift Jesus throughout the story

13. Write out the story to get flow and timing: evaluate with the biblical account.

14. Write out the final draft in sequential order to help you tell the story-sermon.

15. Read three Narrative Sermons: to be handed out by instructor. These will give good examples of how a narrative story flows and come to life for the listeners. 
PREACHING LIKE JESUS: Lesson Outline

\section{CONNECTING SPIRITUALITY TO SYMBOLS AND REPRESENTATIONS}

The principle of connecting symbols and representations in the Bible passages is naturally used throughout scripture to give meaning and powerful impact to the "hearers" of the Word.

Bible passages use common objects, animals, places, people, plants, events, and characters as symbols and give them spiritual meanings and representations. This biblical characteristic gives the preacher a wealth of opportunity to connect spiritual meaning to just about every area of the believer's life.

\section{EXAMPLES:}

I. Genesis 4-Cain and able were told to sacrifice a lamb which spiritually represented Jesus, the Savior who would be sacrificed for us.

II. Genesis 6 - Noah was told to build an ark which spiritually represents the Church that is to be the "ark of safety" for God's people.

III. Exodus \& Leviticus' sanctuary and it's holy items all spiritually pointed to God's plan of Salvation and how they all work to the salvation and restoration of every believer.

IV. Jesus spoke of the "Wheat \& Tares" that spiritually points to the two groups of hearers and how they responded to obeying God's word.

V. Jesus spoke of the "Ten Virgins: Five Wise, Five Foolish" and how they spiritually represented those who were ready and those were not for His second coming.

VI. A specific example of how these can be used in the sermon: John 15:1-5

"I am the vine, you are the branches....bear much fruit..."

a. The Concept: The idea of closeness and connectedness of the believer to Jesus and how the grape vine and it branches points to our relationship with our Lord.

b. The Preaching Implications: can use this great practical example and "picture" to help the listener grasp the deep spiritual truth of what is most important to God and the many benefits of the believer who is connected to their Lord.

c. The Preaching Strategy:

- Identify the symbols and spiritual representations in the passage

- Engage the symbols for specific application to hearers

- Consider using pictures, real objects to match symbols in the passage

- Be aware and remember that spiritual symbolism gives the preacher a direct application. Use this naturally. 
PREACHING LIKE JESUS: Lesson Outline

COMPARING CONTRASTING PREACHING STYLES

Jesus' Method of Preaching

I. JESUS' METHOD OF PREACHING: Matthew 16:13-20

II. CONTRASTING PREACHING STYLES:

A. Jesus and the Pharisees

\begin{tabular}{|l|l|}
\hline \multicolumn{2}{|c|}{ JESUS } \\
\hline Personal & \multicolumn{1}{|c|}{ THE.PHARISEES } \\
People Honored & Impersonal \\
Trusted Relationships & People Ruled \\
Gave Evidence before Conclusions & Trusted Rules \\
Appealed to Reason & Gave Pre-set Conclusions \\
Concerned with Hearer's Needs & Appealed to Authority \\
Placed People First & Concerned with Facts \\
Teaches from Experience & Placed Doctrine First \\
Asked Questions & Teach from Theory \\
& Made Demands \\
\hline
\end{tabular}

B. Deductive and Inductive

1. Deductive preaching proclaims, then explains.

-

2. Inductive preaching explains, then proclaims.

$-$

$-$

$-$

\section{I. THE PURPOSE OF PREACHING}
A. To communicate God's Word to all people
B. To speak in the people's language
C. To use methods and means that match people and times
D. To pass on real experience of the preacher with the people about God. 


\section{PREACHING LIKE JESUS}

Lesson 1: Jesus' Methods of Preaching

\section{CLASS OUTLINE}

In this lesson, we will consider and learn the methods and strategies Jesus used to preach and teach. His methods were effective and varied. He preached to the universal needs, desires, and experiences of His audience. He preaching addressed their families, finances, work, present and future. His teaching was excellent preaching, and His preaching was effective teaching. What tools and means did He use in His preaching? We can learn from and learn to master His methods.

1. HIS QUESTIONS. Matthew 16:13-20
A. They were
B. They were
C. They were
D. Other: Luke 2:29 - His
words.

II HIS OBJECT LESSONS John 15: 1-8
A. They were
B. They were
C. They were
D. Other:

III HIS STORIES - PARABLES Luke 15
A. They
Heaven's truth.
B. They
God's Gospel.
C. They
Eternal lessons. 
IV HIS CHARACTERS - PERSONS Luke 18:18-23
A. Their
B. Their
c. Their
D. Their
E. Their
F. Other:

\section{$\checkmark$ HIS OTHER METHODS AND MEANS}

1. His use of

2. His use of

3. His use of

4. His use of

5. His use of

6. His use of

7. His use of
Scrip:

Scrip:

Scrip:

Scrip:

Scrip:

Scrip:

Scrip:

VI HIS COMPLETE LESSON IN PREACHING - Filled with many methods. John 4:1-43

1. He was

2. He was

3. He was

4. He was

5. He was

6. He was

7.

- Look for similarities in Jesus' meeting with Nicodemus. List methods he used. 
PREACHING LIKE JESUS - LESSON OUTLINE

POWER-FILLED PREACHERS, POWERFUL SERMONS, POWERFUL PREACHING

"We are not ashamed of the Gospel for it is the power of God unto salvation..."

\section{POWERFUL VS POWERLESS SERMONS}
A. Lukewarm - is powerless
B. Three reasons for lukewarm messages:

C. Cure for lukewarm: Power

1. Inspiration:

2. Imagination:

3. Preparation:

\section{POWERFUL SERMONS HAVE:}
A. Purpose - when preacher has a purpose, then sermon has purpose
B. Plans - when preacher has a plan, sermon has flow and impact
C. Preached with People in mind - listeners personally connect to message
D. Preached for the Glory of God - it shows God's greatness and grace

\section{III.WHY PURPOSEFUL SERMONS ARE POWERFUL}

1. Preacher has goals for message

2. Goals leads to plans for message

3. Goals give direction of message

4. Goals give force to message

5. Plans produce results from message

6. People want to hear of results: "What will this do for me?"

\section{IV.SOURCE OF SERMON PURPOSE}

1. God's directive, mandate: To Spread the Gospel - tell the Good News

2. The Preacher understanding he/she is bearer of Good News

3. The Need of the people to hear and receive the Good News

4. The Source of the Good news is from God's Word - Scripture

5. The Word of God is transformative: it changes hearts transforms lives 
PREACHING LIKE JESUS: Lesson Outline

Preaching With Awareness of Learning and Listening Styles

I. LEARNING \& LISTENING STYLES - by Bernice McCarthy, About Learning (Barrington, IL: Excel, 1996), 85-100.

A. Type 1: Imaginative

- Perceive information concretely and process reflectively.

- Integrate experience with self, learn by listening and sharing.

- Love harmony, like groups and discussion.

- Strength: imaginative ideas, nurturing spirit.

- Function by: Clarifying Values.

- Goal: To focus on important issues and bring harmony.

- Favorite Question; Why?

B. Type 2: Analytic

- Perceive information abstractly and process it reflectively.

- Integrate by critique, analysis, and catalog what experts think.

- Like logical, sequential, and detailed presentation.

- Strength: creating concepts and models.

- Function by: Thinking things through

- Goal: Intellectual recognition.

- Favorite Question: What?

C. Type 3: Common Sense

- Perceive information abstractly and process it actively.

- Learn by testing, and applying common sense.

- Practical down-to-earth problem-solvers.

- Focus on productivity and competence - getting things done.

- Strength: practical application of ideas.

- Function by: gathering data from kinesthetic hands-on experience.

- Goal: to align their views of present with future security.

- Favorite Question: How does this work?

D. Type 4: Dynamic

- Perceive information concretely and process it actively.

- Learn for themselves by trial and error.

- Adaptable, and relish variety and change.

- Creative risk-takers; energizing visionaries.

- Strength: Action, getting things moving.

- Function by: Acting and testing experience.

- Goal: To bring action to ideas.

- Favorite Question: What if?

\section{HOW LEARNING STYLES AFFECT PREACHING}

A. Match Sermonic Emphasis \& Type to Learning Style Examples: 
B. Charting Learning Styles \& Sermonic Approach: match sermon to style

\begin{tabular}{|l|l|}
\hline LEARNING STYLE & \multicolumn{1}{|c|}{ SERMON APPROACH } \\
\hline 1. Imaginative & Engage \\
& Create \\
& Tell \\
& Show \\
& Answer Why \\
\hline 2. Analytic & Challenge \\
& Contrast \\
& Detail \\
& Specify \\
& Answer What \\
\hline 3. Common Sense & Show \\
& Depict \\
& Explain \\
& Apply \\
& Answer How it Works \\
\hline 4. Dynamic & Process \\
& Probe \& Explore \\
& Envision \\
& Experience \\
& Answer What if \\
\hline
\end{tabular}

C. Chart Listening Styles \& Sermonic Approach:

\begin{tabular}{|l|l|}
\hline \multicolumn{1}{|c|}{ LISTENING STYLE } & \multicolumn{1}{c|}{ SERMON APPROACH } \\
\hline 1. Imaginative & $\begin{array}{l}\text { Engage senses } \\
\text { Stir Spirit }\end{array}$ \\
\hline 2. Analytic & $\begin{array}{l}\text { Engage mind } \\
\text { Catalog Information \& Concepts }\end{array}$ \\
\hline 3. Common Sense & $\begin{array}{l}\text { Appeal to Practical } \\
\text { Work ideas into Life }\end{array}$ \\
\hline 4. Dynamic & $\begin{array}{l}\text { Appeal to vision \& experience } \\
\text { Outline action steps and risks }\end{array}$ \\
\hline
\end{tabular}




\section{PREACHING TO THE WHOLE PERSON}

I. REACHING THE WHOLE SOUL - Delivering the Gospel Deep: Helping the hearer live out Jesus' words to "...Love the Lord your God with all your heart, mind and soul.
A. Reaching the Body - the physical and practical
B. Reaching the Mind - the mental and metaphysical
C. Reaching the Soul - the spiritual and experiential

\section{TOUCHING THEIR MINDS BY}
A. Their Interests: Experience, illustrations, anticipation
B. Their Curiosity: Attraction, humor, identification, variety
C. Challenging Them: Work, play, weaknesses, strengths

\section{III.TOUCHING THEIR EMOTIONS THROUGH}
A. Their Pain: Feeling, disappointment, anxiety
B. Their Problems: Failure, frustration, fate
C. Their Person: Personality, fears, relationships
D. Their Values: Priorities, struggles, gifts

\section{IV.TOUCHING THEM THROUGH THEIR MODALITIES}
A. Visual
B. Auditory
C. Kinesthetic

\section{TOUCHING THEM THROUGH:}

A. Critical Questions:
1. Why should I learn this?
2. What God wants me to learn and know about this?
3. How can this be practically worked into my life?
4. How do I apply this to my life today?

B. Heart Questions:
1. Concerning Life
2. Concerning Self/Person
3. Concerning God

\section{GIVING THEM GOD'S WORD: BIBLICAL ANSWERS}
A. For Their Body
B. For Their Mind
C. For Their Soul 
PREACHING LIKE JESUS: Lesson Outline

\section{SERMON PREPARATION SKILLS, PRACTICES \& MODELS}

I Practices \& Skills:

1 DEVELOP THE PRACTICE AND SKILL OF "PREPARATION-PRAYER" How to make prayer the key to your ideas and preparation

2 TRUST YOU PERSONAL DEVOTION AND STUDY

How to enjoy your devotional time and let it feed your preaching bank

3 DEVELOP A LOVE FOR EXPLORING THE WORD

Ideas for exploring the hidden places of Scripture

4 DEVELOP A LOVE FOR THE BIBLE STORIES

Getting an eye for the power of the story to inspire you and transmit the Gospel

5 DEVELOP THE COURAGE TO TACKLE TOUGH TEXTS

Resources that equip you to face and gain preaching insights into difficult passages

6 DEVELOP THE PRACTICE OF RECORDING SERMON IDEAS

7 DEVELOP THE PRACTICE OF OUTLINING TEXTS

8 DEVELOP THE PRACTICE AND SKILLS OF WORD STUDY

9 DEVELOP THE SKILL OF ANALYSING KEY WORDS

10 DEVELOP THE SKILL OF OUTLINING SERMON IDEA

11 DEVELOP THE SKILL OF SELECTING MAIN SERMON TEXTS

12 DEVELOP THE SKILL OF WRITING OUT THE "MAIN IDEA"

13 DEVELOP THE PRACTICE OF A PREPARATION ROUTINE

14 DEVELOP THE PRACTICE OF "KEEPING IT SIMPLE" (KIS)

15 DEVELOP THE PRACTICE OF WRITING OUT THE FULL MESSAGE

16 DEVELOP THE PRACTICE OF PRACTICE-PREACHING THE SERMON

17 DEVELOP THE PRACTICE OF LISTENING TO YOUR GROUP

18 DEVELOP THE PRACTICE OF THOROUGHLY KNOWING SERMON

19 DEVELOP THE SKILL \& PRACTICE OF CAREFUL ANALYSIS

20 DEVELOP THE PRACTICE OF TRUSTING GOD TO PREACH THRU YOU

II MODELS \& APPROACHES TO PREPARATION:

1. The "Run-Way" Model

2. The "Speech" Model

3. The "Four-Page" Model

4. Developing Your Own Model 
PREACHING LIKE JESUS - LESSON OUTLINE

POWER-FILLED PREACHERS, POWERFUL SERMONS, POWERFUL PREACHING

"We are not ashamed of the Gospel for it is the power of God unto salvation..."

\section{POWERFUL VS POWERLESS SERMONS}

D. Lukewarm - is powerless

E. Three reasons for lukewarm messages:

F. Cure for lukewarm: Power

4. Inspiration:

5. Imagination:

6. Preparation:

\section{POWERFUL SERMONS HAVE:}

E. Purpose - when preacher has a purpose, then sermon has purpose

F. Plans - when preacher has a plan, sermon has flow and impact

G. Preached with People in mind - listeners personally connect to message

H. Preached for the Glory of God - it shows God's greatness and grace

\section{WHY PURPOSEFUL SERMONS ARE POWERFUL}

7. Preacher has goals for message

8. Goals leads to plans for message

9. Goals give direction of message

10. Goals give force to message

11. Plans produce results from message

12. People want to hear of results: "What will this do for me?"

VIII. SOURCE OF SERMON PURPOSE ·

6. God's directive, mandate: To Spread the Gospel - tell the Good News

7. The Preacher understanding he/she is bearer of Good News

8. The Need of the people to hear and receive the Good News

9. The Source of the Good news is from God's Word - Scripture

10. The Word of God is transformative: it changes hearts transforms lives 


\section{PREACHING LIKE JESUS - LESSON OUTLINE}

\section{PREACHING: PERSONAL \& ALIVE COMMUNICATION}

\section{PREACHING IS PERSONAL}

Eternal truth is universal so the great truths of a sermon may transfer from one preacher's sermon to another's. The skeleton is the same. But the flesh is different. The look and feel is different. God has given you a unique personality so that you can preach His message within the unique framework of your personality and history. Your sermon is a unique conversation between God and the congregation. Could you imagine trying to have a timely conversation with your friend and instead of interacting with you, she was reading from a script she got off the internet? The first reason you should preach your own sermons is that preaching is personal.

A. God personally delivers His message to the preacher

B. Preacher personally delivers God's message through him/herself to people

C. People personally receive message, live it, and proclaim it to other

D. People are motivated by relationship: God uses people to reach people

E. Quotes: "A thoroughgoing Christian draws his motives of action from his deep heart-love for the Master. Up through the roots of his affection for Christ springs an unselfish interest in his brethren." (Adventist Home, 425) "No discourse should ever be preached without presenting Christ and Him crucified as the foundation of the gospel." (Gospel Workers, 158)

\section{PREACHING IS SPIRITUAL - Revelation 1}

A. God has his Holy order - Rev 1: 1-5

B. God is Spirit, He ask us to worship him in "spirit and truth"

C. God made us spiritual beings - "in His image and likeness"

D. We are a natural part of God's order of communion and communication

E. God's plan is to communicate himself, His plan, and purpose through us

Question: How the sermon fulfill the role of spirituality?

\section{PREACHING IS PRACTICAL:}

A. Preaching is to reach, re-connect, and restore relationship of man with God

B. Preaching is to heal: from sin, sickness and disease

C. Preaching is to help: provide daily and lifetime answers to our dilemmas

D. Preaching is a three-way conversation: God talking to preacher, preacher to people \& people talking to God

Question: What techniques can be used to ensure the sermon fulfills the practical? 


\section{READING THE PEOPLE BEFORE PREACHING THE SERMON}

\section{QUESTIONS AND FACTORS TO IMPACT LISTENERS}

\section{A. Questions:}

1. What do they want? - Identification

2. How can God supply their want? Relevance

3. What can they do to fulfill their wants and God's will? Application

B. Factors that Motivate Listeners:

1. The Gospel - Spiritual and psychological

2. Self-awareness and esteem

3. Participation/Involvement

\section{BEFORE YOUR PREACH}

A. Beware of two questions an audience will ask of it's speaker

1. Do I like him/her?

2. Does he/she like me?

B. Bonding with Audience

1. Establish common ground

2. How you are like them/ they like you

3. Seek out similar interests

4. Things you like/ things you love

5. Shared values

6. Show you understand and identify with them

C. Establish Trust with Audience

1. Be vulnerable

2. Share your self, be yourself.

\section{AUDIENCE DISCOVERY}

A. To discover their needs, interests, struggles: Read, Listen, Visit, Pray.

B. List common needs of all people - life's seasons, ups and downs, etc.

C. List goals and problems

D. What the Gospel has given to others, how it can help, the Gold and Good news it is to all 


\section{PREACHING LIKE JESUS - LESSON OUTLINE}

\section{THE KEY ROLE OF LAY PERSONS IN PREACHING}

Following the resurrection, Jesus gave an extensive, unrestrictive commission to preach. Note the scope of the command of Jesus to preach the gospel: "Go ye into all the world, and preach the Gospel to every creature" (Mark 16:15). This last command of Jesus is for a global preaching of the gospel as Luke recorded: "And repentance and forgiveness will be preached in his name to all nations, beginning at Jerusalem" (Luke 24:47 NIV).

I Key Points of Jesus' Command and Commission: The Scope of Preaching
A.
B.
C.

\section{Key Questions in Commission-Preaching}

A. Describe the scope of lay preaching

B. Identify the significant role of lay persons in preaching

C. Name two New Testament characters God called to be lay preachers

D. Recognize the role of lay persons as a key to preaching

E. Identify early lay preachers and their contribution to beginning Christianity

\section{IV.Lay Persons Were, and Still Are, Key in Spreading Gospel}

A. In the Apostolic Church: Laity were key people in preaching the gospel

B. In Persecution Times: Laity were "scattered throughout Judea and Samaria" (Acts $8: 1$ NIV).

C. New Testament Lay Preachers:

- Philip

- Barnabas

- Stephen

$-$ 


\section{PREACHING LIKE JESUS \\ FOUNDATIONS OF PREACHING}

In this lesson, we will consider and learn the methods and strategies Jesus used to preach and teach. His methods were effective and varied. He preached to the universal needs, desires, and experiences of His audience. He preaching addressed their families, finances, work, present and future. His teaching was excellent preaching, and His preaching was effective teaching. What tools and means did He use in His preaching? We can learn from and learn to master His. methods.

I HIS QUESTIONS. Matthew 16:13-20
A. They were
B. They were
C. They were
D. Other: Luke 2:29-- His
words.

II HIS OBJECT LESSONS John $15: 1-8$
A. They were
B. They were
C. They were
D. Other:

III HIS STORIES - PARABLES Luke 15
A. They Heaven's truth.
B. They God's Gospel.
C. They Eternal lessons.

\section{HIS CHARACTERS - PERSONS Luke 18:18-23}
A. Their
B. Their
C. Their
D. Their
E. Their
F. Other: 
V HIS OTHER METHODS AND MEANS

1. His use of

Scrip:

2. His use of Scrip:

3. His use of Scrip:

4. His use of Scrip:

5. His use of Scrip:

6. His use of Scrip:

7. His use of Scrip:

VI HIS COMPLETE LESSON IN PREACHING - Filled with many methods. John 4:1-43

1. He was

2. He was

3. He was

4. He was

5. He was

6. He was

7. He IS

- Look for similarities in Jesus' meeting with Nicodemus. List methods he used. 


\section{FOUNDATIONS OF PREACHING II \\ PREPARING THE PREACHER - LESSON OUTLINE}

The are three key steps the preacher must take to be a prepared mouth-piece and vessel. This lesson focuses on these three elements of personal preparation and how they can be activated in the life of God's messengers.

I SURRENDER - Humbled by God.
A. What
B. How
C. Why
D. When

II SPIRIT FILLED - Empowered by God
A. The Promise
B. The Person - disciple
C. The Plan
D. The Pattern

\section{STUDY - Wisdom from God}

\section{A. The Call to Study}

B. Bible Study - We must approach it with at least four characteristics:

1. Awareness of what the Word of God is

2. Comprehensiveness to God's Word

3. Openness-mindedness to God's Word

4. Expectancy of God's Word 
C. Contemporary Study of the World \& Life

1. Be aware of life as a human being

2. Have a world view each day

3. Be open and in relationship to people

4. Read widely what others are saying of life

D. Resourceful Reading of Literature

1. Join Reading Groups - a wide span of varied ages and professions

2. Willingness to understand the secular mind

3. Allow others to expose, challenge and expand your mind

4. Books, films, plays and discussion serve to excite passion for souls

E. Study Habits - a lifestyle of studying

1. Set regular times for undistracted study

2. Schedule one to two four hour sessions each week in focused study

3. Schedule a day of quiet reflection at least once a month

4. Take an annual week (addition to vacation) for continuing education

5. Select an effective system to organize your study notes

F. Hindrances to Study

1. Under staffed - share your responsibilities

2. Overworked - balance \& prioritize your task

3. Underfunded - ask and be realistic with costs

4. Unshared ministry - share ministry task with trained lay persons

5. No Team in Place - minister by teams, utilize Jesus' methods 


\section{FOUNDATIONS OF PREACHING \\ "HOW TO PREPARE SERMONS" -LESSON OUTLINE}

A distinguished English judge said, "Cases are won in chambers. As far as the barrister is concerned, his critical arena is not the public court but his own private room." The same holds true with the preacher. "If the study is his l lounge, the pulpit will be an impertinence.'" Seven steps will be considered for preparation:

I CHOOSE YOUR TEXT - We are not speculators, but expositors of the Word. Four factors influence and determine our choice of text.

A. Liturgical - following the seasons of the church year's, as set and supplied.

B. External - the events in our nation and world.

C.Pastoral - following the congregation's spiritual pilgrimage, current need.

D.Personal - when God speaks to us personally through a text of scripture.

II MEDITATE ON IT - Saturate your soul in text by asking these questions:

A. What did it mean to the author when first spoken or written?

B. What does it say - what's the contemporary message, how does it speak to us today?

C. What is the meaning?

D. What is the message for today?

III IDENTIFY AND ISOLATE THE DOMINANT THOUGHT
A. Persevere and meditate until it is clear - think long and deep.
B. The dominant thought will be the main theme.
C. It conveys one major message - the proposition.
D. It will guide sermon details back to that main theme.
E. Write out, again and again, until the proposition is crystal clear.

IV ARRANGE MATERIAL TO SERVE DOMINANT THEME

A. Arrange by Structure - order helps the text have maximum impact.

1. Beware of the negatives of structure

2. Emphasize the positives of structure

3. Know different ways of giving structure

4. Beware that different texts and topics demand varied treatment

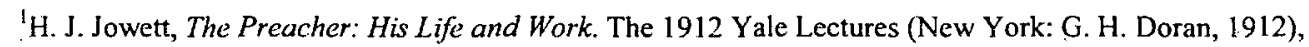
$113-14$. 
B. Arrange by Words - they clothe our thoughts and give pictures to the mind.

1. Know the power of words

2. Learn the proper use of words

3. Use words to make meaning plain, simple, clear, and vivid

C. Arrange by illustrations -

1. The Bible is your first source, it teems with them

2. Learn from and use the Parables of Jesus

3. Learn from great preachers - how they used illustrations

4. Illustrations make the abstract clear, connects their time to our time

\section{ADDING INTRODUCTION AND CONCLUSION}

\section{A. Introduction}

1. Not too long or too short

2. Purpose is to two fold:

a) to arouse interest, stimulate curiosity, whet appetite

b) to introduce theme by leading listeners into it

3. There are different methods of introduction that can be used

B. Conclusion - Appeal, by the convicting power of the Holy Spirit

1. More than just a recapitulation

2. It takes work, it more difficult than introduction

3. Its most important aspect is personal application

4. Select key points of message to apply to their lives by asking questions

- Invite hearers to focus and apply one thing to their lives

- They can be challenged to pray over the message

- They can be invited to get copy of message and re-listen

- You can invite them to surrender an area of their life to God

- Or, invite them to give their life to Christ.

\section{WRITE OUT AND PRAY OVER YOUR MESSAGE}

A. Write out message - even if it's in outline form. ${ }^{2}$

1. Writing it out helps you check the fluidity of your thoughts and transitions.

2. Select the method that works best for you: full manuscript, notes, or abbreviated notes.

3. Writing out message can help with effective delivery.

${ }^{2}$ Stott, Between Two Worlds, 254-58. 
B. Pray over message an hour before preaching- it makes it your own ${ }^{3}$

1. Offer the results of your study and work to God. Pray over

2. Pray for God to prepare your mind to deliver the message.

3. Pray that God's Spirit will prepare the hearers for the message.

4. Pray for God to use the message to change lives, homes and culture.

\section{POST-MESSAGE EVALUATION AND PRAYER}

A. After the message and worship, slip away and pray -

1. Give thanks for the privilege to speak for God

2. Give thanks for the Word that went forth

3. Give thanks for the hearts and souls exposed to God's Word

4. Give the results over to the working of God's Spirit

B. Reflect on how the message went by asking the following questions

1 What was the spirit and tone of message - was it what you wanted?

2 How was your delivery?

3 How did you perceive the audience reception and response?

4 What overall score would you give yourself? (1-poor, 10-excellent)

${ }^{3}$ Stott, Between Two Worlds, 252. R. W. Stott's chapter of "Preparing the Sermon" gives valuable information for the student of preaching. His preaching experience and breath of reading and research is a treasure chest of practical advice on preparing sermons. 


\section{A MODEL SEMINAR: EQUIPING CLERGY TO TRAIN LAY PREACHERS}

"Training the Trainers" - SEMINAR OUTLINE

\section{THE NEED, THE OUTCRY:}

Churches need laborers, Laity request for training

A. The Church's Design and Make-Up:

1. All believers are gifted to serve

2. The Harvest has need of harvesters - laborers

B. The Laity:

1. They recognize their need of training

2. Their desire is to serve and be co-laborers in the harvest

II THE FOUNDATIONS: Biblical Mandates, Principles and Practices

A. The Purpose and Role of The Church

B. The Purpose and Role of The Clergy (Shepherds/Pastors)

C. The Purpose and Role of the Laity

\section{THE TEACHING AND TRAINING OF ADULTS - ANDRAGOGY}
A. The Principles: Science and Practice of Adult Education
B. The Motivators: The Fuel That Moves Adults To Learn
C. The Barriers: Barriers that Hinder Adult Learning
D. Their Needs: The Unique Needs of Adùlts for Continued Education

IV MODELS AND RESOURCES:

Tools for Teaching and Training Lay Persons Preaching

1. What's We Have - exploring empty stores

2. What We Need - do our supply meet our need?

3. Mentoring Lay Preachers: A Coaching Model

4. Possibilities: Extension Education for Laity (EEFL) 


\section{BIBLIOGRAPHY}




\section{BIBLIOGRAPHY}

\section{Books}

About Learning. "The Learning Type Measure (LTM)." http://www.aboutlearning.com/ products/assessments/learning-type-measure (accessed September 23, 2009).

Achtemeier, Elizabeth. "From Exegesis to Proclamation." In Studies in Old Testament Theology, edited by Robert L. Hubbard, Jr., Robert K. Johnston, and Robert P. Meye. Dallas, TX: Word Publishers, 1992.

-_ Preaching Hard Texts of the Old Testament. Peabody, MA: Hendrickson, 1998.

All Are Called: Towards a Theology of the Laity. London: CIO Publishing, 1985.

-Allen, Ronald J. Hearing the Sermon. St. Louis, MO: Chalice Press, 2004.

.Preaching Luke-Acts. St. Louis, MO: Chalice Press, 2000.

. Preaching the Topical Sermon. Louisville, KY: Westminster/John Knox Press, 1992.

. The Teaching Sermon. Nashville, TN: Abingdon Press, 1995.

Allen, Ronald J., ed. Patterns of Preaching. St. Louis, MO: Chalice Press, 1998.

Allen, Ronald J., and Gilbert L. Bartholomew. Preaching Verse by Verse. Louisville, KY: John Knox Press, 2000.

Ammerman, Nancy T., Jackson Carroll, Carl Dudley, and William McKinney, eds. Studying Congregations. Nashville, TN: Abingdon Press, 1998.

Arnold, Jerry. "Equipping Lay People with the Spiritual Gift for Preaching in the Collegedale Community Seventh-day Adventist Church to Preach." D.Min. thesis, Andrews University, 2008.

Ayres, Francis O. The Ministry of the Laity. Philadelphia, PA: Westminister Press, 1962.

Bailey, E. K. Preaching in Black and White. Grand Rapids, MI: Zondervan, 2003. 
Bailey, Raymond. Jesus the Preacher. Nashville, TN: Broadman Press, 1990. . Paul the Preacher. Nashville, TN: Broadman Press, 1991.

Bailey, Robert W. "The Revitalization of the Preaching Event, with Emphasis upon Lay Participation and Perception." S.T.D. thesis, Southern Baptist Theological Seminary, 1970.

Barth, Karl. Homiletics. Louisville, KY: Westminister/John Knox Press, 1991. . The Word of God and the Word of Man. London: Hodder \& Stroughton, 1935.

Behrends, A. J. F. The Philosophy of Preaching. New York: Charles Scribner's Sons, 1890.

Bennett, Bill. Thirty Minutes to Raise the Dead. Nashville, TN: T. Nelson, 1991.

Berelson, Bernard. Content Analysis in Communication Research. Glencoe, IL: Free Press, 1952.

Best, Ernest. From Text to Sermon: Responsible Use of the New Testament in Preaching. Atlanta, GA: John Knox Press, 1978.

Bond, Albert Richmond. The Master Preacher. New York: American Tract Society, 1910.

Brekus, Catherine A. Strangers \& Pilgrims. Chapel Hill, NC: University of North Carolina Press, 1998.

Bresee, W. Floyd. Successful Lay Preaching. Silver Spring, MD: Ministerial Association, General Conference of Seventh-day Adventists, 1997.

Brilioth, Yngve. A Brief History of Preaching. Philadelphia, PA: Fortress Press, 1965.

Briscoe, D. Stuart. Fresh Air in the Pulpit. Grand Rapids, MI: Baker Books, 1994.

Broadus. John A. Lectures on the History of Preaching. New York: A. C. Armstrong \& Son, 1899.

Brokhoff, John R. Preaching the Miracles. Cycle A. Lima, OH: CSS Publishers, 1992.

Buttry, Daniel. First-Person Preaching. Valley Forge, PA: Judson Press, 1998.

Calvin, Jean. Institutes of the Christian Religion. The Library of Christian Classics 20-21. Translated by F. L. Battles. Philadelphia, PA: Westminister, 1960. 
Campbell, Thomas C., and Yoshio Fukuyama. The Fragmented Layman: An Empirical Study of Lay Attitudes. Philadelphia, PA: Pilgrim Press, 1970.

Cannon, Kathleen. "Opening Remarks." In Preaching and the Non-Ordained: An Interdisciplinary Study, edited by Nadine Foley, 7-9. Collegeville, MN: Liturgical Press, 1983.

Capon, Robert Farrar. The Foolishness of Preaching. Grand Rapids, MI: Eerdmans, 1998.

Carlson, Robert. "Malcolm Knowles: Apostle of Andragogy." Vita Scholasticae 8, no. 1 (Spring 1989).

Carroll, John T., and James R. Carroll. Preaching the Hard Sayings of Jesus. Peabody, MA: Hendrickson Publishers, 1996.

Carter, Terry G., J. Scott Duvall, and J. Daniel Hays. Preaching God's Word: A HandsOn Approach to Preparing, Developing, and Delivering the Sermon. Grând Rapids, MI: Zondervan, 2005.

Carus, William, ed. Memoirs of the Life of the Rev. Charles Simeon. London: J. Hatchard, 1847.

Chapell, Bryan. Christ-Centered Preaching. Grand Rapids, MI: Baker Books, 1994. 2001. . Using Illustrations to Preach With Power. Wheaton, IL: Crossway Books,

Childers, Jana. Performing the Word. Nashville, TN: Abingdon Press; 1998.

Claypool, John. The Preaching Event. San Franscisco, CA: Harper \& Row, 1990.

Cline, Francis, and Dennis Turner. Research Methods for Ministry Projects. Grand Rapids, MI: Evangelical Press, 1976.

"The Common Statement." In All Are Called: Towards a Theology of the Laity. London: ClO Publishing, 1985.

Congar, Yves M. J. Lay People in the Church: A Study for a Theology of the Laity. Westminister, MD: Newman Press, 1957.

Craddock, Fred B. Preaching. Nashville, TN: Abingdon Press, 1985.

Dargan, Edwin Charles. A History of Preaching. 2 vols. New York: Hodder \& Stoughton; G. H. Doran, 1905-1912. 
Davenport, Joseph, and Judith Davenport. "Andragogy: Another Bandwagon or Legitimate Tool in the Continuing Education Armamentarium?" Paper presented at the Annual Conference of the National Association of Continuing Education Directors. Washington, DC, October 1984.

Davies, Richard E. Handbook for Doctor of Ministry Projects: An Approach to Structured Observation of Ministry. Lanham, MD: University Press of America, 1984.

Davis, Henry Grady. Design for Preaching. Philadelphia, PA: Fortress Press, 1985.

Davis, Ken. How to Speak to Youth-and Keep Them Awake at the Same Time. Grand Rapids, MI: Zondervan, 1996.

. Secrets of Dynamic Communication. Grand Rapids, MI: Zondervan, 1991.

Dettoni, John M. "Psychology of Adulthood." In The Christian Educator's Handbook on Adult Education, edited by Kenneth O. Gangel and James C. Wilhoit, 77-87. Wheaton, IL: Victor Books, 1993.

Dodd, C. H. The Apostolic Preaching and Its Developments. New York: Harper and Bros., 1949.

Doubek, William J. P., III. A LCMS Lay Homiletic. D.Min thesis, Aquinas Institute of Theology, 2000.

Duduit, Michael, ed. Handbook of Contemporary Preaching. Nashville, TN: Broadman Press, 1992.

Dyman, Victor V. "Holistic Approach to Preaching: A Training Program for Lay Speakers of Manhattan Seventh-day Adventist Church." D.Min. thesis, Andrews University, 2008.

Edwards, Rex. A New Frontier: Every Believer a Minister. Mountain View, CA: Pacific Press, 1979.

Elliott, Mark Barger. Creative Styles of Preaching. Louisville, KY: Westminister John - Knox Press, 2000.

Encyclopedia Britannica. "The Synagogue." http:www.britannica.com/ebi/article-203307 (accessed April 11, 2009).

Eusebius. Quoted in John Stott, Between Two Worlds: The Art of Preaching in the Twentieth Century. Grand Rapids, MI: Eerdmans, 1982. 
. Ecclesiastical History of Eusebius Pamphilus. Translated by C. F. Cruse.

London: G. Bell and sons, 1889.

Faivre, Alexandre. The Emergence of the Laity in the Early Church. Translated by David Smith. New York: Paulist Press, 1990.

Fant, Clyde E. Bonhoeffer: Worldly Preaching. Nashville, TN: T. Nelson, 1975.

Fant, Clyde E., and William M. Pinson, eds. 20 Centuries of Great Preaching. 13 vols. Waco, TX: Word Books, 1971.

Fisher, James, and Ronald Podeschi. "From Lindeman to Knowles: A Change in Vision." International Journal of Lifelong Education 8, no. 4 (October-December 1989): $345-53$.

Flannery, Clyde C. "A Bible Skills Workshop." D.Min. thesis, Christian Theological Seminary, 1976.

Foley, Nadine, ed. Preaching and the Non-Ordained. Collegeville, MN: Liturgical Press, 1983.

Fortney, William Boyd. "Communicating God's Character to Children." Th.M. project, Dallas Theological Seminary, 1973.

Galli, Mark, and Craig B. Larson. Preaching that Connects. Grand Rapids, MI: Zondervan, 1994.

Gangel, Kenneth O., and James C. Wilhoit, eds. The Christian Educator's Handbook on Adult Education. Wheaton, IL: Victor Books, 1993.

Gibbs, Mark, and T. Ralph Morton. God's Frozen People. Philadelphia, PA:

Westminister Press, 1965.

Gowan, Donald E. Reclaiming the Old Testament for the Christian Pulpit. Atlanta, GA: John Knox Press, 1980.

Grant, Reg, and John Reed. The Power Sermon. Grand Rapids, MI: Baker Books,1993.

Greenhaw, David M., and Ronald J. Allen, eds. Preaching in the Context of Worship. St. Louis, MO: Chalice Press, 2000.

Greidanus, Sidney. Preaching Christ from the Old Testament. Grand Rapids, MI: Eerdmans, 1999.

Griggs, Donald L. The Planning Game. Livermore, CA: Griggs Educational Service, 1971. 
Grimes, Howard. The Rebirth of the Laity. New York: Abingdon, 1962.

Gwyn, Douglas. "A School of the Prophets: Teaching Congregational Members to Preach." In Preaching in the Context of Worship, edited by David M. Greenhaw and Ronald J. Allen, 99-105. St. Louis, MO: Chalice Press, 2000.

Hamilton, Donald L. Homiletical Handbook. Nashville, TN: Broadman Press, 1992.

Hanson, Anthony Tyrrell. The Living Utterances of God: The New Testament Exegesis of the Old. London: Darton, Longman and Todd, 1983.

Heeg, Harmen. Word and Situation in Reformed Preaching. D.Min. thesis, Christian Theological Seminary, 1979.

Henry, Matthew. "Matthew Henry's Complete Commentary on the Whole Bible." BibleStudyTools.com. http://www.biblestudytools.com/commentaries/matthewhenry-complete/Deuteronomy/4.html?p=3 (accessed May 20, 2010).

Henson, Hensley. Church and Parson in England. London: Hodder \& Stroughton, 1927.

Home Missionary Dept., General Conference of Seventh-day Adventists. The Lay Preacher and His Work. Nashville, TN: Southern Publishing Association, 1940. . Lay Preacher's Manual: Instructions in the Principles and Methods of Public Evangelism. Nashville, TN: Southern Publishing Association, 1934.

Honeycutt, Frank G. Preaching to Skeptics and Seekers. Nashville, TN: Abingdon Press, 2001.

Howe, Reuel L. Partners in Preaching: Clergy and Laity in Dialogue. New York: Seabury Press, 1967.

Hubbard, Robert L., Jr., Robert K. Johnston, and Robert P. Meye, eds. Studies in Old Testament Theology. Dallas, TX: Word Publishers, 1992.

Hucks, Willie Edward, III. "A Preaching Program to Instill Social Consciousness in African-American Churches in Dallas/Fort Worth, Texas." D.Min. thesis, Andrews University, 2006.

Hull, Bill. The Disciple-Making Pastor. Grand Rapids, MI: Baker Books, 2007.

Hull, John H. E. The Holy Spirit in the Acts of the Apostles. Cleveland, OH: World Publishing, 1968. 
Irenaeus. "Irenaeus against Heresies." In The Ante-Nicene Fathers, edited by Alexander Roberts, James Donaldson, and Arthur C. Coxe, 1:462-567. Grand Rapids, MI: Eerdmans, 1956.

Jabusch, Willard F. The Person in the Pulpit. Nashville, TN: Abingdon Press, 1980.

Jeter, Joseph R, II, and Ronald J. Allen. One Gospel, Many Ears: Preaching for Different Listeners in the Congregation. St. Louis, MO: Chalice Press, 2002.

Juarez, Julio I. "A Program to Improve Bible Study and Prayer in the Humboldt Park Hispanic Seventh-day Adventist Church." D.Min. thesis, Andrews University, 2001.

Kienzle, Beverly Mayne, and Pamela J. Walker, eds. Women Preachers and Prophets Through Two Millennia of Christianity. Berkeley, CA: University of California Press, 1998.

The KJV Old Testament Hebrew Lexicon. "Dabar." http://www.biblestudytools.com/ lexicons/hebrew/kjv/dabar.html (accessed March 2, 1999).

. "Qara'." http://www.biblestudytools.com/lexicons/hebrew/kjv/qara.html (accessed March 2, 1999).

."Shama'." http://www.biblestudytools.com/lexicons/hebrew/kjv/shama.html (accessed March 2, 1999).

The KJV New Testament Greek Lexicon. "Anaggello.” http://www.biblestudytools.com/ lexicons/greek/kjv/anaggello.html (accessed March 2, 1999).

. "Euaggelizo." http://www.biblestudytools.com/lexicons/greek/kjv/ euaggelizo.html (accessed March 2, 1999).

Knight, George R. Millennial Fever and the End of the World: A Study of Millerite Adventism. Boise, ID: Pacific Press, 1993.

Knowles, Malcolm S. Informal Adult Education. New York: Association Press, 1950. The Modern Practice of Adult Education: Andragogy Versus Pedagogy. Chicago, IL: Association Press/Follett, 1970.

Larson, Rebecca. Daughters of Light. New York: Knopf, 1999.

Latourette, Kenneth Scott. A History of the Expansion of Christianity. 7 vols. New York: Harper and Bros., 1937-45. 
Lawless, Elaine J. Women Preaching Revolution. Philadelphia, PA: University of Pennsylvania Press, 1996.

Lawrence, Randee Lipson, ed. Artistic Ways of Knowing: Expanded Opportunities for Teaching and Learning. New Directions for Adult and Continuing Education 107. San Francisco, CA: Jossey-Bass, 2005.

Lewis, Ralph L., with Gregg Lewis. Inductive Preaching: Helping People Listen. Westchester, IL: Crossway Books, 1983. . Learning to Preach Like Jesus. Westchester, IL: Crossway Books, 1989.

Linberg, Edwin C:" "An Examination of the Role of the Clergy as an Enabler of the Development and Growth of the Ministry of the Laity." D.Min. thesis, Claremont School of Theology, 1975.

Lischer, Richard. A Theology of Preaching. Nashville, TN: Abingdon Press, 1981.

Lischer, Richard, ed. The Company of Preachers: Wisdom on Preaching, Augustine to the Present. Grand Rapids, MI: Eerdmans, 2002.

Long, Thomas G. Preaching and the Literary Forms of the Bible. Philadelphia, PA: Fortress Press, 1996.

. The Witness of Preaching. Louisville, KY: Westminister/John Knox Press, 1989.

Loscalzo, Craig A. Preaching Sermons That Connect. Downers Grove, IL: InterVarsity Press, 1992.

Lowry, Eugene L. The Sermon. Nashville, TN: Abingdon Press, 1997.

Martyr, Justin. Apology. With a Foreword by Basil L. Gildersleeve. New York: American Book Co., 1904.

. "The First Apology of Justin." In The Ante-Nicene Fathers, edited by Alexander Roberts, James Donaldson, and Arthur C. Coxe, 1:157-187. Grand Rapids, MI: Eerdmans, 1956.

Massey, James Earl. The Burdensome Joy of Preaching. Nashville, TN: Abingdon Press, 1998.

Mathews, Alice. Preaching that Speaks to Women. Grand Rapids, MI: Baker Academic, 2003. 
Mawhinney, Bruce. Preaching with Freshness. Eugene, OR: Harvest House Publishers, 1991.

McCarthy, Bernice, and Carol Keene. About Learning. Barrington, IL: Excell, 1996.

McCurley, Foster R Wrestling with the Word: Christian Preaching from the Hebrew Bible. Valley Forge, PA: Trinity Press International, 1996.

McDill, Wayne. The 12 Essential Skills for Great Preaching. Nashville, TN: Broadman \& Holman Publishers, 1994.

McFague, Sallie. Speaking in Parables: A Study in Metaphor and Theology. Philadelphia, PA: Fortress Press, 1975.

Miller, Calvin. The Empowered Communicator. Nashville, TN: Broadman \& Holman, 1994. . Marketplace Preaching. Grand Rapids, MI: Baker Books, 1995.

Mitchell, Henry H. Celebration and Experience in Preaching. Nashville, TN: Abingdon Press, 1990.

Mnich, Michael A. "Preaching by Discovery: A Training Program to Help Lay Speakers Develop a Style of Preaching that Motivates to Action." D.Min. thesis, Andrews University, 2001.

Morris, Derek John. "Listening to the Listener." D.Min. thesis, Gordon-Conwell Theological Seminary, 1998.

Mulder, David P. Narrative Preaching: Stories from the Pulpit. St. Louis, MO: Concordia Publishing House, 1996.

Mulligan, Mary A., and Ronald J. Allen. Make the Word Come Alive: Lessons from Laity. St. Louis, MO: Chalice Press, 2005.

Myers, William R. Research in Ministry: A Primer for the Doctor of Ministry Program. Chicago, IL: Exploration Press, 1997.

The NAS New Testament Greek Lexicon. "Kerusso." http://www.biblestudytools.com/ lexicons/greek/nas/kerusso.html (accessed March 2, 1999).

Neill, Stephen Charles and Hans-Ruedi Weber, eds. The Layman in Christian History: A Project of the Department on the Laity of the World Council of Churches. Philadelphia, PA: Westminister Press, 1963. 
The New International Dictionary of New Testament Theology. Edited by Colin Brown. Grand Rapids, MI: Zondervan, 1979. S.v. "Laity."

O'Connor, William R. The Layman's Call. New York: P. J. Kenedy \& Sons, 1942.

O'Day, Gail R., and Thomas G. Long, eds. Listening to the Word. Nashville, TN: Abingdon Press, 1993.

O'Gara, James., ed. The Layman in the Church. New York: Herder and Herder, 1962.

Osborn, Ronald E. Folly of God: The Rise of Christian Preaching. Vol. 1 of A History of Christian Preaching. St. Louis, MO: Chalice Press, 1999.

Ottati, Frank. "A Training Seminar for Preaching: Developing Effective Preaching Skills." D.Min. dissertation, Andrews University, 1998.

Overstreet, R. Larry: Biographical Preaching. Grand Rapids, MI: Kregel, 2001.

Palmer, Phoebe. "The Great Army of Preaching Women." In The Company of Preachers: Wisdom on Preaching, Augustine to the Present, edited by Richard Lischer, 92. Grand Rapids, MI: Eerdmans, 2002.

Parachini, Patricia A. Lay Preaching: State of the Question. Collegeville, MN: Liturgical Press, 1999.

Pattison, T. Harwood. The History of Christian Preaching. Philadelphia, PA: American Baptist Publishing Society, 1903.

Piper, John. The Supremacy of God in Preaching. Grand Rapids, MI: Baker Book House, 1990.

Proctor, Samuel D. The Certain Sound of the Trumpet. Valley Forge, PA: Judson Press, 1994.

Pujic, Miroslav. "A Disciple-Making Strategy to Reach the Emerging Postmodern Generation." D.Min. thesis, Andrews University, 2005.

Putz, Luis Joseph. The Modern Apostle. Chicago, IL: Fides Publishers, 1957.

Quicke, Michael J. 360-Degree Preaching. Grand Rapids, MI: Baker Academic, 2003.

Richards, Larry, and Gilbert R. Martin. Lay Ministry: Empowering the People Of God. Grand Rapids, MI: Ministry Resources Library, 1988.

Richardson, Alan. A Dictionary of Christian Theology. Philadelphia, PA: Westminster Press, 1969. 
Robinson, Haddon W. Biblical Preaching: The Development and Delivery of Expository Messages. Grand Rapids, MI: Baker Book House, 1980.

Robinson, Wayne B., ed. Journeys Toward Narrative Preaching. New York: Pilgrim Press, 1990.

Rowthorn, Anne. The Liberation of the Laity. Wilton, CT: Morehouse-Barlow, 1986.

Schillebeeckx, Edward. "The Right of Every Christian to Speak in the Light of Evangelical Experience 'In the Midst of Brothers and Sisters." In Preaching and the Non-Ordained: An Interdisciplinary Study, edited by Nadine Foley, 11-39. Collegeville, MM: Liturgical Press, 1983.

Schneiders, Sandra. "New Testament Foundations for Preaching by the Non-Ordained." In Preaching and the Non-Ordained: An Interdisciplinary Study, edited by Nadine Foley, 60-90. Collegeville, MN: Liturgical Press, 1983.

Schurch, Maylan. Help! I've Been Asked To Preach: Don't Panic. Here's Practical Help to Keep Your Sermon from Sinking. Hagerstown, MD: Review and Herald, 2007.

Shaddix, Jim. The Passion Driven Sermon. Nashville, TN: Broadman \& Holman, 2003.

Smyth, Charles. The Art of Preaching. London: S.P.C.K., 1953.

Stagg, Evelyn, and Frank Stagg. Woman in the World of Jesus. Philadelphia, PA: Westminister Press, 1978.

Stanfield, Vernon L., Paul E. Sangster, and Clarence S. Roddy. Homiletics. Grand Rapids, MI: Baker Book House, 1974. .

Stewart, Carlyle Fielding. Joy Songs, Trumpet Blasts, and Hallelujah Shouts! Lima, OH: CSS Publishing Co., 1997.

Stickland, Mike. Heralds of God's Word: Lay Preaching Seminar Textbook. Silver Spring, MD: Ministerial Association, General Conference of Seventh-day Adventists, 1998.

. Heralds of God's Word: Lay Preaching Seminar Workbook. Silver Spring, MD: Ministerial Association, General Conference of Seventh-day Adventists, 1998.

Stott, John. Between Two Worlds: The Art of Preaching in the Twentieth Century. Grand Rapids, MI: Eerdmans, 1982. 
Strong, James. "A Concise Dictionary of the Words in the Greek New Testament." In The Hebrew-Greek Key Study Bible, edited by Spiros Zodhiates, 2379.

Chattanooga, TN: AMG Publishers, 1991.

. "A Concise Dictionary of the Words in the Hebrew Bible." In The HebrewGreek Key Study Bible, edited by Spiros Zodhiates, 1604-10. Chattanooga, TN: AMG Publishers, 1991.

Swidler, Leonard. Women in Judaism: The Status of Women in Formative Judaism. Metuchen, NJ: Scarecrow Press, 1976.

Tavard, George H. The Church, the Layman, and the Modern World. New York: MacMillan, 1959.

Taylor, Barbara Brown. The Preaching Life. Cambridge, MA: Cowley Publications, 1993.

Taylor, Isaac. Ultimate Civilization, and Other Essays. London: Bell and Daldy, 1860.

"The Teaching of the Twelve Apostles." In The Ante-Nicene Fathers, edited by Alexander Roberts, James Donaldson, and Arthur C. Coxe, 7:369-384. Grand Rapids, MI: Eerdmans, 1956.

Telford, John. A History of Lay Preaching in the Christian Church. London: Charles H. Kelly, 1897.

Tertullian. "Apology." In The Ante-Nicene Fathers, edited by Alexander Roberts, James Donaldson, and Arthur C. Coxe, 3:17-60. Grand Rapids, MI: Eerdmans, 1956.

Thielen, Martin. Getting Ready for Sunday's Sermon. Nashville, TN: Broadman Press, 1990.

Thompson, James W. Preaching Like Paul: Homiletical Wisdom for Today. Louisville, KY: Westminister John Knox Press, 2001.

Troeger, Thomas H. Imagining a Sermon. Nashville, TN: Abingdon Press, 1990.

Troeger, Thomas H., and H. Edward Everding Jr. So That All Might Know: Preaching That Engages the Whole Congregation. Nashville, TN: Abingdon Press, 2008.

Tupas, Archibald P. "A Biblically Based Instruction Program in Preaching for Local Church Elders and Lay Preachers in the Philippines." D.Min. project report, Andrews University, 1985.

Turner, R. Edward. Proclaiming the Word: The Concept of Preaching in the Thought of Ellen G. White. Berrien Springs, MI: Andrews University Press, 1980. 
Van Seters, Arthur, ed. Preaching as a Social Act. Nashville, TN: Abingdon Press, 1988.

Vitrano, Steven. How to Preach: A Practical Guide to Better Sermons. Hagerstown, MD: Review and Herald, 1991.

. Preaching the Four Faces of Salvation. Nampa, ID: Pacific Press, 2000.

. So You're Not A Preacher! A Lay Leader's Guide for Sermon Preparation.

Washington, DC: Review and Herald, 1977.

von Campenhausen, Hans. Ecclesiastical Authority and Spiritual Power in the Church of the First Three Centuries. Stanford, CA: Stanford University Press, 1969.

Wardlaw, Don M. "Preaching as the Interface of Two Social Worlds: The Congregation as Corporate Agent in the Act of Preaching." In Preaching as a Social Act, edited by Arthur Van Seters. Nashville, TN: Abingdon Press, 1988.

Weiss, Carol H. Evaluation Research: Methods for Assessing Program Effectiveness. Englewood Cliffs, NJ: Prentice-Hall, 1972.

Wells, C. Richards, and A. Boyd Luter. Inspired Preaching: A Survey of Preaching Found in the New Testament. Nashville, TN: Broadman \& Holman, 2002.

White, Ellen G. The Acts of The Apostles. Washington, DC: Review and Herald, 1970. . A Call To Medical Evangelism and Health Education. Nashville, TN:

Southern Publishing Association, 1954.

. Christ's Object Lessons. Washington, DC: Review and Herald, 1941.

. Evangelism. Washington, DC: Review and Herald, 1946.

. Gospel Workers: Instruction for All Who are "Laborers Together with God." Washington, DC: Review and Herald, 1945.

. The Great Controversy Between Christ and Satan. Mountain View, CA:

Pacific Press, 1911.

. Instruction for Effective Christian Service. Washington, DC: Home

Missionary Dept. of the General Conference of Seventh-day Adventists, 1947.

. Instruction for Effective Christian Service. Washington, DC: Review and

Herald, 1983. . Ministry of Healing. Mountain View, CA: Pacific Press, 1942. 

1971.

A Study Guide to Christian Service. Washington, DC: Review and Herald, . Testimonies for the Church. 9 vols. Mountain View, CA: Pacific Press, 1948. ., to Brethren and Sisters in Nashville and in Madison, 15 October 1906. Letter 318, 1906. Center for Adventist Research. Andrews University, Berrien Springs, MI.

., to J. E. White and Emma White, 10 September 1875. Letter 32, 1875. Center for Adventist Research. Andrews University, Berrien Springs, MI.

. The Voice in Speech and Song. Boise, ID: Pacific Press, 1988.

Wiersbe, Warren W. Preaching \& Teaching with Imagination. Wheaton, IL: Victor Books, 1994.

Willhite, Keith, and Scott M. Gibson, eds. The Big Idea of Biblical Preaching. Grand Rapids, MI: Baker Books, 1998.

Williams, George H. "The Ancient Church, AD.30-313." In The Layman in Christian History: A Project of the Department on the Laity of the World Council of Churches, edited by Stephen Charles Neill and Hans-Ruedi Weber, 28-56. Philadelphia, PA: Westminister Press, 1963.

Willimon, William H. Acts: A Bible Commentary for Teaching and Preaching. Atlanta: John Knox, 1988.

. Peculiar Speech: Preaching to the Baptized. Grand Rapids, MI: Eerdmans, 1992.

Wilson, Paul Scott. A Concise History of Preaching. Nashville, TN: Abingdon Press, 1992.

Worley, Robert C. Preaching and Teaching in the Earliest Church. Philadelphia, PA: Westminister Press, 1967.

Wyclif, John. Contra Fratres. Quoted in Clyde E. Fant and William M. Pinson, eds., 20 Centuries of Great Preaching. 13 vols. Waco, TX: Word Books, 1971.

Yount, William R. Called to Reach: Equipping Cross-Cultural Disciplers. Nashville, TN: B \& H Academic, 2007.

. Called To Teach: An Introduction to the Ministry of Teaching. Nashville, TN: Broadman \& Holman Publishers, 1999. 
. Research Design and Statistical Analysis for Christian Ministry. Fort Worth, TX: W. R. Yount, 2006.

Zodhiates, Spiros. "Lexical Aids to the New Testament." In The Hebrew-Greek Key Study Bible, edited by Spiros Zodiates, 1727. Chattanooga, TN: AMG Publishers, 1991.

\section{Articles}

Beale, G. K. "Did Jesus and His Followers Preach the Right Doctrine from the Wrong Texts?" Themelius 14, no. 3 (Spring 1989): 91-96.

Bruce, David. "The Synagogue and Christ's Ministry." Expositor 9 (April 1896): 132.

Lieb, Stephen. "Principles of Adult Learning." Vision (Fall 1991): 117-132.

Mehl, L. Guy. "Nurturing and Mythus Bearing in Clergy Work Motivation." Journal of Religion and Health 18, no. 1 (January 1979): 29-37.

Miller, Calvin, and Derrick Morris. "A Look at Marketplace Preaching: An Interview with Calvin Miller. Ministry Magazine 71 (November 1999): 13-14.

Monckres, Peter R. "Lay Sermons: The Power and the Glory." Christian Ministry 10 (March 1979): 31-33.

Olson, Dennis T. "Rediscovering Lost Treasure: Forgotten Preaching Texts of the Old Testament." Journal for Preachers 13, no. 4 (1990): 2-10.

Skudlarek, William. “Lay Preaching and the Liturgy.” Worship 56 (May 1982): 500-506.

Taylor, Nancy. "The Work of The People: From Silence to Faith Proclamation." The Chicago Theological Seminary Register 87 (1997): 10-42.

Tyson, Joseph B. "The Emerging Church and the Problem of Authority in the Book of Acts." Interpretation 23, no. 2 (April 1988): 132-45.

Willimon, William H., and Robert L. Wilson. "Give Us Leaders, Not Managers." Adventist Review, January 24, 1990, 8-10.

\section{Other Sources}

Denslow, Kenneth. Personal Interview. September 10, 2006. 
Dybdall, John. Class Lectures. "Spiritual Formation: Considerations for Ministers." Andrews University Theological Seminary, July 2006.

Nelson, Dwight. Class Lectures. "Disciplines and Practices in Sermon Preparation." Andrews University Theological Seminary, June 2006.

Small, Clarence. Personal Interview. July 17, 2006.

Vyhmeister, Nancy. Class Outline "CHMN 610: Teaching Ministry." Andrews University Theological Seminary, 1992.

Wright, Walter. Personal Interview. February 22, 2007. 
VITA 
VITA

Name: Leeroy Maloney Coleman

Place of Birth: Jamaica, West Indies

Spouse: Lorraine Olivia Legg

Children: Chiblie, Casey \& Caribe

\section{Education:}

2011 D. Min. Preaching, Andrews University Theological Seminary

1985 M.Div. Andrews University Theological Seminary

1982 B.A. Theology \& Counseling, Andrews University

\section{Credentials:}

1988

Ordination, Illinois Conference of S.D.A. Church

1992

Counseling Certification, American Association of Christian Counselors (AACC)

2011

Clinical Pastoral Education (CPE), Vitas Hospice Care

\section{Ministry/Professional Experience}

2011-Present

2009-Present

2007-2009

1992-2007

2006-2007

1985-1992

1984-1992

1984-1985
Sr. Pastor, Shiloah SDA Church, Chicago, IL

Bereavement Specialist/Chaplain, Vitas Hospice Care, IL

Senior Pastor, Kansas Ave. SDA Church, Riverside, CA

Pastor, Goshen SDA Church, Chicago, IL

Pastor, Bolingbrook SDA Church, Bolingbrook, IL

Pastor, New Jerusalem SDA Church, Bradley, IL

Associate Director of Stewardship, Illinois Conference

Youth Pastor, Beverly Hills SDA Church, Chicago, IL 


\section{VITA}

Name: Leeroy Maloney Coleman

Place of Birth: Jamaica, West Indies

Spouse: Lorraine Olivia Legg

Children: Chiblie, Casey \& Caribe

Education: 2011 D. Min. Preaching, Andrews University Theological Seminary

1985 M.Div. Andrews University Theological Seminary

1982 B.A. Theology \& Counseling, Andrews University

Credentials:

1988

1992

Counselors (AACC)

2011
Ordination, Illinois Conference of S.D.A. Church

Counseling Certification, American Assoc. of Christian

Clinical Pastoral Education (CPE), Vitas Hospice Care

\section{Ministry/Professional Experience}

2011 - Present

2009- Present

2007- 2009

$1992-2007$

2006-2007

1985- 1992

1984- 1992

1984- 1985
Sr. Pastor, Shiloah SDA Church, Chicago, Illinois

Bereavement Specialist/Chaplain, Vitas Hospice Care, IL.

Sr. Pastor, Kansas Ave SDA Church, Riverside, CA.

Pastor, Goshen SDA Church, Chicago, IL.

Pastor, Bolingbrook SDA Church, Bolingbrook, IL.

Pastor, New Jerusalem SDA Church, Bradley, IL.

Assoc. Director of Stewardship, Illinois Conf. of SDA Ch.

Youth Pastor, Beverly Hills SDA Church, Chicago, IL 